WSRC-TR-2002-00288, Rev. 0

Distribution Category: Unlimited

Keywords: Zeolite, zeolite aging, vitrification, sludge batch 3

Retention: Permanent

\title{
IMPACT OF ZEOLITE TRANSFERRED FROM TANK 19F TO TANK 18F ON DWPF VITRIFICATION OF SLUDGE BATCH 3 (U)
}

C. M. Jantzen, R.F. Swingle, and F.G. Smith

September 18, 2003

Approved by:

W.E. Stevens, Research Manager

Waste Processing Technology

Westinghouse Savannah River Company

Savannah River Site

Savannah River Technology Center

Aiken, SC 29808

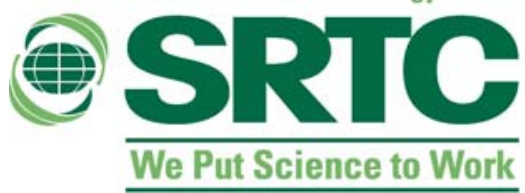

PREPARED FOR THE U.S. DEPARTMENT OF ENERGY UNDER CONTRACT NO. DE-AC09-96SR18500 
This document was prepared in conjunction with work accomplished under Contract No. DE-AC09-96SR18500 with the U. S. Department of Energy.

\section{DISCLAIMER}

This report was prepared as an account of work sponsored by an agency of the United States Government. Neither the United States Government nor any agency thereof, nor any of their employees, makes any warranty, express or implied, or assumes any legal liability or responsibility for the accuracy, completeness, or usefulness of any information, apparatus, product or process disclosed, or represents that its use would not infringe privately owned rights. Reference herein to any specific commercial product, process or service by trade name, trademark, manufacturer, or otherwise does not necessarily constitute or imply its endorsement, recommendation, or favoring by the United States Government or any agency thereof. The views and opinions of authors expressed herein do not necessarily state or reflect those of the United States Government or any agency thereof.

This report has been reproduced directly from the best available copy.

Available for sale to the public, in paper, from: U.S. Department of Commerce, National Technical Information Service, 5285 Port Royal Road, Springfield, VA 22161, phone: (800) 553-6847, fax: (703) 605-6900

email: orders@ntis.fedworld.gov

online ordering: http://www.ntis.gov/help/index.asp

Available electronically at http://www.osti.gov/bridge

Available for a processing fee to U.S. Department of Energy and its contractors, in paper, from: U.S. Department of Energy, Office of Scientific and Technical Information, P.O. Box 62, Oak Ridge, TN 37831-0062,

phone: (865)576-8401,

fax: (865)576-5728

email: $\underline{\text { reports@ adonis.osti.gov }}$ 
WSRC-TR-2002-00288, Rev. 0

Distribution Category: Unlimited

Keywords: Zeolite, zeolite aging, vitrification, sludge batch 3

Retention: Permanent

\section{IMPACT OF ZEOLITE TRANSFERRED FROM TANK 19F TO TANK 18F ON DWPF VITRIFICATION OF SLUDGE BATCH 3 (U)}

C. M. Jantzen, R.F. Swingle, and F.G. Smith

Publication Date: September 18, 2003

Westinghouse Savannah River Company

Savannah River Site
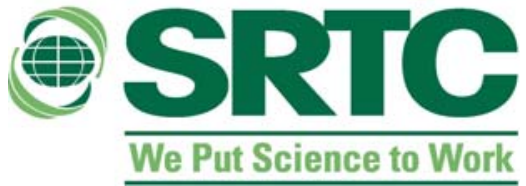

PREPARED FOR THE U.S. DEPARTMENT OF ENERGY UNDER CONTRACT NO. DE-AC09-96SR18500 


\section{Approvals}

C. M. Jantzen, Author, Immobilization Technology

Date

R.F. Swingle, Author, Waste Processing Technology

Date

F.G. Smith, Author, Immobilization Technology

Date

N.E. Bibler, Technical Reviewer, Immobilization Technology

Date

D.K. Peeler, Technical Reviewer, Immobilization Technology

Date

M. A. Rios-Armstrong, Reviewer, DWPF Process Engineering

Date

P.D. d’Entremont, Technical Reviewer, High Level Waste

Date

W.E. Stevens, Manager, Waste Processing Technology

Date

J. E. Occhipinti, Manager, DWPF Process Engineering

Date 


\section{EXECUTIVE SUMMARY}

The Defense Waste Processing Facility (DWPF) is planning to initiate vitrification of Sludge Batch \#3 (SB3) in combination with Sludge Batch \#2 (SB2), which is currently being processed, in the spring of 2004. The contents of Sludge Batch \#3 will be a mixture of the heel remaining from Sludge Batch \#1B in Tank 51H, sludge from Tank 7F (containing coal, sand, and sodium oxalate), and sludge materials from Tank 18F. The sludge materials in Tank 18F contain part of a mound of zeolitic material transferred there from Tank 19F. This mound was physically broken up and transfers were made from Tank 19F to Tank 18F for vitrification into SB3. In addition, the Savannah River High Level Waste Division (HLWD) has transferred excess Pu and Am/Cm materials to Tank 51H to be processed through the DWPF as part of SB3. Additional Pu material and a Np stream from the Canyons are also planned to be added to SB3 before processing of this batch commences at DWPF.

An assessment of the potential impacts of the zeolitic material on SB3 processing and glass product quality was requested by HLWD. This evaluation entailed the following:

- identification of the mound material as degraded (aged) IE-95 zeolite used in cesium recovery columns (CRCs) to remove cesium from the overheads of the SRS Evaporators in F-Area

- identification of the zeolite aging mechanism and impacts on sludge composition, processing, and sludge washing

- zeolite density and moisture content

- zeolite particle size distribution and potential impacts on the DWPF Hydragard $^{\circledR}$ sludge sampling system and representativeness of the sludge sample for DWPF process control

- impacts, if any, of excess zeolite on sludge waste loading and glass processing

- anion content of the zeolite minerals in the mound to examine any adverse chemical composition impacts on DWPF glass composition and/or off-gas generation

The primary objective of this task was to assess the impacts of the excess zeolite mound material in Tank 19F on the predicted glass and processing properties of interest when the zeolite becomes part of SB3. From the amounts of the Tank 19F heel that could have been transferred (in gallons) to Tank $18 \mathrm{~F}$ and the density of the zeolite mound measured in September 2002, a maximum of 48,120 kgs of sodium aluminosilicate rich zeolite from the Tank 19F mound may have been transferred to Tank 18F and potentially to SB3 if the transfers of solids from Tank $19 \mathrm{~F}$ to Tank $18 \mathrm{~F}$ were homogeneous. However, calculations of the residual zeolite in Tank 19F indicate that only 14,338 kgs of zeolite were transferred indicating that the salt and sludge solids in the mound in Tank $19 \mathrm{~F}$ were 
transferred to Tank $18 \mathrm{~F}$ selectively over the zeolite solids. This is in agreement with the fact that only $24,818 \mathrm{kgs}$ of zeolite were discharged to Tank 19F over its lifetime of zeolite receipt. The 14,338 kgs transferred to Tank $18 \mathrm{~F}$ converts to approximately 3.8 $\mathrm{wt} \%$ of the proposed SB3 constituents if all of the zeolite material in Tank 18F is blended into SB3.

The two potential impacts of the Tank 19F zeolite mound on DWPF processing relates to (1) the Hydragard ${ }^{\circledR}$ samples taken for determination of the acceptability of a macrobatch of DWPF feed and (2) the achievable waste loading. An additional impact that may affect processing of SB3 and/or the evaporation of SB3 washwater relates to the liberation of $\mathrm{SiO}_{2}$ from the zeolite to the sludge when it aged from chabazite and erionite (IE-95 constituents) to the cancrinite/sodalite phases currently found in the Tank 19F mound.

In terms of the Hydragard ${ }^{\circledR}$ sampling of SB3 feeds for DWPF SME process control:

- the larger zeolite particles found in Tank 19F (average particle size of $500 \mu \mathrm{m})$ are too large to pass through the sampling valve and may plug the valve unless they are size reduced during subsequent transfers, homogenization, or processing

- the DWPF sampling system may not be capable of obtaining a representative sample of sludge containing zeolite if the particle size is not size reduced during subsequent transfers, homogenization, or processing

- sampling could miss an estimated $60 \%$ of the material causing misbatching of the feeds to the DWPF if the particle size is not size reduced during subsequent transfers, homogenization, or processing

- $\quad$ zeolite must be further degraded (particle size reduced) before Hydragard ${ }^{\circledR}$ sampling can be considered accurate for DWPF process control if the particle size is not size reduced during subsequent transfers, homogenization, or processing

The potential effects of the large size of the zeolite particles found in the Tank 19F solids, as reported in this study, are considered minimal for processing of SB3 in DWPF. This conclusion is based on recent sieve analyses of Tank $51 \mathrm{H}$ sludge after receipt from Tank $18 \mathrm{~F}$ which indicate that only $0.04 \mathrm{wt} \%$ particulates over $38 \mu \mathrm{m}$ are present in the sludge. These particulates appear to be coal and not zeolite. The sieve analyses indicate that the zeolite that was transferred may have degraded in size during all the tank homogenization and transfers if the sample that was sieved was representative of the tank contents. Moreover, recent analyses of Tank $18 \mathrm{~F}$ indicate that the heel remaining in Tank $18 \mathrm{~F}$ is enriched in silica, ${ }^{*}$ presumably zeolite, indicating that not all the zeolite from Tank $18 \mathrm{~F}$ was transferred to SB3. The zeolite heel in Tank 18F will only become

\footnotetext{
* Jonathan Thomas, personnel communication September 16, 2003.
} 
problematic for DWPF processing if the contents of Tank 18F ever become feed for subsequent DWPF feed.

The second potential impact on DWPF processing will be the ability to achieve higher waste loadings by $\sim 0.5-2.0 \mathrm{wt} \%$. In order to have a $1: 1$ correlation of the calculated waste loadings with and without zeolite present, comparisons to earlier calculations were made based on Frits 320, 165, and 200. The predicted glass properties at the property acceptable region (PAR) demonstrates the following:

- the maximum waste loading with the zeolite mound material present is consistently higher than the maximum waste loading without the zeolite mound material present

- $\quad$ the maximum waste loadings for SB3 without zeolite was 37-37.5 wt\% with Frit 320 depending on the sludge scenario being considered

- $\quad$ the maximum waste loadings for SB3 with zeolite was 0.5-2 wt\% waste loading higher (37.5-39 wt\%) with Frit 320 regardless of the sludge scenario being considered

- the maximum waste loading is always limited by the new liquidus temperature $\left(\mathrm{T}_{\mathrm{L}}\right)$ of the glass for the sludge scenarios examined in this study

- the new $T_{L}$ in turn is driven by the amount of sludge components such as $\mathrm{Fe}_{2} \mathrm{O}_{3}, \mathrm{NiO}$, and $\mathrm{MnO}$ present in the glass which is diluted by the increased $\mathrm{Na}_{2} \mathrm{O}, \mathrm{Al}_{2} \mathrm{O}_{3}$ and $\mathrm{Na}_{2} \mathrm{O}$ present in the zeolite material

- the zeolite (high sodium aluminosilicate) dilutes the sludge components in the glass and lowers the $\mathrm{T}_{\mathrm{L}}$ allowing for higher waste loadings

- the proposed glasses based on Frits 320, 165, and 200 are all durable regardless of sludge scenario and the presence of zeolite, this is consistent with new optimized frits developed for SB3

- the proposed glasses all have acceptable viscosities despite increased $\mathrm{Al}_{2} \mathrm{O}_{3}$ from the zeolite

- the viscosities with Frit 320 and Frit 165 are comparable

- $\quad$ the viscosities with Frit 200 are somewhat higher due to the $\mathrm{Al}_{2} \mathrm{O}_{3}$ content of the zeolite

- almost all the glasses violate the old $\mathrm{T}_{\mathrm{L}}$ model but all the glasses satisfy the new, more rigorous, $\mathrm{T}_{\mathrm{L}}$ model which has been implemented in DWPF

A third potential impact of the zeolite from Tank 19F in SB3 may affect the processing of SB3 and/or the evaporation of SB3 washwater:

- during zeolite aging of the IE-95 components chabazite and erionite to the sodalite/cancrinite mineral phases identified in the Tank 19F mound, 11 moles of $\mathrm{SiO}_{2}$ are liberated 
- the $\mathrm{SiO}_{2}$ liberated may be amorphous or may have reacted with excess $\mathrm{NaOH}$ in Tank 19F to form more sodalite in which case the conservative $14,338 \mathrm{kgs}$ of zeolite transferred to SB3 may be as high as 48,120 kgs

- the $\mathrm{SiO}_{2}$ liberated may be amorphous and may be entrained in or part of the SB3 sludge and may affect the rheology

- if the $\mathrm{SiO}_{2}$ liberated during zeolite conversion is amorphous it could become mobile during sludge washing causing the washwater to fail the newly implemented Si feed qualification limit that was implemented to avoid problematic aluminosilicate scale in the SRS evaporators

Other findings about the zeolite conversion mechanism via a process of Ostwald ripeining are discussed in the text and in the conclusions. In addition, cation-anion mass balance analyses of the zeolite mound and the IE-95 bulk and mineral densities were determined. A second type of ion exchange media (Decalso) also reportedly sent to Tank $19 \mathrm{~F}$ was analyzed. It was determined that the Decalso was an amorphous sodium aluminosilicate which degraded in $10 \mathrm{M}$ caustic to a sodium aluminosilicate gel. 


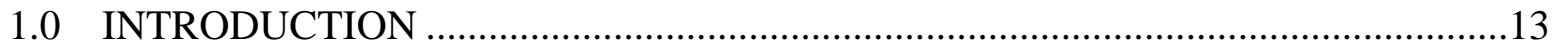

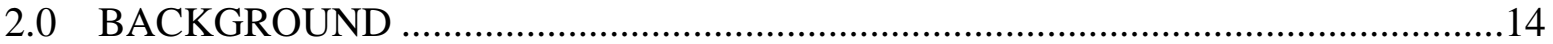

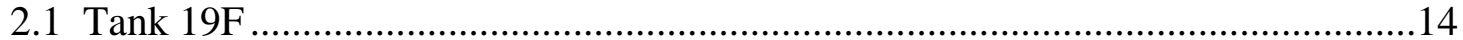

2.2 Tank 19F Transfers to Tank 18F ................................................................15

2.3 Zeolite Mineralogy ..........................................................................................19

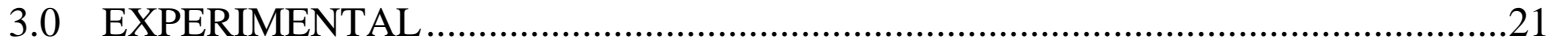

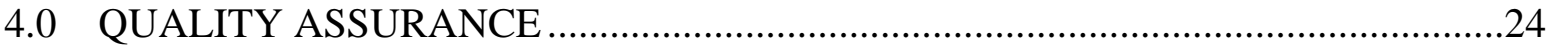

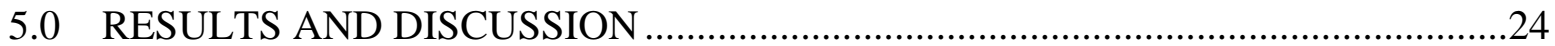

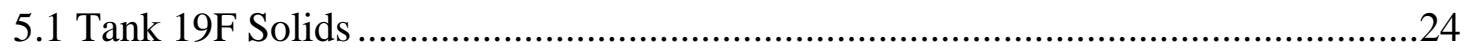

5.2 Unreacted IE-95 and Decalso Ion Exchange Media ...............................................28

5.3 Weight Loss and Particle Size of Tank 19F Solids Compared to IE-95 and

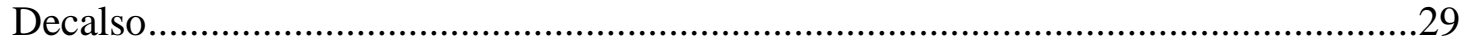

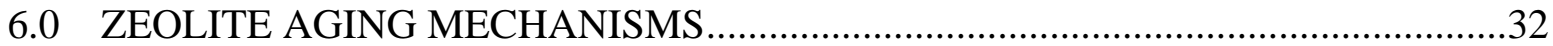

6.1 Tank 19F Sample Verification.........................................................................33

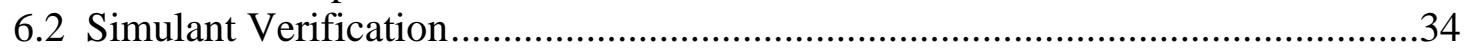

7.0 ZEOLITE PARTICLE SIZE AND IMPACTS ON HYDRAGARD ${ }^{\circledR}$

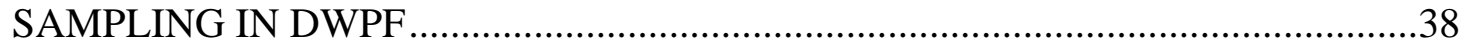

8.0 ZEOLITE AGING MECHANISM AND IMPACTS ON SLUDGE WASHING.........41

9.0 ZEOLITE SILICA CONTENT AND IMPACT ON GLASS PROCESSING IN DWPF

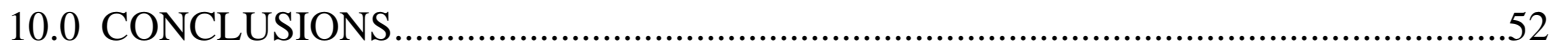

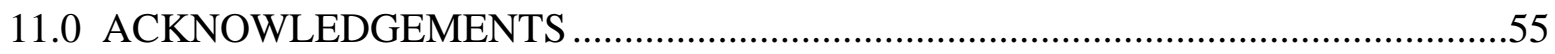

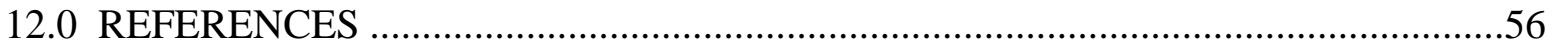




\section{LIST OF FIGURES}

Figure 1. X-ray Diffraction analysis of IE-95 performed in 1988 .................................20

Figure 2. Analysis of converted IE-95 from Tank $19 \mathrm{~F} .{ }^{12}$...........................................20

Figure 3. Part of the aluminosilicate framework in the structure of sodalite. ${ }^{17}$................21

Figure 4. Relationship between the atomic lattices of hexagonal, rhombohedral, and cubic crystal lattices of the sodalite/cancrinite minerals

Figure 5. Comparison of the weight loss upon calcining of the Tank 19F mound sample and unreacted ion exchange media (Decalso and IE-95).

Figure 6. Comparison of the particle size of the Tank 19F mound sample and unreacted ion exchange media (Decalso and IE-95).

Figure 7. Structural morphology of the transformation of chabazite and erionite to sodalite and cancrinite.

Figure 8. IE-95 before and after reaction with $10 \mathrm{M} \mathrm{NaOH}$ at $90^{\circ} \mathrm{C}$ for 2 days.................35

Figure 9. IE-95 after reaction with $10 \mathrm{M} \mathrm{NaOH}$ at $90^{\circ} \mathrm{C}$ for 7 days................................35

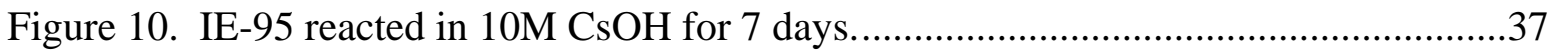

Figure 11. Decalso reacted in $10 \mathrm{M} \mathrm{NaOH}$ for 2 days. ................................................37

Figure 12. Particle size distributions of Tank19F mound material and CST....................40

Figure 13. Cumulative particle size distributions of Tank19F mound material and CST.

Figure 14. Increases in waste loading that can be achieved with various frits for SB3 due to the presence of zeolite. 


\section{LIST OF TABLES}

Table I Chemical Analyses in Element Wt\% for Tank 19F Solids dried at 105$115^{\circ} \mathrm{C}$.

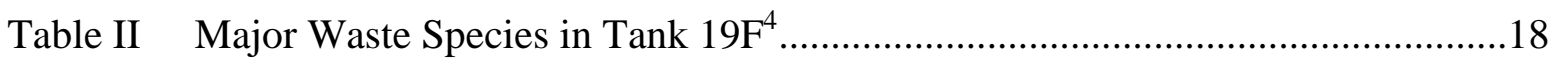

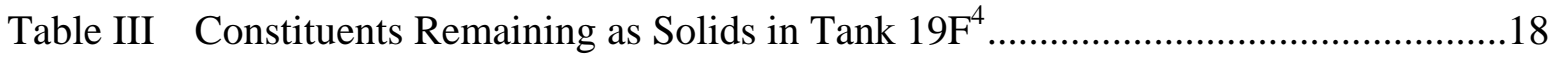

Table IV Structurally Related Sodalite and Cancrinite Mineral Phases ...........................22

Table V Anion Analysis of Tank 19F Solids..............................................................25

Table VI Mass Balance of Chemical Data from Table I and Table V ..............................26

Table VII Relative weight loss of Tank 19F Sample and Various Ion Exchange Media ..............................................................................................26

Table VIII Particle Size Analysis of Tank 19F Sample and Selected Ion Exchange

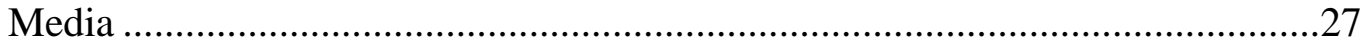

Table IX Composition of IE-95 and Decalso Ion Exchange Media Sent to Tank 19F.......28

Table X Conversion of IE-95 to Other Mineral Phases in the Presence of $\mathrm{NaOH}$

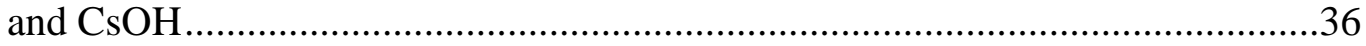

Table XI Nominal Individual Sludge Compositions (in wt\%, calcine oxide basis) ..........45

Table XII Nominal Sludge Calcine Compositions (Wt\%) for Various Blending Scenarios With and Without the Tank 19F/Tank 18F Zeolite Contribution .......46

Table XIII PAR Limits for Various Properties...............................................................48

Table XIV Summary of Predicted Properties at Maximum Allowable Waste Loading (using the new $\mathrm{T}_{\mathrm{L}}$ model and PAR limits).....................................................51 


\section{LIST OF ACRONYMS}

$\begin{array}{ll}\text { ADS: } & \text { Analytic Development Section of SRTC } \\ \text { CRC: } & \text { Cesium Recovery Column } \\ \text { CST: } & \text { Crystalline Silico Titanate } \\ \text { DOE: } & \text { United States Department of Energy } \\ \text { DWPF: } & \text { Defense Waste Processing Facility } \\ \text { ESPF: } & \text { Extended Sludge Processing Facility } \\ \text { IC: } & \text { Ion Chromotography } \\ \text { ICP-ES: } & \text { Inductively Coupled Plasma Emission Spectroscopy } \\ \text { HLWD: } & \text { High Level Waste Division } \\ \text { LHS: } & \text { Left Hand Side } \\ \text { MAR: } & \text { Measurement Acceptable Region } \\ \text { ML: } & \text { Mobile Laboratory of SRTC } \\ \text { OLS: } & \text { Ordinary Least Squares } \\ \text { PAR: } & \text { Property Acceptable Region } \\ \text { PCCS: } & \text { Product Composition Control System } \\ \text { PCT: } & \text { Product Consistency Test (ASTM C-1285) } \\ \text { PDF: } & \text { Powder Diffraction File } \\ \text { RBOF: } & \text { Receiving Basin for Off-site Fuel } \\ \text { RHS: } & \text { Right Hand Side } \\ \text { RRF: } & \text { Resin Regeneration Facility } \\ \text { SB1B: } & \text { Sludge Batch \#1B } \\ \text { SB2: } & \text { Sludge Batch \#2 } \\ \text { SB3: } & \text { Sludge Batch \#3 } \\ \text { SCF: } & \text { Shielded Cell Facility } \\ \text { SRS: } & \text { Savannah River Site } \\ \text { SRTC: } & \text { Savannah River Technology Center } \\ \text { TL: } & \text { Temperature of Liquidus } \\ \text { WL: } & \text { Waste Loading } \\ \text { WCP: } & \text { Waste Compliance Plan } \\ \text { WCS: } & \text { Waste Characterization System } \\ \text { WSRC: } & \text { Westinghouse Savannah River Company } \\ \text { XRD: } & \text { X-Ray Diffraction } \\ & \end{array}$




\title{
IMPACT OF ZEOLITE TRANSFERRED FROM TANK 19F TO TANK 18F ON DWPF VITRIFICATION OF SLUDGE BATCH 3 (U)
}

\author{
C. M. Jantzen, R.F. Swingle, and F.G. Smith \\ Savannah River Technology Center \\ Westinghouse Savannah River Company \\ Aiken, South Carolina 29808
}

\subsection{INTRODUCTION}

Approximately 130 million liters of high-level radioactive waste is currently stored in underground carbon steel tanks at the Savannah River Site (SRS) in Aiken, South Carolina. The Defense Waste Processing Facility (DWPF) began immobilizing these wastes in borosilicate glass in 1996. Currently, the radioactive glass is being produced as a "sludge-only" composition by combining washed high-level sludge with glass frit and melting. The glass is poured into stainless steel canisters that will eventually be disposed of in a permanent, geological repository.

Currently, the DWPF is processing Sludge Batch \#2 (SB2). The DWPF is planning to initiate vitrification of Sludge Batch \#3 (SB3) in combination with Sludge Batch \#2 (SB2), ${ }^{1}$ which is currently being processed, in Spring of 2004. The contents of Sludge Batch \#3 will be a mixture of the heel remaining from Sludge Batch \#1B in Tank $51 \mathrm{H}$, sludge from Tank 7F (containing coal, sand, and sodium oxalate), and sludge materials from Tank 18F. In addition, the Savannah River High Level Waste Division (HLWD) has transferred excess $\mathrm{Pu}$ and $\mathrm{Am} / \mathrm{Cm}$ materials to Tank $51 \mathrm{H}$ to be processed through the DWPF. Current blending strategies also include additional $\mathrm{Pu}$ and a $\mathrm{Np}$ stream from the canyons as materials being vitrified in SB3 in the DWPF.

The transfers from Tank 18F to Tank 7F to be processed at DWPF as part of SB3 have been completed. The sludge materials in Tank 18F contain part of a mound of zeolitic material transferred there from Tank 19F. This mound was physically broken up and transfers were made from Tank 19F to Tank 18F to Tank 7F for vitrification into SB3.

As early as 1979 (prior to the implementation of the Product Composition Control System in DWPF), it was recognized ${ }^{2}$ that the concentration of zeolite in the sludge feed to the DWPF must be limited in order to avoid glass processing problems: high viscosity due to the $\mathrm{Al}_{2} \mathrm{O}_{3}$ content of the zeolite could impact melt rate and pouring. A limit of 20 wt $\%$ zeolite in a given glass melt was proposed which converts to $\leq 0.28 \mathrm{lb}$ of zeolite per gallon of sludge. Prior to processing SB3 in the DWPF, SRTC was requested to perform an assessment of the potential impacts of the zeolitic material on SB3 processing and glass product quality. This evaluation entailed the following: 
- identification of the mound material as degraded (aged) IE-95 zeolite used in cesium recovery columns (CRCs) to remove cesium from the overheads of the SRS Evaporators in F-Area

- identification of the zeolite aging mechanism and impacts on sludge composition and sludge washing

- zeolite density and moisture content

- zeolite particle size distribution and potential impacts on the DWPF Hydragard $^{\circledR}$ sludge sampling system and sample representativeness for DWPF process control

- comparison of composition impacts on blending scenarios using three baseline frits for which similar calculations were available, e.g. frits 320, 165 and 200

- anion content of the zeolite in the mound to determine what anions the converted zeolite contains and any impacts on DWPF processing or glass quality

The nominal sludge compositions and same three existing frits were used as the basis for the composition assessments in this study as used in the earlier projections for SB3 made by Peeler, Bibler, and Edwards. ${ }^{3}$ The impact of zeolite on SB3 was not considered during the earlier projections because the amount of zeolite that could be potentially transferred into SB3 was not available in the Waste Characterization System (WCS). A comparison of the impacts of zeolite with the earlier study, therefore, allows a consistent comparison to be made regarding the potential impact of zeolite on glass processing and waste loading. In both studies it was assumed that the individual sludge scenarios are essentially "compositional centroids" representing an average blend. The blending calculations assume that individual streams will be evenly distributed or uniformly blended resulting in a "constant" feed to the melter (once frit additions are made). Calculations were based on weighed mass averages.

This report documents SRTC's assessment of the potential impacts of the zeolite material in Tank 19F on processing SB3.

\subsection{BACKGROUND}

\subsection{Tank 19F}

Tank 19F is a 1.3 million gallon capacity Type IV waste tank; a flat-bottomed cylindrical carbon steel tank about 85 feet in diameter with a domed roof. The walls are roughly 35 feet high with the center height about 45 feet. There are no cooling coils or supports inside the tank. The Westinghouse Savannah River Company (WSRC) is scheduled to close Tank 19F. ${ }^{4}$

Tank 19F was commissioned in 1961 and initially received a small amount of low heat waste from Tank 17F. It then served as an evaporator concentrate (saltcake) receiver from February 1962 to September 1976. Tank 19F also received the spent ion exchange media from a cesium removal column (CRCs) that once operated in the northeast riser of 
the tank to remove cesium from the evaporator overheads. ${ }^{5}$ When the CRC ion exchange material needed to be replaced, the spent material was dropped into Tank 19F. A similar CRC also processed liquid waste from the receiving basin for off-site fuel (RBOF) and the resin regeneration facility (RRF) in $\mathrm{H}$-Area. This spent ion exchange media was dropped into Tank $24 \mathrm{H}$.

The filter material used in the F-Area CRCs prior to 1963 was a precipitated gel-type sodium aluminosilicate cation exchanger ${ }^{6}$ known as Decalso (Ionac C-103). After 1963, Linde AW-500 zeolite (subsequently renamed Ion-Exchange-95 and known as IE-95) was used in both F and H-Area CRCs. Six batches, 1950 lbs., of Decalso were discharged to Tank 19F while 54,600 lbs. of Linde AW500 were discharged to Tank 19F as of August $1979^{5}$ (about a year before deinventory of Tank 19F began). Similarly, 197,275 lbs. of Linde AW500 were discharged to Tank 24H.

\subsection{Tank 19F Transfers to Tank 18F}

From July 1980 to July 1981, greater than one million gallons of radioactive waste salt were deinventoried from Tank 19F using mechanical agitation consisting of two 1200gpm long-shafted jet mixer pumps located in the east and west risers. This method involved adding inhibited water to the tank and stirring the contents with the long-shafted pumps. The resulting salt solution was sent to Tank 18F. Four batch transfers were conducted to remove the salt inventory in Tank 19F. About $98 \%$ of the salt and $86 \%$ of the radionuclides were removed. Greater than 2,300,000 gallons of water were added to process the four batches. ${ }^{7}$

At the completion of the salt removal campaign, approximately 33,000 gallons of solids remained in an hourglass-shaped formation (running north to south) on the tank bottom. The solids heel composition was estimated to be 13,000 gallons (40\%) of spent zeolite resin, 7,000 gallons (20\%) of metal oxides/hydroxides (standard sludge), and 13,000 gallons (40\%) of solid salts. ${ }^{7,8}$ Most likely, very little zeolite was transferred to Tank $18 \mathrm{~F}$ during the salt removal campaign. Since the primary purpose of the campaign was to remove salt, agitating the entire tank was not a priority.

A second, more aggressive, waste removal campaign ensued from September 2000 to June 2001. Multiple Flygt mixer orientations and schemes based on testing and experience in Tank 19F were used to provide the maximum removal of the Tank 19F solids, including zeolite. This reduced the solid heel volume from 33,000 gallons to approximately 15,000 gallons. ${ }^{9,10}$ This means that $\sim 18,000$ gallons of the heel could have been transferred forward to Tank $18 \mathrm{~F}$ and ultimately to SB3. .

Three grab samples of the residual mound material in Tank 19F have been analyzed (1986, 1996, and 2000). The materials composing the grab samples were gathered from the top several inches of the heel. The grab sample taken in 2000 (FTF-024) was a crusty material blocking installation of a transfer pump and thought to be non-representative of the radionuclides in the tank. The analytical results of the grab samples suggest a primary composition of sodium aluminosilicate minerals and sludge. ., 11, 12 Two additional grab samples (FTF-075 and FTF-077) and a core sample (FTF-118) were taken from Tank 
19F in September 2001 and analyzed. ${ }^{13}$ A summary and comparison of the analyses from these studies is given in Table I.

The Tank 19F mound material was found to be composed primarily of sludge (traces of $\mathrm{Al}(\mathrm{OH})_{3}$ were identified in sample FTF-024) and a nitrated aluminosilicate mineral, $\mathrm{Na}_{8} \mathrm{Al}_{6} \mathrm{Si}_{6} \mathrm{O}_{24}\left(\mathrm{NO}_{3}\right)_{2} \bullet 4 \mathrm{H}_{2} \mathrm{O}$. The aluminosilicate mineral phase was assumed to be an aged or converted analogue of the original zeolite ion exchange media. ${ }^{14}$ Based on the wt\% silica analyzed in the 1996 Tank 19F solids sample (Table I) and the composition of the aged ion exchange media, it was estimated that the Tank 19F solids were $\sim 50 \mathrm{wt} \%$ zeolite. Based on the 1986 sample analysis the wt\% zeolite in the solids were estimated as $57 \mathrm{wt} \%$ zeolite while the 2000 sample (FTF-024) suggests that the zeolite in the solids can be as high as $\sim 80 \%{ }^{12}$ Using the average of the Si analyses shown in Table I, d'Entremont and Thomas projected that $61.8 \%$ of the Tank 19F solids were zeolite (seeTable III). The d'Entremont and Thomas average excluded the results from the 2000 FTF-024 sample claiming that this sample was non-representative of most of the Tank 19F solids since the tank had not been slurried at the time the 2000 sample had been taken, and pictures of the mound from which the sample was obtained indicated it was composed of slabs of hard, crusty material that did not resemble the other solids in the tank. However, based on the low water content of this sample as measured in this study (Section 5.3) for FTF-024 in Table I, FTF-024 appears to be a more aged or more dehydrated sample of zeolite than the FTF-075, FTF-077, and FTF-118 samples. The d'Entremont and Thomas ${ }^{4}$ average composition also does not include the data from the 1986 analysis because the chemical analyses performed were incomplete, the sample had been washed, and the soluble and insoluble portions of the sample had been analyzed separately. Probably the most representative value of the mound contents is the analysis of the 2001 core sample which suggests that $67 \%$ of the solids are spent zeolite.

d'Entremont and Thomas ${ }^{4}$ also estimated the amount of Purex Low Heat Waste in the Tank 19F solids based on the fact that the Purex waste contains about $24 \mathrm{wt} \%$ iron $^{11}$ and is the only source of iron in the Tank 19F solids. Thus, it can be assumed that most of the iron in the solids came from the Purex Low Heat Waste. The remainder is assumed to be coating waste which contains no signature element. Coating waste was produced when the aluminum coating on the target assemblies was dissolved away using sodium hydroxide; the waste is largely aluminum hydroxide. Aluminum is also a component of the Purex Low Heat Waste and zeolite.

Assuming the zeolite can be represented by nitrated sodalite with a chemical formula of $\mathrm{Na}_{8}\left(\mathrm{Al}_{6} \mathrm{Si}_{6} \mathrm{O}_{24}\right)\left(\mathrm{NO}_{3}\right)_{2} * 4 \mathrm{H}_{2} \mathrm{O}$, the compositions of the major chemical constituents remaining in Tank 19F, Purex Low Heat Waste, and hydrated sodalite are given in Table II from the d'Entremont and Thomas reference. ${ }^{4}$ The contribution of each of the species to the 15,000 gallons of Tank 19F solids remaining in Tank 19F are given in Table III from the d'Entremont and Thomas reference. ${ }^{4}$ If the 18,000 gallons transferred out of the 33,000 gallons remaining in Tank $19 \mathrm{~F}$ after the salt removal campaign was $40 \%$ spent zeolite resin, $40 \%$ salt solids, and $20 \%$ sludge as indicated in references 7 and 8 , then 13,200 gallons $\left(105,864 \mathrm{lbs}\right.$. or $48,120 \mathrm{kgs}$. at $\left.\rho_{\text {meas }}=8.02 \mathrm{lbs} / \mathrm{gal}^{15}\right)$ of zeolite mound could have been transferred to Tank 18F from Tank 19F. However, d'Entremont and Thomas ${ }^{4}$ indicate that 9,267 gallons of the 15,000 gallons remaining in Tank 19F is 
zeolite (Table III) which indicates that the sludge and salt solids got transferred to Tank $18 \mathrm{~F}$ preferentially and only 3933 gallons $\left(31,542 \mathrm{lbs}\right.$. or $14,338 \mathrm{kgs}$. at $\rho_{\text {meas }}=8.02$ lbs/gal) of zeolite solids got transferred from Tank 19F to Tank 18F.

Table I Chemical Analyses in Element Wt\% for Tank $19 \mathrm{~F}$ Solids dried at $105-115^{\circ} \mathrm{C}$

\begin{tabular}{|c|c|c|c|c|c|c|c|}
\hline Element & $\begin{array}{c}\text { No.1 } \\
\text { Bulk } \\
\text { Solids } \\
\text { Aug-867 }\end{array}$ & $\begin{array}{c}\text { No. } 2 \\
\text { Bulk } \\
\text { Solids } \\
\text { Aug-9611 }\end{array}$ & $\begin{array}{c}\text { No. } 3 \\
\text { Crusty } \\
\text { Solids } \\
\text { Dec-0012 } \\
\text { (FTF-024) }\end{array}$ & $\begin{array}{c}\text { No.4 } \\
\text { Bulk } \\
\text { Solids } \\
\text { Sept-01 } \\
\text { (FTF-075) }\end{array}$ & $\begin{array}{c}\text { No. } 5 \\
\text { Bulk } \\
\text { Solids } \\
\text { Sept-01 } \\
\text { (FTF-077) }\end{array}$ & $\begin{array}{c}\text { No. } 6 \\
\text { Cored } \\
\text { Solids } \\
\text { Dec-01 } \\
\text { (FTF-118) }\end{array}$ & $\begin{array}{c}\text { Average }^{4} \\
\text { Excluding } \\
\text { Cases } 1 \text { \&3 }\end{array}$ \\
\hline & (wt. \%) & (wt. \%) & (wt. \%) & (wt. \%) & (wt. \%) & (wt. \%) & (wt. \%) \\
\hline Silver & & 0.02 & & 0.006 & 0.006 & 0.02 & 0.01 \\
\hline Aluminum & 22.9 & 14.8 & 15.3 & 14.4 & 13.9 & 12.4 & 13.9 \\
\hline Boron & & 0.04 & 0.003 & 0.01 & $\leq 0.004$ & $\leq 0.006$ & 0.015 \\
\hline Barium & & 0.095 & 0.029 & 0.07 & 0.096 & 0.10 & 0.09 \\
\hline Calcium & & 0.80 & 1.48 & 0.79 & 0.84 & 1.10 & 0.88 \\
\hline Cadmium & & 0.007 & 0.006 & 0.011 & 0.01 & 0.008 & 0.009 \\
\hline Cerium & & 0.21 & & $<0.36$ & $<0.39$ & $<0.32$ & 0.31 \\
\hline Cobalt & & 0.003 & 0.01 & 0.006 & 0.007 & 0.011 & 0.008 \\
\hline Chromium & & 0.03 & 0.026 & 0.039 & 0.032 & 0.035 & 0.034 \\
\hline Copper & & 0.009 & 0.003 & $<0.004$ & $<0.004$ & 0.005 & 0.0057 \\
\hline Iron & 1.66 & 2.85 & 1.46 & 1.64 & 1.90 & 2.20 & 2.15 \\
\hline Lanthanum & & 0.03 & 0.03 & $<0.01$ & $<0.01$ & 0.024 & 0.018 \\
\hline Lithium & & 0.008 & 0.005 & 0.004 & 0.004 & $\leq 0.003$ & 0.005 \\
\hline Magnesium & & 0.024 & 0.41 & 0.24 & 0.26 & 0.26 & 0.25 \\
\hline Manganese & 0.32 & 0.14 & 0.06 & 0.14 & 0.145 & 0.123 & 0.137 \\
\hline Molybdenum & & 0.003 & 0.007 & $\leq 0.01$ & $\leq 0.009$ & $\leq 0.009$ & 0.008 \\
\hline Sodium & & 15.7 & & 17.4 & 17.0 & 16.1 & 16.5 \\
\hline Nickel & & 0.01 & 0.017 & 0.016 & 0.015 & 0.012 & 0.013 \\
\hline Phosphorus & & 0.05 & 0.035 & $<0.042$ & $\leq 0.044$ & 0.037 & 0.043 \\
\hline Lead & & 0.05 & 0.27 & $\leq 0.05$ & $\leq 0.05$ & 0.05 & 0.05 \\
\hline Silicon & 8.82 & 7.74 & 12.3 & 9.91 & 10.00 & 10.4 & 9.51 \\
\hline Tin & & 0.01 & 0.27 & $<0.025$ & $\leq 0.02$ & $\leq 0.024$ & 0.02 \\
\hline Strontium & & 0.02 & 0.03 & 0.02 & 0.02 & 0.02 & 0.02 \\
\hline Titanium & & 0.05 & 0.095 & 0.047 & 0.06 & 0.064 & 0.055 \\
\hline Vanadium & & 0.007 & 0.006 & 0.007 & 0.007 & 0.013 & 0.008 \\
\hline Zinc & & 0.009 & 0.006 & $\leq 0.006$ & $\leq 0.005$ & 0.008 & 0.007 \\
\hline Zirconium & & 0.008 & & 0.013 & 0.019 & 0.017 & 0.014 \\
\hline Mercury & 0.067 & 0.004 & & 0.005 & 0.004 & $<0.01$ & 0.006 \\
\hline Potassium & & & & 0.014 & 0.011 & $<0.01$ & 0.011 \\
\hline $\begin{array}{l}\text { Water by } \\
\text { weight loss } \\
\text { on drying }\end{array}$ & 19.0 & 25.0 & $4.3^{\star}$ & 34.7 & 32.8 & 23.3 & $28.9^{\star \star}$ \\
\hline
\end{tabular}

* calculated from Equation 3 in this study

** calculated from data in this table, value not given in reference 4 
Table II Major Waste Species in Tank $19 \mathrm{~F}^{4}$

\begin{tabular}{|c|c|c|c|}
\hline Element & $\begin{array}{c}\text { Tank 19F } \\
\text { Samples }\end{array}$ & $\begin{array}{c}\text { Purex } \\
\text { LHW }\end{array}$ & $\begin{array}{c}\text { Hydrated } \\
\text { sodalite }\end{array}$ \\
\hline & (wt\%) & (wt\%) & (wt\%) \\
\hline & & & \\
\hline $\mathrm{Al}$ & 13.9 & 4.7 & 14.8 \\
\hline $\mathrm{Fe}$ & 2.1 & 24.3 & 0.0 \\
\hline $\mathrm{Na}$ & 16.5 & 3.8 & 16.8 \\
\hline $\mathrm{Si}$ & 9.5 & 0.9 & 15.4 \\
\hline & & & \\
\hline & 42.1 & 33.6 & 47.0 \\
\hline
\end{tabular}

Table III Constituents Remaining as Solids in Tank $19 F^{4}$

\begin{tabular}{|l|c|c|c|}
\hline Constituent & $\begin{array}{c}\text { Average } \\
\text { Estimated } \\
\text { wt\% }\end{array}$ & $\begin{array}{c}\text { Quantity } \\
\text { Remaining in } \\
\text { Tank 19F (gal) }\end{array}$ & Based on: \\
\hline Zeolite (hydrated sodalite) & 61.8 & 9,267 & $\mathrm{Si}$ \\
\hline Purex Low Heat Waste & 8.8 & 1,324 & $\mathrm{Fe}$ \\
\hline Other (primarily coating waste) & 29.4 & 4,410 & Balance \\
\hline Totals & 100.00 & 15,000 & \\
\hline
\end{tabular}




\subsection{Zeolite Mineralogy}

As early as 1979, the IE-95 (AW-500) zeolite used in the SRS CRC's was known to be primarily the mineral chabazite (a zeolite) mixed with a clay binder (20-25 wt\%); the species had been co-fired at $650^{\circ} \mathrm{C}$ resulting in 20-50 mesh resin particles. ${ }^{2} \mathrm{The}$ IE-95 was analyzed in $1988^{16}$ and found to be a mixture of $\sim 30 \mathrm{~mol} \%$ erionite, $50 \mathrm{~mol} \%$ chabazite, and $\sim 20 \mathrm{~mol} \%$ clay (see Figure 1), where each component had the following nominal composition:

Erionite (PDF \#22-854) $)^{f:} \quad\left(\mathrm{K}_{2.4} \mathrm{Na}_{3.9} \mathrm{Ca}_{0.3} \mathrm{Mg}_{0.8}\right)\left[\left(\mathrm{Al}_{7.1} \mathrm{Fe}_{0.5}\right) \mathrm{Si}_{28.1} \mathrm{O}_{72}\right] \cdot 23 \mathrm{H}_{2} \mathrm{O}$

Chabazite (PDF \#34-137): $\quad\left(\mathrm{Na}_{1.0} \mathrm{Ca}_{1.5}\right)\left[\mathrm{Al}_{4} \mathrm{Si}_{8} \mathrm{O}_{24}\right] \cdot 12 \mathrm{H}_{2} \mathrm{O}$

Clay: $\quad \mathrm{Mg}_{0.85} \mathrm{Al}_{0.50} \mathrm{Fe}_{1.7} \mathrm{Si}_{14} \mathrm{O}_{32} \cdot 4 \mathrm{H}_{2} \mathrm{O}$

In 1980, Fowler and Wallace examined the zeolite in Tank 24H and determined by $\mathrm{x}$-ray diffraction (XRD) analysis that the IE-95 chabazite mineral phase had converted to natrodavyne $\left(\mathrm{Na}_{6}\left[\mathrm{Al}_{6} \mathrm{Si}_{6} \mathrm{O}_{24}\right]\left(\mathrm{Na}_{2} \mathrm{CO}_{3}\right)\right)$ and that some of the 20-50 mesh particles had been broken down to finely divided solids. Natrodavyne is in the hexagonal structured cancrinite family of minerals. In 1996, Hay ${ }^{14}$ examined the zeolite in Tank $19 \mathrm{~F}$ and determined by XRD analysis that the IE-95 had converted to nitrated sodalite/cancrinite $\left(\mathrm{Na}_{8}\left[\mathrm{Al}_{6} \mathrm{Si}_{6} \mathrm{O}_{24}\right]\left(\mathrm{NO}_{3}\right)_{2} * 4 \mathrm{H}_{2} \mathrm{O}\right)$. Lastly, in 2001 Swingle $^{12}$ determined that the IE-95 had converted to a mixture of hexagonal hydroxy-cancrinite $\left(\mathrm{Na}_{6}\left[\mathrm{Al}_{6} \mathrm{Si}_{6} \mathrm{O}_{24}\right](2 \mathrm{NaOH}) \cdot 4 \mathrm{H}_{2} \mathrm{O}\right)$ and cubic nitrated sodalite $\left(\mathrm{Na}_{6}\left[\mathrm{Al}_{6} \mathrm{Si}_{6} \mathrm{O}_{24}\right]\left(2 \mathrm{NaNO}_{3}\right)\right)$ as shown in Figure 2.

While the use of the varying mineral names is confusing, it is important to note that sodalite and cancrinite family of minerals are structurally related and that natrodavyne is a mineral in the cancrinite family. All sodalite and cancrinite minerals share a common cage like aluminosilicate structure (Figure 3) indicated by the square brackets in each formula, e.g. $\left[\mathrm{Al}_{6} \mathrm{Si}_{6} \mathrm{O}_{24}\right]$ indicating a cage made up of silica and alumina tetrahedra. The sodalites have a cubic structure while the cancrinites have a hexagonal structure. Crystallographically, cubic and hexagonal (including rhombohedral) structures share common densley packed planes as shown in Figure 4 which makes the XRD identification of the unique species difficult because the Bragg reflections (peaks) in the spectra often overlap.

$f$ PDF $=$ Powder Diffraction File \# 


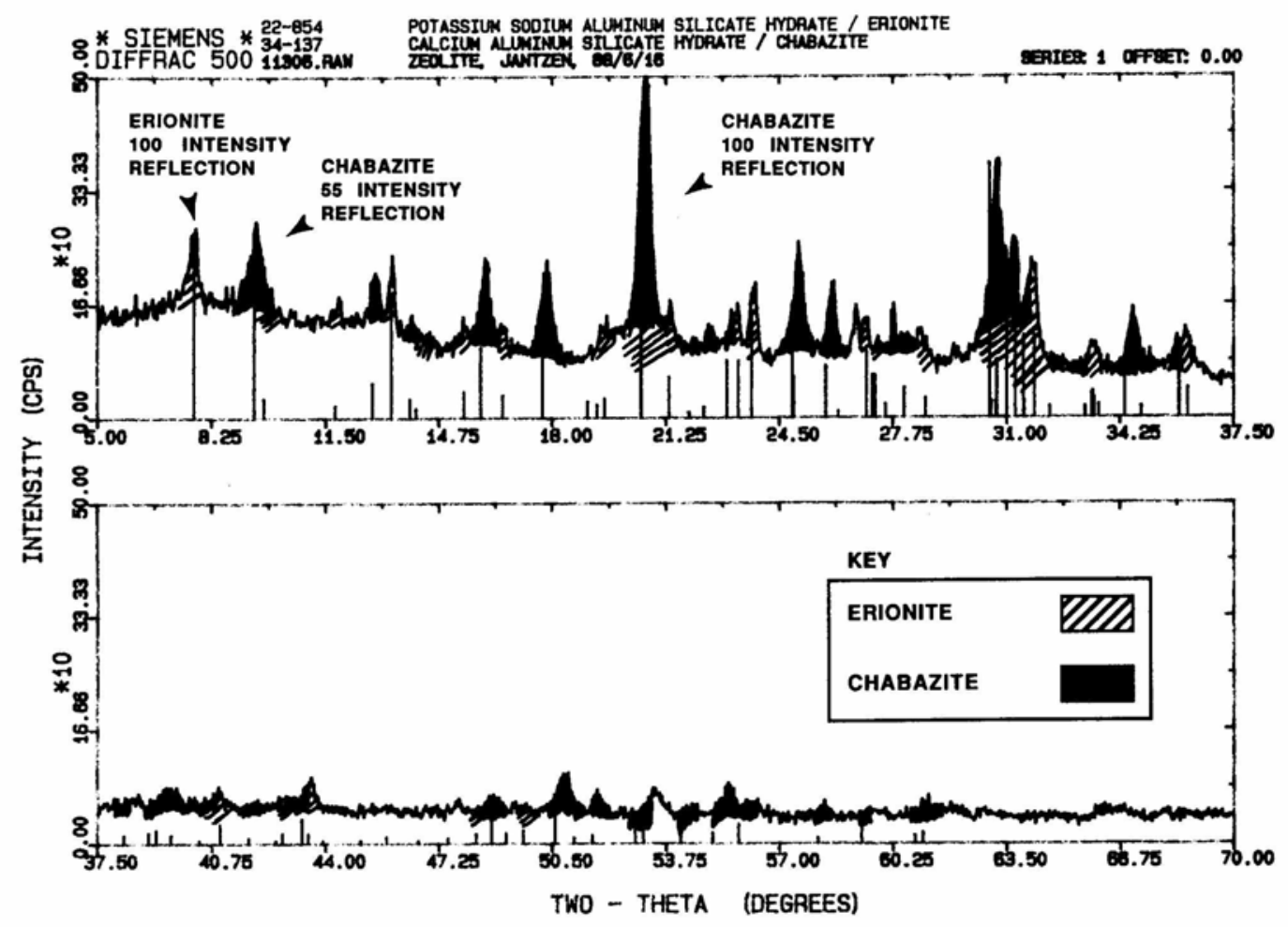

Figure 1 X-ray Diffraction analysis of IE-95 performed in $1988 .^{16}$

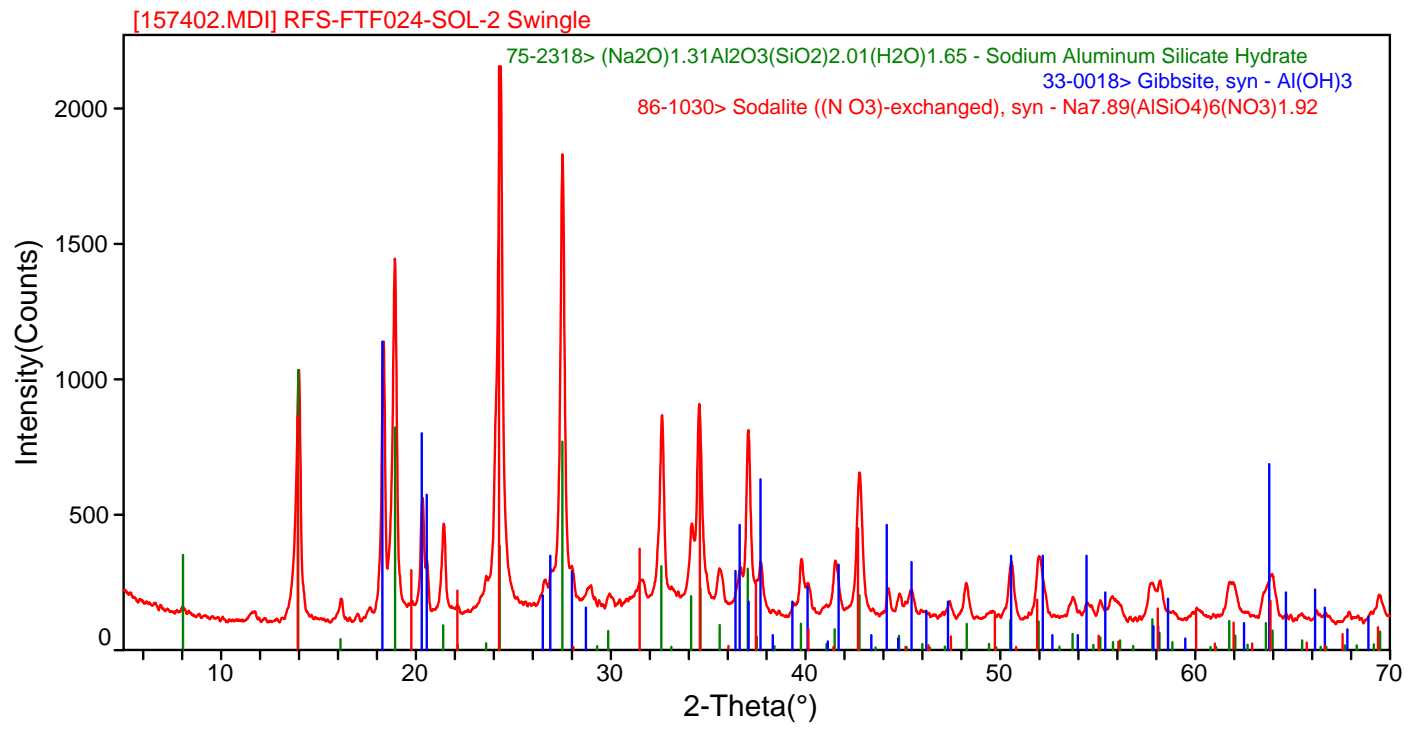

Figure 2. Analysis of converted IE-95 from Tank 19F. ${ }^{12}$ 


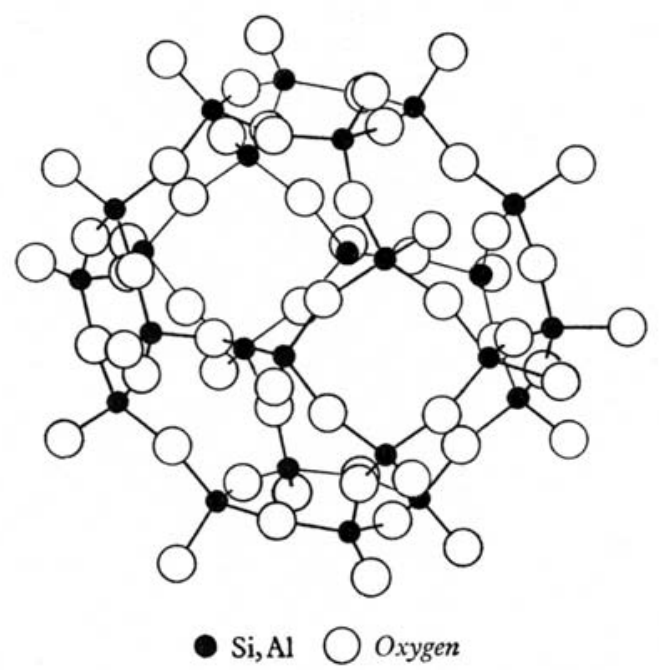

Figure 3. Part of the aluminosilicate framework in the structure of sodalite. ${ }^{17}$

The nomenclature within the cubic sodalite and hexagonal cancrinite mineral families is based on the sodium salt that occupies the cavities in each framework. ${ }^{17}$ Thus the formula for sodalite found in nature can be written as $\mathrm{Na}_{6}\left[\mathrm{Al}_{6} \mathrm{Si}_{6} \mathrm{O}_{24}\right] \bullet(2 \mathrm{NaCl})$ to indicate that two $\mathrm{NaCl}$ are in the cavities of the cage structure while the remaining $\mathrm{Na}: \mathrm{Si}$ :Al have a 1:1:1 stoichiometry. ${ }^{17}$ Substitution of $\mathrm{Na}_{2} \mathrm{SO}_{4}, \mathrm{Na}_{2} \mathrm{CO}_{3}, \mathrm{NaNO}_{3}$, and/or $\mathrm{NaOH}$ into the cage like structure gives the mineral nomenclature in Table IV. Thus the analyses of Fowler and Wallace, ${ }^{5}$ Hay, ${ }^{14}$ and Swingle ${ }^{12}$ are all in basic agreement, e.g.chabazite has transformed into a sodalite/cancrinite cage-like structure with substitution of a combination of $\mathrm{Na}_{2} \mathrm{CO}_{3}$ and $\mathrm{NaNO}_{3}$ in the cage.

\subsection{EXPERIMENTAL}

The composition of Decalso was analyzed by $\mathrm{LiBO}_{2}$ fusion with an $\mathrm{HNO}_{3} / \mathrm{HCl}$ uptake (Procedure L28 1.8) followed by Inductively Coupled Plasma Emission Spectroscopy (ICP-ES). The ICP-ES was performed by the SRTC Mobile Laboratory (ML) for the major cation constituents, $\mathrm{Na}, \mathrm{Ca}, \mathrm{Al}$, and $\mathrm{Si}$. The sample was run in duplicate using Waste Compliance Plan (WCP) glass Batch 1 as a standard. The phase composition of the Decalso was analyzed by SRTC Analytic Development Section (ADS) by XRD.

The water content of the Decalso was measured at $105^{\circ} \mathrm{C}$ and at the elevated temperatures of $300^{\circ} \mathrm{C}, 600^{\circ} \mathrm{C}$, and $900^{\circ} \mathrm{C}$. The water content of sample FTF- 024 was measured at $300^{\circ} \mathrm{C}, 600^{\circ} \mathrm{C}$, and $900^{\circ} \mathrm{C}$ in the SRTC Shielded Cell Facility (SCF). The Tank 19F sample was not washed before analysis. 
Table IV. Structurally Related Sodalite and Cancrinite Mineral Phases

\begin{tabular}{|c|c|c|c|c|c|}
\hline $\begin{array}{l}\text { Substitution In } \\
\text { Cage Structure }\end{array}$ & Chemical Formula & $\begin{array}{c}\text { Common or } \\
\text { Mineral Name }\end{array}$ & $\begin{array}{l}\text { Density } \\
(\mathrm{g} / \mathrm{cm} 3)\end{array}$ & $\begin{array}{c}\text { Crystal } \\
\text { Type }\end{array}$ & Ref. \\
\hline \multicolumn{6}{|l|}{ Sodalite Group } \\
\hline $2 \mathrm{NaCl}$ & $\mathrm{Na}_{6}\left[\mathrm{Al}_{6} \mathrm{Si}_{6} \mathrm{O}_{24}\right](2 \mathrm{NaCl})$ & Sodalite & $2.31^{*}$ & Cubic $^{*}$ & 17 \\
\hline $2 \mathrm{NaOH}$ & $\mathrm{Na}_{6}\left[\mathrm{Al}_{6} \mathrm{Si}_{6} \mathrm{O}_{24}\right](2 \mathrm{NaOH}) \bullet 1.5 \mathrm{H}_{2} \mathrm{O}$ & $\begin{array}{l}\text { Basic Sodalite or } \\
\text { Hydroxysodalite }\end{array}$ & $2.215^{* *}$ & Cubic $^{* *}$ & 18 \\
\hline $2 \mathrm{NaNO}_{3}$ & $\mathrm{Na}_{6}\left[\mathrm{Al}_{6} \mathrm{Si}_{6} \mathrm{O}_{24}\right]\left(2 \mathrm{NaNO}_{3}\right)$ & Nitrated Sodalite & 2.342 & Cubic & $\begin{array}{l}\text { PDF\#50- } \\
0248\end{array}$ \\
\hline $\mathrm{Na}_{2} \mathrm{SO}_{4}$ & $\mathrm{Na}_{6}\left[\mathrm{Al}_{6} \mathrm{Si}_{6} \mathrm{O}_{24}\right]\left(\mathrm{Na}_{2} \mathrm{SO}_{4}\right)$ & Nosean & 2.21 & Cubic & $\begin{array}{l}\text { PDF \#17- } \\
538\end{array}$ \\
\hline $\mathrm{xNaOH}+\mathrm{y} \mathrm{H}_{2} \mathrm{O}$ & $\mathrm{Na}_{6}\left[\mathrm{Al}_{6} \mathrm{Si}_{6} \mathrm{O}_{24}\right](\mathrm{xNaOH}) \bullet y \mathrm{H}_{2} \mathrm{O}$ & Basic Nosean & & & 18 \\
\hline $1-2(\mathrm{Ca}, \mathrm{Na}) \mathrm{SO}_{4}$ & $(\mathrm{Na})_{6}\left[\mathrm{Al}_{6} \mathrm{Si}_{6} \mathrm{O}_{24}\right]\left((\mathrm{Ca}, \mathrm{Na}) \mathrm{SO}_{4}\right)_{1-2}$ & Hauyne & 2.4 & Cubic & $\begin{array}{c}\text { PDF \#20- } \\
1087 \\
\end{array}$ \\
\hline $\mathrm{x}(\mathrm{Ca}, \mathrm{Na})\left(\mathrm{S}, \mathrm{SO}_{4}, \mathrm{Cl}\right)$ & $(\mathrm{Ca}, \mathrm{Na})_{6}\left[\mathrm{Al}_{6} \mathrm{Si}_{6} \mathrm{O}_{24}\right]\left((\mathrm{Ca}, \mathrm{Na}) \mathrm{S}, \mathrm{SO}_{4}, \mathrm{Cl}\right)_{\mathrm{x}}$ & Lazurite & 2.43 & Cubic & $\begin{array}{c}\text { PDF } \\
\# 17-749\end{array}$ \\
\hline \multicolumn{6}{|c|}{ Cancrinite Group } \\
\hline $2 \mathrm{NaNO}_{3}$ & $\mathrm{Na}_{6}\left[\mathrm{Al}_{6} \mathrm{Si}_{6} \mathrm{O}_{24}\right]\left(2 \mathrm{NaNO}_{3}\right) \cdot 4 \mathrm{H}_{2} \mathrm{O}$ & Nitrated Cancrinite & 2.51 & Hexagonal & $\begin{array}{l}\text { PDF \#38- } \\
513\end{array}$ \\
\hline$(\mathrm{Na}, \mathrm{Ca}, \mathrm{K})_{2} \mathrm{CO}_{3}$ & $\begin{array}{c}(\mathrm{Na}, \mathrm{Ca}, \mathrm{K})_{6}\left[\mathrm{Al}_{6} \mathrm{Si}_{6} \mathrm{O}_{24}\right]\left((\mathrm{Na}, \mathrm{Ca}, \mathrm{K})_{2} \mathrm{CO}_{3}\right)_{1} \\
.6 \\
\bullet 2.1 \mathrm{H}_{2} \mathrm{O}\end{array}$ & Cancrinite & 2.60 & Hexagonal & $\begin{array}{l}\text { PDF \#25- } \\
776\end{array}$ \\
\hline $2(\mathrm{Na}, \mathrm{K}) \mathrm{Cl}$ & $(\mathrm{Na}, \mathrm{Ca}, \mathrm{K})_{6}\left[\mathrm{Al}_{6} \mathrm{Si}_{6} \mathrm{O}_{24}\right](2(\mathrm{Na}, \mathrm{K}) \mathrm{Cl})_{2-3}$ & Microsommite & 2.34 & Hexagonal & $\begin{array}{c}\text { PDF } \\
\# 20-743\end{array}$ \\
\hline $\begin{array}{c}(\mathrm{Na}, \mathrm{K}) \mathrm{Cl} \text { and } \\
(\mathrm{Na}, \mathrm{K}) \mathrm{SO}_{4}\end{array}$ & $(\mathrm{Na}, \mathrm{Ca}, \mathrm{K})_{6}\left[\mathrm{Al}_{6} \mathrm{Si}_{6} \mathrm{O}_{24}\right]\left((\mathrm{Na}, \mathrm{K})_{2} \mathrm{SO}_{4}, \mathrm{Cl}\right)_{3}$ & Davyne & 2.46 & Hexagonal & $\begin{array}{c}\text { PDF } \\
\# 20-379\end{array}$ \\
\hline $\mathrm{Na}_{2} \mathrm{CO}_{3}$ & $\mathrm{Na}_{6}\left[\mathrm{Al}_{6} \mathrm{Si}_{6} \mathrm{O}_{24}\right]\left(\mathrm{Na}_{2} \mathrm{CO}_{3}\right)$ & Natrodavyne & $\begin{array}{l}\text { Not } \\
\text { given }\end{array}$ & Hexagonal & $\begin{array}{c}\text { PDF } \\
\# 15-794\end{array}$ \\
\hline
\end{tabular}

$\begin{array}{lll}* & \text { PDF \# 20-495 } & \text { \# PDF \#11-0590 and \#38-241 } \\ * * & \text { PDF \#11-401 }\end{array}$




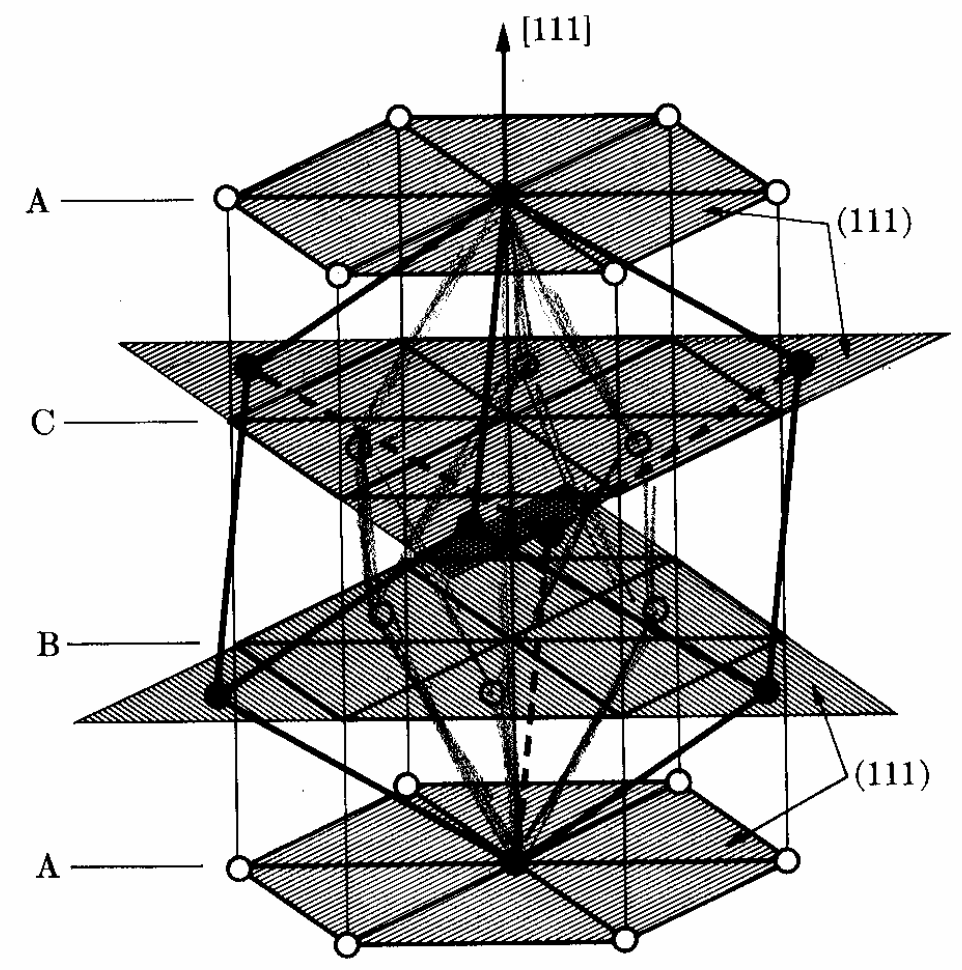

FACE-CENTERED CUBIC

Figure 4. Relationship between the atomic lattices of hexagonal, rhombohedral, and cubic crystal lattices of the sodalite/cancrinite minerals (from Reference 19).

The anion content of the Tank 19F grab sample was also measured by SRTC-ADS by Ion Chromotography (IC) for formate, fluoride, chloride, nitrate, sulfate, oxalate, phosphate, and nitrite.

The bulk density of unreacted IE-95 was measured in this study in a graduated cylinder and 10cc of the zeolite then weighed. The mineral density, exclusive of void volume, of the IE-95 was measured in duplicate by air pycnometry. In a separate study, ${ }^{15}$ the density of moist mound unreacted IE-95 was remeasured and compared to the density of the Tank 19F solids (FTF-075 (grab sample), FTF-077 (grab sample), and FTF-118 (core sample), that were measured using calibrated graduated centrifuge tubes.

The particle size of the Decalso and unreacted IE-95 was measured by SRTC ADS with a Microtrac-SRA 150 particle size analyzer. If the particle size exceeded the upper limit of the Microtrac which was $704 \mu \mathrm{m}$, then the particle size was measured using a set of nested sieves ranging from 0.25 ” to 0.0278 ” $(707 \mu \mathrm{m})$ so that the sieve measurement and the particle size analyzer ranges overlapped. The weight percent of the IE-95 was converted to volume \% by using the mineral phase density measured by air pycnometry. 
The particle size of the Tank 19F crusty sample was measured with the same MicrotracSRA 150 particle size analyzer in a radioactive hood in SRTC. The radioactive particle size analysis was performed three times and the results were averaged.

Conversion of the IE-95 in the presence of high caustic was determined by placing 5 grams of unreacted IE-95 into $30 \mathrm{~mL}$ of $5 \mathrm{M}$ and $10 \mathrm{M} \mathrm{NaOH}$ at $90^{\circ} \mathrm{C}$ for varying amounts of time, e.g. 2 day, 5 day, 7 day, 14 day, 21 day, and 28 day. In addition, 5 grams of Decalso was subjected to $10 \mathrm{M} \mathrm{NaOH}$ for 2 days at $90^{\circ} \mathrm{C}$ while 5 grams of IE-95 was subjected to $10 \mathrm{M} \mathrm{CsOH}$ at $90^{\circ} \mathrm{C}$ for 7 days. Half of the samples were washed with deionized water and half were left unwashed. The washed and unwashed samples were dried at $90^{\circ} \mathrm{C}$ overnight. Each of the reaction products, washed and unwashed, was analyzed by XRD.

\subsection{QUALITY ASSURANCE}

All analyses were conducted by ADS and the SRTC ML according to their routine operating and quality assurance procedures. All sample preparation work was conducted by Shielded Cells Operations personnel, according to written instructions provided by Waste Processing Technology personnel.

\subsection{RESULTS AND DISCUSSION}

\subsection{Tank 19F Solids}

The analyses of the Tank 19F solids are summarized from previous works in Table I. Anion analyses were not reported in Table I because none had previously been measured. The Tank 19F crusty grab sample (FTF-024) was measured by IC for the various anions shown in Table $\mathrm{V}$. The only anion of consequence is nitrate which is present at $8.6 \mathrm{wt} \%$ indicating that the major anion in the converted zeolite is $\mathrm{NO}_{3}{ }^{-}$. This confirms the identification of the nitrated sodalites/cancrinites and indicates that no nitrite is substituting into the cage structure of the converted ion exchange media.

The FTF-024 sample had been dried to a constant weight at $115^{\circ} \mathrm{C}$ before analyses were completed. While this drives off free and adsorbed water it does not drive off the anions or structural $\mathrm{OH}$ or $\mathrm{H}_{2} \mathrm{O}$ molecules. Therefore, a mass balance calculation was performed on the chemical analyses in Table I by assuming that each had approximately the same amount of nitrate as FTF-024 (Table V). This mass balance demonstrates (Table VI) that excess $\mathrm{Al}(\mathrm{OH})_{3}$ is present in most samples as evidenced in the $\mathrm{x}$-ray diffraction analysis of FTF-024 (see Figure 2). Since the sample had not been washed of adherent soluble solids and sludge, the mass balance demonstrates that excess $\mathrm{NO}_{3}{ }^{-}$exists over the amount attributed to the sodalite phase in the form of $\mathrm{NaNO}_{3}$. 
The weight loss as a function of temperature was measured for the Tank 19F grab sample at $300^{\circ} \mathrm{C}, 600^{\circ} \mathrm{C}$, and $900^{\circ} \mathrm{C}$ and the values are given in Table VII. Since the sample had not been washed before the weight loss was determined, part of the weight loss could be from adherent sludge and soluble solids.

Lastly, the Tank 19F crusty grab sample was analyzed for particle size using a Microtrac particle size analyzer in the SRTC SCF. The average particle size distributions from three consecutive measurements taken in the SCF on the same sample are given in Table VIII. It should be noted that the maximum particle size is about $700 \mu \mathrm{m}$ which is the maximum value the particle size analyzer in the SCF could measure. The largest volume percent is about $500 \mu \mathrm{m}$.

Table V Anion Analysis of Tank 19F Solids

\begin{tabular}{|c|c|}
\hline Anion & $\begin{array}{c}\text { Tank 19F } \\
\text { Solids } \\
\text { ADS300161741 } \\
\text { FTF=024 }\end{array}$ \\
\hline & (wt\%) \\
\hline $\mathrm{COOH}^{-}$ & $<1.0$ \\
\hline $\mathrm{F}^{-}$ & $<0.2$ \\
\hline $\mathrm{Cl}^{-}$ & $<0.2$ \\
\hline $\mathrm{NO}_{3}{ }^{-}$ & 8.6 \\
\hline $\mathrm{SO}_{4}{ }^{-}$ & $<0.05$ \\
\hline $\mathrm{C}_{2} \mathrm{O}_{4}{ }^{-}$ & $<0.1$ \\
\hline $\mathrm{PO}_{4}$ & $<0.1$ \\
\hline $\mathrm{NO}_{2}{ }^{-}$ & $<1.0$ \\
\hline &
\end{tabular}


Table VI Mass Balance of Chemical Data from Table I and Table V

\begin{tabular}{|l|c|c|c|c|c|c|c|}
\hline Species & $\begin{array}{c}\text { No. 1 } \\
\text { Bulk } \\
\text { Solids } \\
\text { Aug-86 }\end{array}$ & $\begin{array}{c}\text { No. 2 } \\
\text { Bulk } \\
\text { Solids } \\
\text { Aug-96 }\end{array}$ & $\begin{array}{c}\text { No. 3 } \\
\text { Crusty } \\
\text { Solids } \\
\text { Dec-00 }\end{array}$ & $\begin{array}{c}\text { No.4 } \\
\text { Bulk } \\
\text { Solids } \\
\text { Sept-01 } \\
\text { (FTF-024) } \\
\text { (FT5) }\end{array}$ & $\begin{array}{c}\text { No. 5 } \\
\text { Bulk } \\
\text { Solids } \\
\text { Sept-01 } \\
\text { (FTF- } \\
\text { 077) }\end{array}$ & $\begin{array}{c}\text { No. 6 } \\
\text { Cored } \\
\text { Solids } \\
\text { Dec-01 } \\
\text { (FTF-118) }\end{array}$ & $\begin{array}{c}\text { Average } \\
\text { Excluding } \\
\text { No.1 \&2 } \\
\text { From Ref.4 }\end{array}$ \\
\hline & (wt \%) & (wt \%) & (wt \%) & (wt \%) & (wt \%) & (wt \%) & (wt \%) \\
\hline $\mathrm{Fe}(\mathrm{OH})_{3}$ & 3.18 & 5.45 & 2.79 & 3.14 & 3.64 & 4.21 & 4.11 \\
\hline $\mathrm{Al}(\mathrm{OH})_{3}$ & $62.12 *$ & 39.21 & 38.54 & 37.04 & 35.56 & 31.04 & 35.78 \\
\hline $\mathrm{NaNO}$ & 2.89 & 3.98 & 0.00 & 1.79 & 1.70 & 1.30 & 2.20 \\
\hline Sodalite & 57.28 & 50.27 & $79.88 * *$ & 64.36 & 64.94 & 67.54 & 61.76 \\
\hline SUM & 125.47 & 98.90 & 121.21 & 106.33 & 105.84 & 104.08 & 103.85 \\
\hline
\end{tabular}

* likely a bad $\mathrm{Al}$ analysis when compared to remaining analyses

** likely a bad Si analysis when compared to remaining analyses

Table VII Relative weight loss of Tank 19F Sample and Various Ion Exchange Media

\begin{tabular}{|c|c|c|c|}
\hline Temperature $\left({ }^{\circ} \mathbf{C}\right)$ & $\begin{array}{c}\text { Tank 19F } \\
\text { Crusty Grab } \\
\text { Sample }\end{array}$ & $\begin{array}{c}\text { Unreacted } \\
\text { IE-95 }\end{array}$ & Decalso \\
\hline 105 & Not Measured & Not Measured & 8.35 \\
\hline 300 & 6.67 & Not Measured & 15.40 \\
\hline 450 & Not Measured & 12.50 & Not Measured \\
\hline 600 & 10.20 & Not Measured & 17.00 \\
\hline 900 & 13.90 & 15.50 & 18.09 \\
\hline 1150 & Not Measured & 17.66 & Not Measured \\
\hline
\end{tabular}


Table VIII Particle Size Analysis of Tank 19F Sample and Selected Ion Exchange Media

\begin{tabular}{|c|c|c|c|}
\hline Size (Microns) & $\begin{array}{c}\text { Vol\% } \\
\text { Tank 19F Mound } \\
\end{array}$ & $\begin{array}{c}\text { Vol\% } \\
\text { Unreacted IE-95 } \\
\end{array}$ & $\begin{array}{c}\text { Vol\% } \\
\text { Unreacted Decalso } \\
\end{array}$ \\
\hline 1548 & Above range & $0.075 *$ & Above range \\
\hline 1301.5 & Above range & $13.59 *$ & Above range \\
\hline 1094 & Above range & $26.76^{*}$ & Above range \\
\hline 853 & Above range & $43.07 *$ & Above range \\
\hline 704 & 17.13 & 9.45 & 13.77 \\
\hline 497.8 & 26.5 & 3.14 & 46.31 \\
\hline 352 & 10.92 & 0.65 & 27.34 \\
\hline 248.9 & 5.17 & 1.05 & 8.90 \\
\hline 176 & 2.99 & 0.41 & 2.25 \\
\hline 124.45 & 1.39 & 0.23 & 1.17 \\
\hline 88 & 0.45 & 0.16 & 0.26 \\
\hline 62.23 & 1.39 & 0.13 & 0 \\
\hline 44 & 1.77 & 0.13 & 0 \\
\hline 31.11 & 3.95 & 0.14 & 0 \\
\hline 22 & 4.43 & 0.13 & 0 \\
\hline 15.56 & 4.13 & 0.15 & 0 \\
\hline 11 & 4.20 & 0.17 & 0 \\
\hline 7.78 & 3.80 & 0.18 & 0 \\
\hline 5.5 & 4.26 & 0.18 & 0 \\
\hline 3.89 & 1.72 & 0.13 & 0 \\
\hline 2.75 & 1.83 & 0.07 & 0 \\
\hline 1.94 & 1.90 & 0 & 0 \\
\hline 1.38 & 1.53 & 0 & 0 \\
\hline 0.97 & 0.52 & 0 & 0 \\
\hline
\end{tabular}

* determined by sieving and converting from wt\% to vol\% based on a mineral density of $2.28 \mathrm{~g} / \mathrm{cc}$ (see Section 5.2) 


\subsection{Unreacted IE-95 and Decalso Ion Exchange Media}

While the composition of the IE-95 is well documented (see Table IX), no chemical analyses were available for the Decalso ion exchange media reported ${ }^{5}$ to have been discharged to Tank 19F. The chemical analyses performed in this study indicate that the Decalso has the chemical composition shown in Table IX. The Decalso is enriched in $\mathrm{Al}_{2} \mathrm{O}_{3}, \mathrm{SiO}_{2}$ and $\mathrm{Na}_{2} \mathrm{O}$ compared to the IE-95 but contains no $\mathrm{Fe}_{2} \mathrm{O}_{3}, \mathrm{MgO}$, or $\mathrm{K}_{2} \mathrm{O}$. The wt $\%$ water loss at $105^{\circ} \mathrm{C}$ is $8.35 \mathrm{wt} \%$ (see Table VII) which is included in the chemical composition given in Table IX.

Table IX. Composition of IE-95 and Decalso Ion Exchange Media Sent to Tank 19F

\begin{tabular}{|c|c|c|c|}
\hline Oxide & $\begin{array}{c}\text { IE-95 } \\
\text { (Jantzen }\end{array}$ & $\begin{array}{c}\text { Decalso } \\
\text { )eplicate A } \\
\text { ML02-7481 }\end{array}$ & $\begin{array}{c}\text { Decalso } \\
\text { Replicate B } \\
\text { ML02-7481 }\end{array}$ \\
\hline & $\left(\mathrm{wt}^{2}\right)$ & $(\mathrm{wt} \%)$ & $(\mathrm{wt} \%)$ \\
\hline $\mathrm{Al}_{2} \mathrm{O}_{3}$ & 13.7 & 16.93 & 16.98 \\
\hline $\mathrm{Na}_{2} \mathrm{O}$ & 2.7 & 10.50 & 10.46 \\
\hline $\mathrm{Fe}_{2} \mathrm{O}_{3}$ & 3.3 & & \\
\hline $\mathrm{SiO}_{2}$ & 58.3 & 64.17 & 64.16 \\
\hline $\mathrm{CaO}$ & 3.8 & 0.05 & 0.05 \\
\hline $\mathrm{MgO}$ & 1.1 & & \\
\hline $\mathrm{K}_{2} \mathrm{O}$ & 1.2 & & \\
\hline $\mathrm{H}_{2} \mathrm{O}^{*}$ & 15.9 & 8.35 & 8.35 \\
\hline $\mathrm{SUM}$ & 100 & 100 & 100 \\
\hline
\end{tabular}

* measured at $105^{\circ} \mathrm{C}$

Particle size analysis of the Decalso and IE-95 were performed and the results are tabluated in Table VIII.

The bulk density of the IE-95 zeolite was measured by weighing 10cc of IE-95 from a graduated cylinder after the contents had been lightly tamped down. A density of 0.791 $\mathrm{g} / \mathrm{cc}$ was measured which converts to a density of $6.58 \mathrm{lbs} / \mathrm{gal}$ according to the following formula

$$
(0.791 \mathrm{~g} / \mathrm{cc}) *(1 \mathrm{~kg} / 1000 \mathrm{~g}) *(1000 \mathrm{cc} / 1 \mathrm{~L}) *(3.78 \mathrm{~L} / \mathrm{gal}) *(2.2 \mathrm{lbs} / \mathrm{kg})=6.58 \mathrm{lbs} / \mathrm{gal} \text {. }
$$

The $6.58 \mathrm{lbs/gal} \mathrm{bulk} \mathrm{density} \mathrm{measured} \mathrm{in} \mathrm{this} \mathrm{study} \mathrm{is} \mathrm{consistent} \mathrm{with,} \mathrm{albeit} \mathrm{slightly}$ higher, than the density of $6 \mathrm{lbs} /$ gal used in $1979^{2}$ to convert gallons of zeolite to pounds. The $6.58 \mathrm{lbs} / \mathrm{gal}$ also agrees well with the bulk density analysis of unreacted zeolite performed by Swingle ${ }^{15}$ in calibrated centrifuge tubes, which gave a bulk density of 7.09lbs/gal, somewhat higher than the bulk density measured in this study. 
A second sample of unreacted IE-95 was measured by air pycnometry which provides the density of the mineral mixture and does not consider void volume. Duplicate measurements of the IE-95 mineral density gave a density of $2.28 \mathrm{~g} / \mathrm{cc}$. This mineral density is not converted to lbs/gal since the sample would have to be completely compacted with no void space in order for the density in lbs/gal to be meaningful. The mineral density was, however, necessary to convert the particle size analyses given in Table VIII from measured wt $\%$ of a given sieve size to vol \% so that analyses performed with the Microtrac particle size analyzer could be compared to larger particle size analysis measured by sieving.

\subsection{Weight Loss and Particle Size of Tank 19F Solids Compared to IE-95 and Decalso}

Comparison of the composition of the Tank 19F crusty mound sample (FTF-024) given in Table I and Table $\mathrm{V}$ indicate that the mound is made up of a mixture of sludge and converted IE-95 ion exchange media. The presence of $8.6 \mathrm{wt} \% \mathrm{NO}_{3}{ }^{-}$confirms the XRD analyses that a nitrated sodalite or nitrated cancrinite are present. If all of the $\mathrm{Si}$ in the mound sample is attributable to the nitrated sodalite, then as much as $60-80 \mathrm{wt} \%$ of the mound may be converted IE-95 resin.

A comparison of the weight loss upon drying (Table VII) at various temperatures based on the measurements for the Tank $19 \mathrm{~F}$ mound sample and the weight loss of the unreacted ion exchange media (Decalso and IE-95) is shown in Figure 5. The weight loss of the Tank $19 \mathrm{~F}$ mound sample is less than the weight loss of either of the starting ion exchange media before aging in tank solutions. The significance of this will be discussed in more detail in Section 6.0.

The ordinary least squares (OLS) regressions for each of the curves in Figure 5 are as follows:

$$
\begin{array}{lll}
(\mathrm{Wt} \text { loss \% })_{\text {Decalso }}=14.14+0.0045 \mathrm{Temp}^{\circ} \mathrm{C} & \mathrm{R}^{2}=0.99 & \text { [Eq. 1] } \\
(\mathrm{Wt} \text { loss \% })_{\text {IE-95 }}=9.15+0.0073 \mathrm{Temp}{ }^{\circ} \mathrm{C} & \mathrm{R}^{2}=0.99 & \text { [Eq. 2] } \\
(\mathrm{Wt} \text { loss \% })_{\mathrm{T} 19}=3.03+0.0121 \mathrm{Temp}{ }^{\circ} \mathrm{C} & \mathrm{R}^{2}=0.99 & \text { [Eq. 3] }
\end{array}
$$




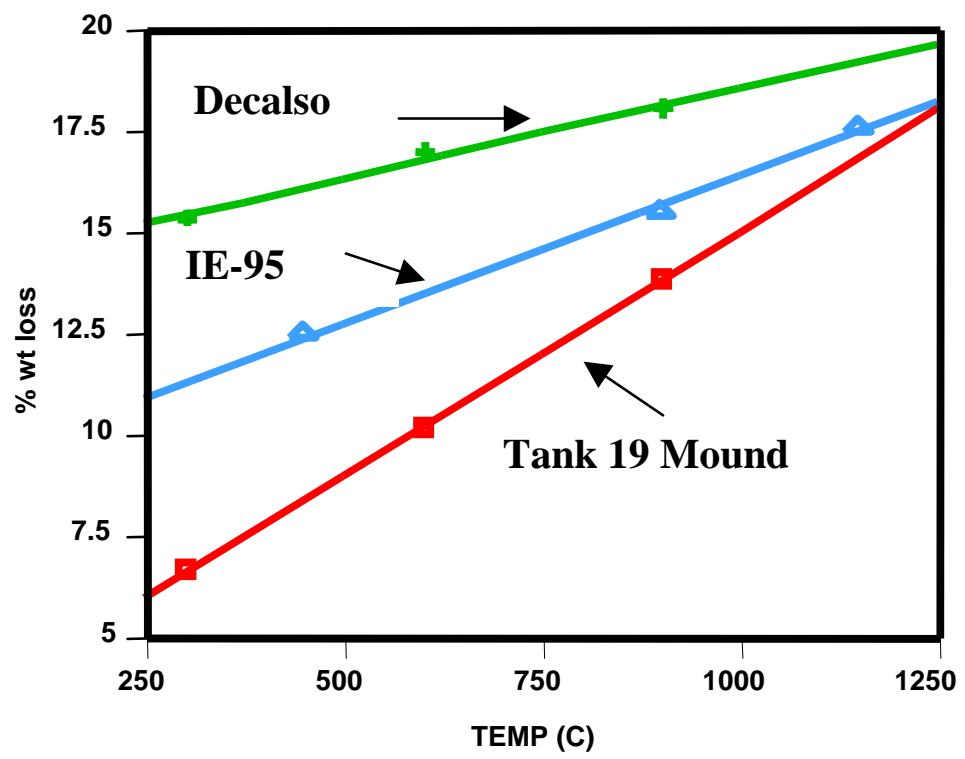

Figure 5 Comparison of the weight loss upon calcining of the Tank 19F mound sample and unreacted ion exchange media (Decalso and IE-95).

A comparison of the particle size analysis from Table VIII for the Tank 19F mound sample and the ion exchange media (Decalso and IE-95) is shown in Figure 6. The particle size ranges of both the mound material and the unreacted ion exchange media exhibit gaussian distributions. The Tank 19F mound material size distribution is skewed to lower particle sizes, e.g. exhibits a tail in the region between 0 and $100 \mu \mathrm{m}$. The maximum volume \% of the Gaussian distribution is at $~ 500 \mu \mathrm{m}$. While the Decalso particle size distribution does not show the small particle size tail exhibited by the Tank 19F mound particles, the maximum volume \% also occurs close to $500 \mu \mathrm{m}$. By comparison, the IE-95 particle size maximum volume \% occurs close to $1000 \mu \mathrm{m}$ or 1 $\mathrm{mm}$ as reported in Reference 2. It is noteworthy that the particle size distribution for the IE-95 has the same small particle size tail exhibited by the Tank 19F mound sample, albeit at larger particle sizes. This indicates that the Tank 19F material is indeed the IE95 that during aging in tank solutions has uniformly converted to a mineral phase with approximately $1 / 2$ of its original size. 


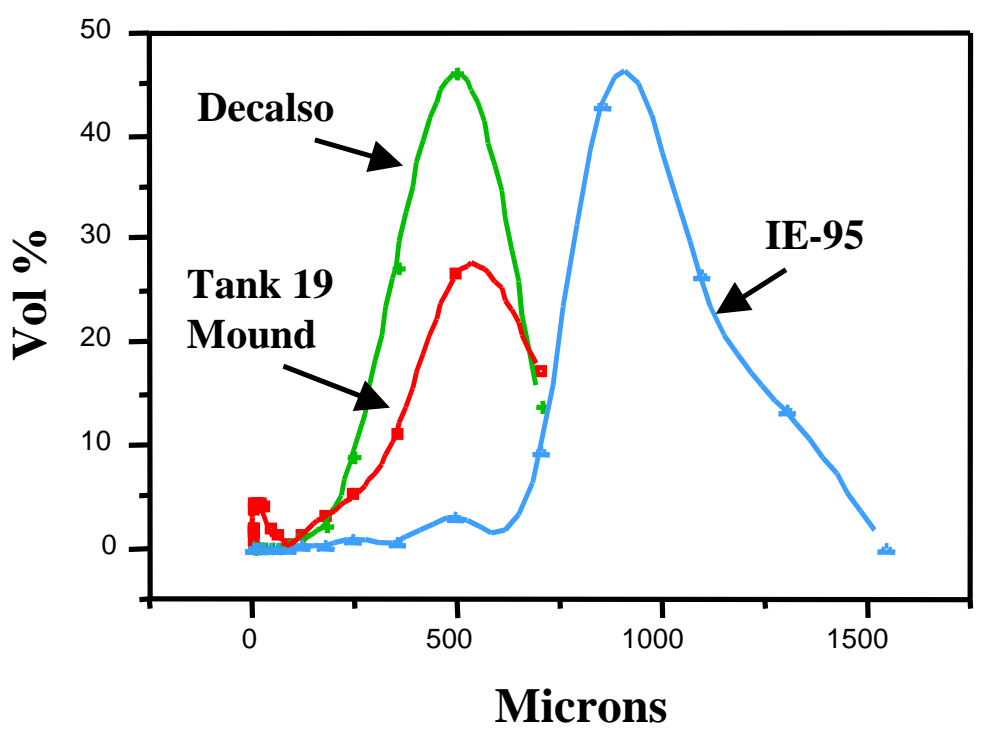

Figure 6. Comparison of the particle size of the Tank 19F mound sample and unreacted ion exchange media (Decalso and IE-95). 


\subsection{ZEOLITE AGING MECHANISMS}

From the analysis of the Tank 19F mound sample, the chabazite, erionite, and clay in the unreacted IE-95 (Figure 1) appear to have converted to nitrated sodalite and hydroxycancrinite (Figure 2). A brief look at this transformation from a crystallographic viewpoint, as shown in Figure 7, indicates that the elongated hexagonal/rhombohedral structures of chabazite and erionite have collapsed to smaller unit cell sizes of a simpler crystallographic space groups (cubic and hexagonal). However, the 6 membered rings of $(\mathrm{Si}, \mathrm{Al}) \mathrm{O}_{4}$ tetrahedra which comprise the framework of the chabazite and erionite are retained in the sodalite and cancinite structures. In the sodalite structure some of the 6 membered ( $\mathrm{Si}, \mathrm{Al}) \mathrm{O}_{4}$ tetrahedral rings have collapsed to 4 membered ( $\left.\mathrm{Si}, \mathrm{Al}\right) \mathrm{O}_{4}$ rings. In addition, the more open cage like structures of the chabazite and erionite contained crystallographic sites that could accommodate 12 to 72 waters of hydration per unit cell. The reaction product sodalite has no waters of hydration and the cancrinite has only four waters of hydration per unit cell. Concomitant with the structural rearrangement and dehydration is an increase in the density of the resulting reaction products even though they are in an aqueous solution.

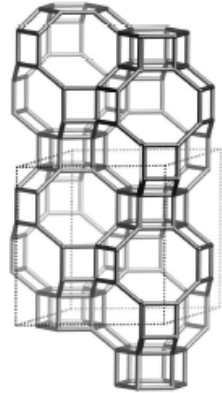

Chabazite

$r=2.04$

$12 \mathrm{H}_{2} \mathrm{O}$

rings of

6(Si,Al) $\mathrm{O}_{4}$

Rhombohedral

(Hexagonal)

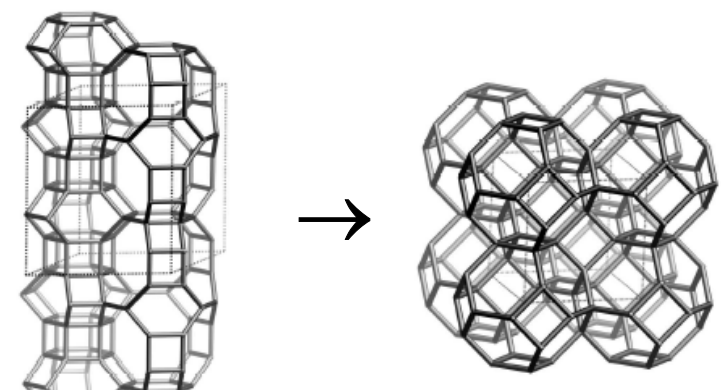

Sodalite

$r=2.38$

rings of $4+6(\mathrm{Si}, \mathrm{Al}) \mathrm{O}_{4}$

(Cubic)

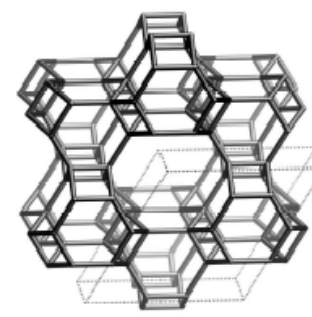

Cancrinite

$r=2.59$

$4 \mathrm{H}_{2} \mathrm{O}$ rings of $6(\mathrm{Si}, \mathrm{Al}) \mathrm{O}_{4}$

(Hexagonal)

Figure 7. Structural morphology of the transformation of chabazite and erionite to sodalite and cancrinite. 
The aging of zeolites to denser more stable phases by Ostwald ripening is a well known $^{20}$, phemomena. ${ }^{f}$ Phases age by densifying and dewatering to minerals that are more stable than their hydrous analgoues. The aging of zeolites to their structurally related feldspathoid minerals, the sodalites and cancrinites, is also a well known and well-understood phenomena. ${ }^{21,22}$ Ostwald's rule of successive transformation demonstrates that the products found at the longest times represent phases which are thermodynamically more stable under the synthesis conditions than their predecessors. ${ }^{20}$ This is in agreement with the known fact that zeolites of the chabzite type $\left(\mathrm{Al}_{2} \mathrm{O}_{3}: 8 \mathrm{SiO}_{2}\right)$ are the stable phase in $\sim 200 \%$ excess $\mathrm{NaOH}$ while the denser dewatered sodalites $\left(\mathrm{Al}_{2} \mathrm{O}_{3}: 2 \mathrm{SiO}_{2}\right)$ are the stable phase in $\geq 300 \%$ excess $\mathrm{NaOH}$ at temperatures $\leq 100^{\circ} \mathrm{C}^{20}$

\subsection{Tank 19F Sample Verification}

Verification that the dewatering/densification reaction

$$
50 \% \text { chabazite }+30 \% \text { erionite }+20 \% \text { clay } \rightarrow \text { sodalite }+ \text { cancrinite } \quad \text { [ Eq. } 4]
$$

is the operative mechanism by which IE-95 converted to sodalite/cancrinite in SRS waste tanks can be gathered by comparing the water weight loss of the IE-95 and the Tank 19F mound material at the tank temperature of $\sim 40^{\circ} \mathrm{C}$. The reaction shown in Equation 4 indicates that the left hand side (LHS) has the following numbers of hydrated water molecules:

$$
\begin{gathered}
0.3 * 23 \text { moles } \mathrm{H}_{2} \mathrm{O}+0.5 * 12 \text { moles } \mathrm{H}_{2} \mathrm{O}+0.2 * 4 \text { moles } \mathrm{H}_{2} \mathrm{O}=13.7 \mathrm{H}_{2} \mathrm{O} * 18 \mathrm{~g} / \mathrm{mole}= \\
246 \mathrm{~g} \mathrm{H}_{2} \mathrm{O}
\end{gathered}
$$

while the right hand side (RHS) only has $1 * 4$ moles $\mathrm{H}_{2} \mathrm{O} * 18 \mathrm{~g} /$ mole $=72$ grams $\mathrm{H}_{2} \mathrm{O}$. The difference between the LHS and the RHS is $174 \mathrm{~g} \mathrm{H}_{2} \mathrm{O} / \mathrm{mole}$ of IE-95 that is $71 \mathrm{wt} \%$ of the total water on the LHS of Equation 4. For comparison, if Equations 2 and 3 are solved at the tank temperature of $40^{\circ} \mathrm{C}$, the difference in weight loss between these two equations, divided by the weight loss of the unconverted IE-95, is $63 \mathrm{wt} \%$. The comparison of the theoretical water loss of $71 \mathrm{wt} \%$ to the experimentally determined Tank 19F mound loss of $\sim 63 \mathrm{wt} \%$ is confirmatory of the proposed mechanism.

Another way in which Equation 4 can be verified is to examine a parameter known as the framework density. The framework density for silicate minerals ${ }^{23}$ is given by

$$
d_{f}=\frac{1000 n_{T}}{V_{\text {cell }}}
$$

${ }^{f}$ According to Ostwald's rule, in the formation of polymorphs of a given compound, the first polymorph to be formed from vapour, liquid or solution tends to be the least stable thermodynamically which is then in succession replaced by more and more stable polymorphs ${ }^{20}$ 
where $d_{f}=$ framework density, $n_{T}=$ number of tetrahedral atoms in $1000 \AA^{3}$ of the unit cell, and $\mathrm{V}_{\text {cell }}=$ volume of the crystallographic cell.

The calculated $\mathrm{d}_{\mathrm{f}}$ for chabazite found in the virgin IE-95 is 4.86 while that of erionite is 15.69. The calculated framework densities for nitrated sodalite and hydroxy-cancrinite, found in the Tank 19F mound are 16.58 and 16.64 respectively. Therefore, the combined densification and dehydration reactions given in Equation 4 are operative in the aqueous SRS tank environments.

\subsection{Simulant Verification}

In order to examine the mechanism by which IE-95 converts from chabazite, erionite, and clay to nitrated sodalite and hydroxy-cancrinite, laboratory experiments with simulants were performed. Virgin IE-95 was placed in 5M and 10M NaOH. The IE-95 samples were placed in an oven at $90^{\circ} \mathrm{C}$ for varying amounts of time. Slightly elevated temperatures were used to enhance the rate of reaction although Tank 19F has reportedly ${ }^{4}$ seen maximum temperatures of $80^{\circ} \mathrm{C}$. Samples were left in the oven for 2 day, 5 day, 7 day, 14 day, 21 day, and 28 day time durations.

After only 2 days in 10M NaOH, the virgin IE-95 had broken down into smaller platelets consistent with the particle size analyses shown in Figure 12. The reacted particles were covered with a gelatinous material which was removed during washing in deionized water (Figure 8). After 7 days in $10 \mathrm{M} \mathrm{NaOH}$, the gelatinous coating on the IE-95 has turned a milky white color (Figure 9). However, after washing this coating off the sample, what appears to be unreacted IE-95 again became apparent. Analysis by XRD before and after washing the reacted particles demonstrated that the gelatinous coating was various carbonate species such as calcite $(\mathrm{Ca}, \mathrm{Mg}) \mathrm{CO}_{3}$, natronite $\left(\mathrm{Na}_{2} \mathrm{CO}_{3}\right)$, and thermonatrite $\left(\mathrm{Na}_{2} \mathrm{CO}_{3} \bullet \mathrm{H}_{2} \mathrm{O}\right)$ as shown in Table X. These phases are water soluble and are not apparent in the XRD spectra of the washed samples of IE-95. Conversely, the reaction product $\mathrm{SiO}_{2}$ only appears in the washed samples after the gelatinous, presumably, amorphous $\mathrm{SiO}_{2}$ is washed away (Table X). 

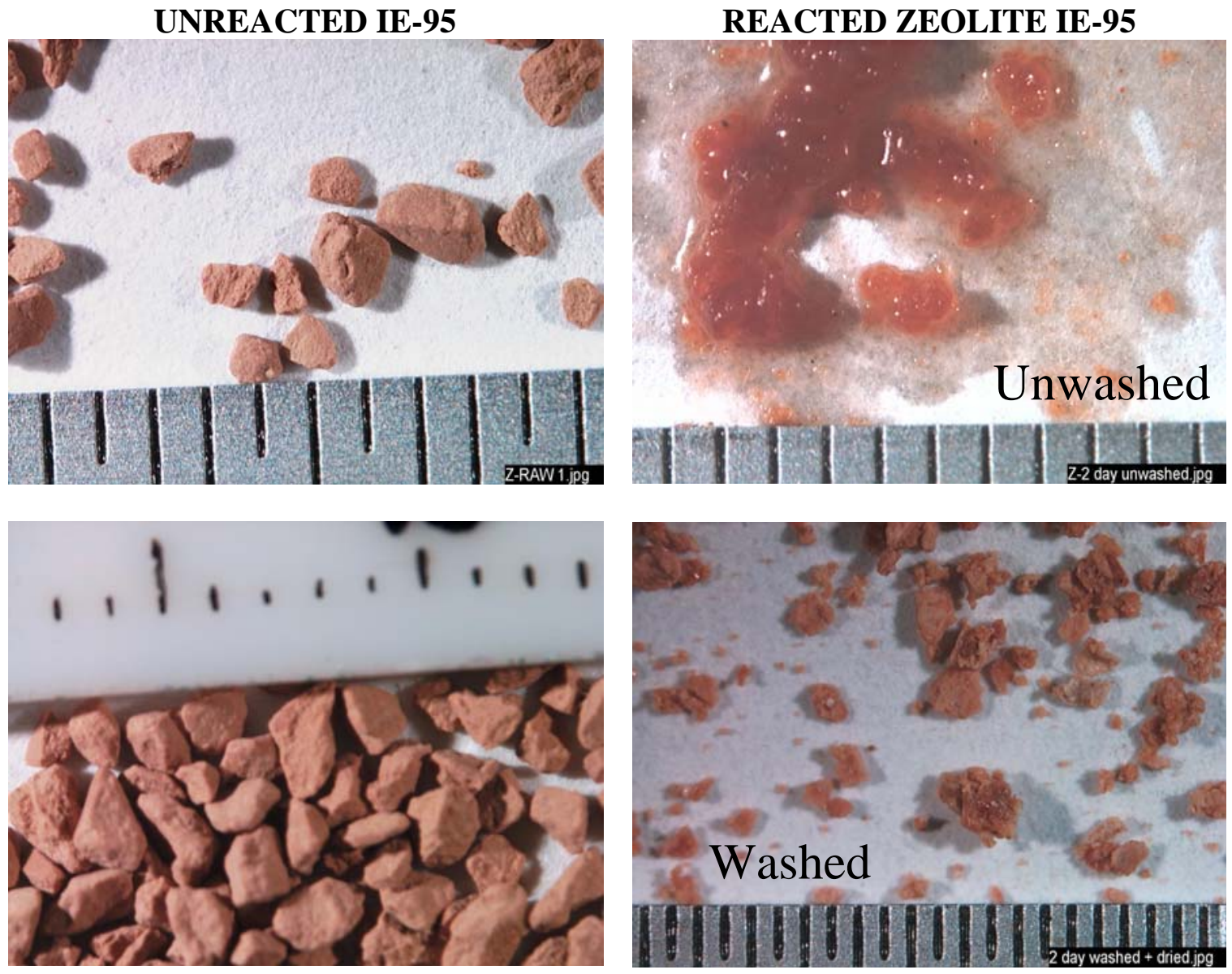

Figure 8. IE-95 before and after reaction with $10 \mathrm{M} \mathrm{NaOH}$ at $90^{\circ} \mathrm{C}$ for 2 days. Steel ruler markings are $0.5 \mathrm{~mm}$.
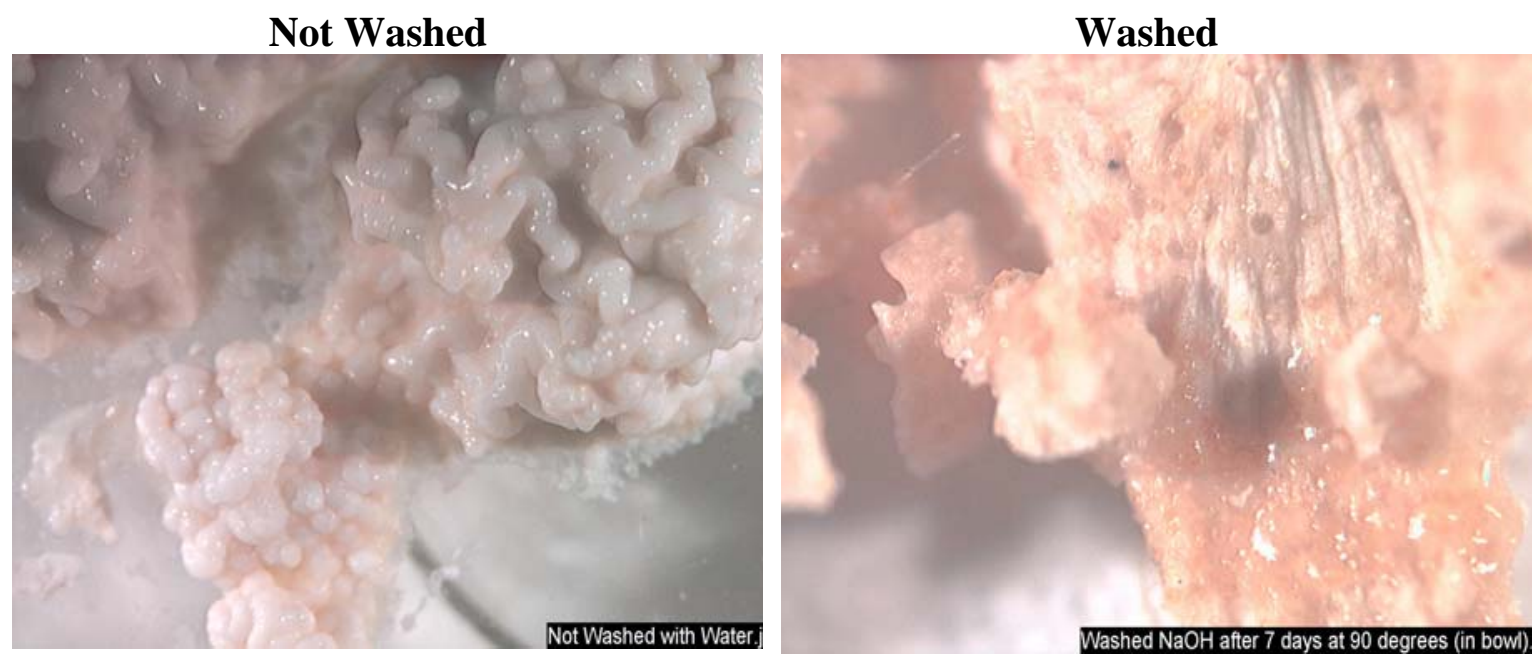

Figure 9. IE-95 after reaction with $10 \mathrm{M} \mathrm{NaOH}$ at $90^{\circ} \mathrm{C}$ for 7 days. 
Table X Conversion of IE-95 to Other Mineral Phases in the Presence of $\mathrm{NaOH}$ and CsOH

\begin{tabular}{|c|c|c|c|c|c|c|}
\hline $\begin{array}{c}\text { Time } \\
\text { (days) }\end{array}$ & $\begin{array}{c}\text { IE-95 } \\
\text { 10M } \\
\text { NaOH } \\
\text { Not Washed }\end{array}$ & $\begin{array}{c}\text { IE-95 } \\
\text { 5M } \\
\text { NaOH } \\
\text { Not Washed }\end{array}$ & $\begin{array}{c}\text { IE-95 } \\
\text { 10M } \\
\text { NaOH } \\
\text { Washed }\end{array}$ & $\begin{array}{c}\text { IE-95 } \\
\text { 5M } \\
\text { NaOH } \\
\text { Washed }\end{array}$ & $\begin{array}{c}\text { IE-95 } \\
\text { 10M } \\
\text { CsOH } \\
\text { Not Washed }\end{array}$ & $\begin{array}{c}\text { IE-95 } \\
\text { 10M } \\
\text { CsOH } \\
\text { Washed }\end{array}$ \\
\hline 2 & $\begin{array}{l}\mathrm{Na}_{8} \mathrm{Al}_{6} \mathrm{Si}_{6} \mathrm{O}_{24}(\mathrm{OH})_{2}\left(\mathrm{H}_{2} \mathrm{O}\right)_{2} \\
+\mathrm{Na}_{2} \mathrm{CO}_{3}+(\mathrm{Ca}, \mathrm{Mg}) \mathrm{CO}_{3}\end{array}$ & $\begin{array}{l}\mathrm{Na}_{8} \mathrm{Al}_{6} \mathrm{Si}_{6} \mathrm{O}_{24}(\mathrm{OH})_{2}\left(\mathrm{H}_{2} \mathrm{O}\right)_{2} \\
+\mathrm{Na}_{8} \mathrm{Al}_{6} \mathrm{Si}_{6} \mathrm{O}_{24} \mathrm{CO}_{3}+ \\
\mathrm{SiO}_{2}\end{array}$ & $\begin{array}{l}\mathrm{Na}_{8} \mathrm{Al}_{6} \mathrm{Si}_{6} \mathrm{O}_{24}(\mathrm{OH})_{2}\left(\mathrm{H}_{2} \mathrm{O}\right)_{2}+ \\
\mathrm{Na}_{8} \mathrm{Al}_{6} \mathrm{Si}_{6} \mathrm{O}_{24}\left(\mathrm{H}_{0.88} \mathrm{CO}_{3}\right)_{1.44}\left(\mathrm{H}_{2} \mathrm{O}\right)_{2} \\
+\mathrm{SiO}_{2}\end{array}$ & $\begin{array}{l}\mathrm{Na}_{8} \mathrm{Al}_{6} \mathrm{Si}_{6} \mathrm{O}_{24}(\mathrm{OH})_{2}\left(\mathrm{H}_{2} \mathrm{O}\right)_{2}+ \\
\mathrm{Na}_{8} \mathrm{Al}_{6} \mathrm{Si}_{6} \mathrm{O}_{24}\left(\mathrm{H}_{0.88} \mathrm{CO}_{3}\right)_{1.44}\left(\mathrm{H}_{2} \mathrm{O}\right)_{2} \\
+\mathrm{SiO}_{2}\end{array}$ & Not tested & Not tested \\
\hline 5 & $\begin{array}{l}\mathrm{Na}_{8} \mathrm{Al}_{6} \mathrm{Si}_{6} \mathrm{O}_{24}(\mathrm{OH})_{2}\left(\mathrm{H}_{2} \mathrm{O}\right)_{2} \\
+\mathrm{Na}_{2} \mathrm{CO}_{3}+(\mathrm{Ca}, \mathrm{Mg}) \mathrm{CO}_{3} \\
+\mathrm{Na}_{2} \mathrm{CO}_{3} \bullet \mathrm{H}_{2} \mathrm{O}\end{array}$ & $\mathrm{Na}_{8} \mathrm{Al}_{6} \mathrm{Si}_{6} \mathrm{O}_{24}(\mathrm{OH})_{2}\left(\mathrm{H}_{2} \mathrm{O}\right)_{2}$ & $\begin{array}{l}\mathrm{Na}_{8} \mathrm{Al}_{6} \mathrm{Si}_{6} \mathrm{O}_{24}(\mathrm{OH})_{2}\left(\mathrm{H}_{2} \mathrm{O}\right)_{2}+ \\
\mathrm{Na}_{8} \mathrm{Al}_{6} \mathrm{Si}_{6} \mathrm{O}_{24}\left(\mathrm{H}_{0.88} \mathrm{CO}_{3}\right)_{1.44}\left(\mathrm{H}_{2} \mathrm{O}\right)_{2} \\
+\mathrm{SiO}_{2}\end{array}$ & $\begin{array}{l}\mathrm{Na}_{8} \mathrm{Al}_{6} \mathrm{Si}_{6} \mathrm{O}_{24}(\mathrm{OH})_{2}\left(\mathrm{H}_{2} \mathrm{O}\right)_{2}+ \\
\mathrm{Na}_{8} \mathrm{Al}_{6} \mathrm{Si}_{6} \mathrm{O}_{24}\left(\mathrm{H}_{0.88} \mathrm{CO}_{3}\right)_{1.44}\left(\mathrm{H}_{2} \mathrm{O}\right)_{2} \\
+\mathrm{SiO}_{2}\end{array}$ & Not tested & Not tested \\
\hline 7 & $\begin{array}{l}\mathrm{Na}_{8} \mathrm{Al}_{6} \mathrm{Si}_{6} \mathrm{O}_{24}(\mathrm{OH})_{2}\left(\mathrm{H}_{2} \mathrm{O}\right)_{2} \\
+(\mathrm{Ca}, \mathrm{Mg}) \mathrm{CO}_{3}+ \\
\mathrm{Na}_{2} \mathrm{CO}_{3} \bullet \mathrm{H}_{2} \mathrm{O}\end{array}$ & $\begin{array}{l}\mathrm{Na}_{8} \mathrm{Al}_{6} \mathrm{Si}_{6} \mathrm{O}_{24}(\mathrm{OH})_{2}\left(\mathrm{H}_{2} \mathrm{O}\right)_{2} \\
+\mathrm{Na}_{8} \mathrm{Al}_{6} \mathrm{Si}_{6} \mathrm{O}_{24} \mathrm{CO}_{3}+ \\
\mathrm{SiO}_{2}\end{array}$ & $\begin{array}{l}\mathrm{Na}_{8} \mathrm{Al}_{6} \mathrm{Si}_{6} \mathrm{O}_{24}(\mathrm{OH})_{2}\left(\mathrm{H}_{2} \mathrm{O}\right)_{2}+ \\
\mathrm{Na}_{8} \mathrm{Al}_{6} \mathrm{Si}_{6} \mathrm{O}_{24}\left(\mathrm{H}_{0.88} \mathrm{CO}_{3}\right)_{1.44}\left(\mathrm{H}_{2} \mathrm{O}\right)_{2} \\
+\mathrm{SiO}_{2}\end{array}$ & $\begin{array}{l}\mathrm{Na}_{8} \mathrm{Al}_{6} \mathrm{Si}_{6} \mathrm{O}_{24}(\mathrm{OH})_{2}\left(\mathrm{H}_{2} \mathrm{O}\right)_{2}+ \\
\mathrm{Na}_{8} \mathrm{Al}_{6} \mathrm{Si}_{6} \mathrm{O}_{24}\left(\mathrm{H}_{0.88} \mathrm{CO}_{3}\right)_{1.44}\left(\mathrm{H}_{2} \mathrm{O}\right)_{2} \\
+\mathrm{SiO}_{2}\end{array}$ & $\begin{array}{l}\mathrm{Cs}_{3} \mathrm{Ca}_{0.4} \mathrm{Al}_{3.8} \mathrm{Si}_{8 \cdot 3} \mathrm{O}_{24} \\
\text { (Cs Chabazite) }\end{array}$ & $\begin{array}{l}\mathrm{Cs}_{3} \mathrm{Ca}_{0.4} \mathrm{Al}_{3.8} \mathrm{Si}_{8 \cdot 3} \mathrm{O}_{24}(\mathrm{Cs} \\
\text { Chabazite) + CsAlSi } \mathrm{O}_{6} \\
\text { (Pollucite) }\end{array}$ \\
\hline 14 & $\begin{array}{l}\mathrm{Na}_{8} \mathrm{Al}_{6} \mathrm{Si}_{6} \mathrm{O}_{24}(\mathrm{OH})_{2}\left(\mathrm{H}_{2} \mathrm{O}\right)_{2} \\
+ \text { Chabazite }+\mathrm{Na}_{2} \mathrm{CO}_{3}+ \\
\text { Vermiculite }\end{array}$ & $\begin{array}{l}\mathrm{Na}_{8} \mathrm{Al}_{6} \mathrm{Si}_{6} \mathrm{O}_{24}(\mathrm{OH})_{2}\left(\mathrm{H}_{2} \mathrm{O}\right)_{2} \\
+\mathrm{Na}_{8} \mathrm{Al}_{6} \mathrm{Si}_{6} \mathrm{O}_{24} \mathrm{CO}_{3}\end{array}$ & $\mathrm{Na}_{8} \mathrm{Al}_{6} \mathrm{Si}_{6} \mathrm{O}_{24}(\mathrm{OH})_{2}\left(\mathrm{H}_{2} \mathrm{O}\right)_{2}+\mathrm{SiO}_{2}$ & $\begin{array}{l}\mathrm{Na}_{8} \mathrm{Al}_{6} \mathrm{Si}_{6} \mathrm{O}_{24}(\mathrm{OH})_{2}\left(\mathrm{H}_{2} \mathrm{O}\right)_{2}+ \\
\mathrm{Na}_{8} \mathrm{Al}_{6} \mathrm{Si}_{6} \mathrm{O}_{24}\left(\mathrm{H}_{0.88} \mathrm{CO}_{3}\right)_{1.44}\left(\mathrm{H}_{2} \mathrm{O}\right)_{2}\end{array}$ & Not tested & Not tested \\
\hline 21 & $\begin{array}{l}\mathrm{Na}_{8} \mathrm{Al}_{6} \mathrm{Si}_{6} \mathrm{O}_{24}(\mathrm{OH})_{2}\left(\mathrm{H}_{2} \mathrm{O}\right)_{2} \\
+\mathrm{Na}_{2} \mathrm{CO}_{3}+\text { Zeolite } \mathrm{Y}+ \\
\text { Chabazite }\end{array}$ & $\begin{array}{l}\mathrm{Na}_{8} \mathrm{Al}_{6} \mathrm{Si}_{6} \mathrm{O}_{24}(\mathrm{OH})_{2}\left(\mathrm{H}_{2} \mathrm{O}\right)_{2} \\
+\mathrm{Na}_{8} \mathrm{Al}_{6} \mathrm{Si}_{6} \mathrm{O}_{24} \mathrm{CO}_{3}\end{array}$ & $\mathrm{Na}_{8} \mathrm{Al}_{6} \mathrm{Si}_{6} \mathrm{O}_{24}(\mathrm{OH})_{2}\left(\mathrm{H}_{2} \mathrm{O}\right)_{2}$ & $\begin{array}{l}\mathrm{Na}_{8} \mathrm{Al}_{6} \mathrm{Si}_{6} \mathrm{O}_{24}(\mathrm{OH})_{2}\left(\mathrm{H}_{2} \mathrm{O}\right)_{2}+ \\
\mathrm{Na}_{8} \mathrm{Al}_{6} \mathrm{Si}_{6} \mathrm{O}_{24}\left(\mathrm{H}_{0.88} \mathrm{CO}_{3}\right)_{1.44}\left(\mathrm{H}_{2} \mathrm{O}\right)_{2} \\
+\mathrm{SiO}_{2}\end{array}$ & Not tested & Not tested \\
\hline 28 & $\begin{array}{l}\mathrm{Na}_{8} \mathrm{Al}_{6} \mathrm{Si}_{6} \mathrm{O}_{24}(\mathrm{OH})_{2}\left(\mathrm{H}_{2} \mathrm{O}\right)_{2} \\
+\mathrm{Na}_{2} \mathrm{CO}_{3}+(\mathrm{Ca}, \mathrm{Mg}) \mathrm{CO}_{3}\end{array}$ & $\begin{array}{l}\mathrm{Na}_{8} \mathrm{Al}_{6} \mathrm{Si}_{6} \mathrm{O}_{24}(\mathrm{OH})_{2}\left(\mathrm{H}_{2} \mathrm{O}\right)_{2} \\
+\mathrm{Na}_{2} \mathrm{CO}_{3}+\text { Zeolite } \mathrm{Y}+ \\
\text { Chabazite }\end{array}$ & $\mathrm{Na}_{8} \mathrm{Al}_{6} \mathrm{Si}_{6} \mathrm{O}_{24}(\mathrm{OH})_{2}\left(\mathrm{H}_{2} \mathrm{O}\right)_{2}+\mathrm{SiO}_{2}$ & $\begin{array}{l}\mathrm{Na}_{8} \mathrm{Al}_{6} \mathrm{Si}_{6} \mathrm{O}_{24}(\mathrm{OH})_{2}\left(\mathrm{H}_{2} \mathrm{O}\right)_{2}+\mathrm{SiO}_{2} \\
+\mathrm{CaCO}_{3}\end{array}$ & Not tested & Not tested \\
\hline & \multicolumn{6}{|c|}{$\begin{array}{ll}\text { PDF\# 76-1639 for Sodalite, } \mathrm{Na}_{8} \mathrm{Al}_{6} \mathrm{Si}_{6} \mathrm{O}_{24}(\mathrm{OH})_{2}\left(\mathrm{H}_{2} \mathrm{O}\right)_{2} & \text { PDF\#24-1045 for Sodalite, } \mathrm{Na}_{8} \mathrm{Al}_{6} \mathrm{Si}_{6} \mathrm{O}_{24} \mathrm{CO}_{3} \\
\text { PDF\#46-1045 for Quartz, } \mathrm{SiO}{ }_{2} & \text { PDF\#37-0451 for Natrite, } \mathrm{Na}_{2} \mathrm{CO}_{3} \\
\text { PDF \# 43-0697 for Magnesian Calcite, }(\mathrm{Ca}, \mathrm{Mg}) \mathrm{CO}_{3} & \text { PDF\#08-0448 for Thermonatrite, } \mathrm{Na}_{2} \mathrm{CO}_{3} \bullet \mathrm{H}_{2} \mathrm{O} \\
\text { PDF\#86-2226 for Chabazite, } \mathrm{Ca}_{1.85}\left(\mathrm{Al}_{3.7} \mathrm{Si}_{8.3} \mathrm{O}_{24}\right)\left(\mathrm{H}_{2} \mathrm{O}\right)_{7.6} & \text { PDF \# 16-0613 for Vermiculite, } \mathrm{Mg}_{\mathbf{x}}(\mathrm{Mg}, \mathrm{Fe})_{3}(\mathrm{Si}, \mathrm{Al})_{4} \mathrm{O}_{10}(\mathrm{OH})_{2} \bullet 4 \mathrm{H}_{2} \mathrm{O} \\
\text { PDF \# 38-0240 for Zeolite Y, } \mathrm{Na}_{2.06} \mathrm{Al}_{2} \mathrm{Si}_{3.8} \mathrm{O}_{11.63} \bullet 8 \mathrm{H}_{2} \mathrm{O} & \text { PDF\#77-1145 for Cancrinite, } \mathrm{Na}_{8} \mathrm{Al}_{6} \mathrm{Si}_{6} \mathrm{O}_{24}\left(\mathrm{H}_{0.88} \mathrm{CO}_{3}\right)_{1.44}\left(\mathrm{H}_{2} \mathrm{O}\right)_{2} \\
\text { PDF \# 44-046 for Cs Chabazite }\left(\mathrm{Cs}_{3} \mathrm{Ca}_{0.4} \mathrm{Al}_{3.8} \mathrm{Si}_{8 \cdot 3} \mathrm{O}_{24}\right) & \text { PDF \# 38-0240 for Zeolite Y }\left(\mathrm{Na}_{2.06} \mathrm{Al}_{2} \mathrm{Si}_{3.8} \mathrm{O}_{11.63} \bullet 8 \mathrm{H}_{2} \mathrm{O}\right)\end{array}$} \\
\hline
\end{tabular}


In addition, 5 grams of IE-95 were subjected to $10 \mathrm{M} \mathrm{CsOH}$ at $90^{\circ} \mathrm{C}$ for 7 days and 5 grams of Decalso was subjected to $10 \mathrm{M} \mathrm{NaOH}$ for 2 days at $90^{\circ} \mathrm{C}$. Half of the samples were washed with deionized water and half were left unwashed. The washed and unwashed samples were dried at $90^{\circ} \mathrm{C}$ overnight. The IE-95 reaction products were analyzed by XRD. The IE-95 in 10M CsOH converted to two cesium bearing minerals (see Table X), a Cs-substituted chabazite (the IE-95 is originally a Na, Ca chabazite) and pollucite $\left(\mathrm{CsAlSi}_{2} \mathrm{O}_{6}\right)$. The IE-95 reacted very little in the $\mathrm{CsOH}$. Each grain (washed and unwashed) had a light coating of a white reaction product (Figure 10). The Decalso reacted in $10 \mathrm{M} \mathrm{NaOH}$ for only 2 days, turned gelatinous like water glass and would not dry sufficiently so that $\mathrm{x}$-ray spectra could be obtained (Figure 11).
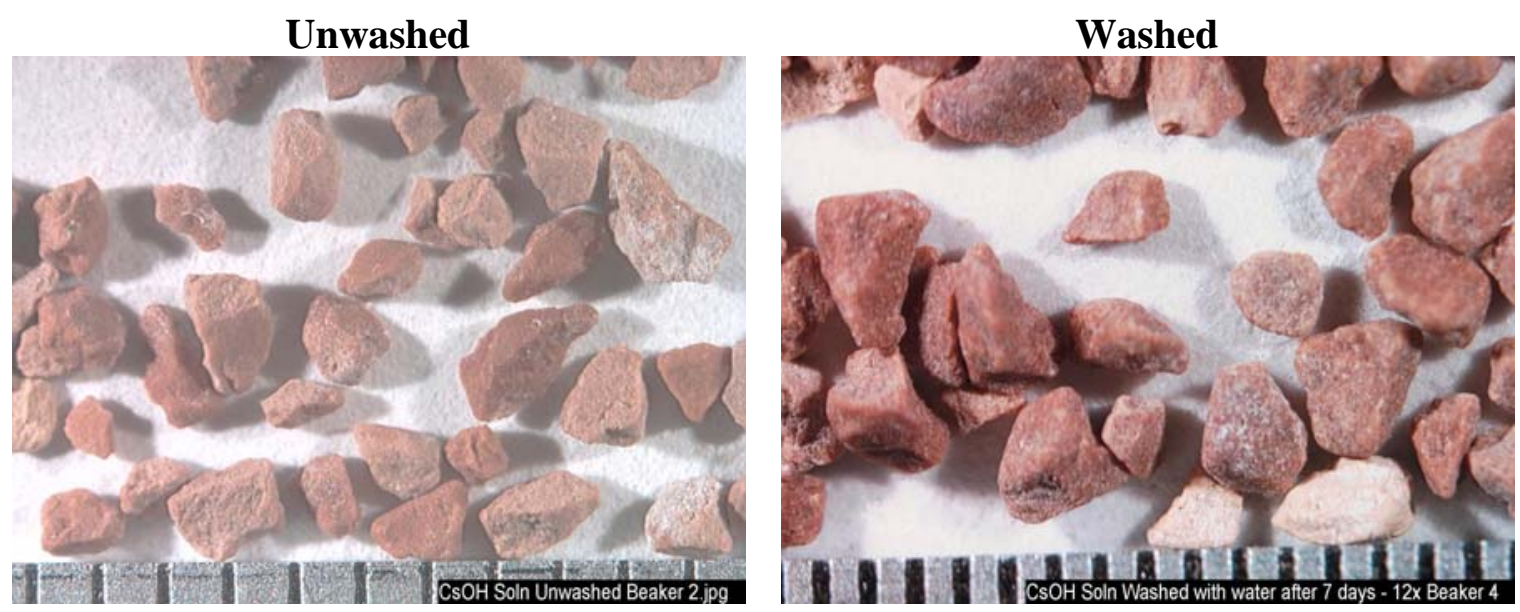

Figure 10. IE-95 reacted in $10 \mathrm{M} \mathrm{CsOH}$ for 7 days. Steel ruler markings are $0.5 \mathrm{~mm}$.
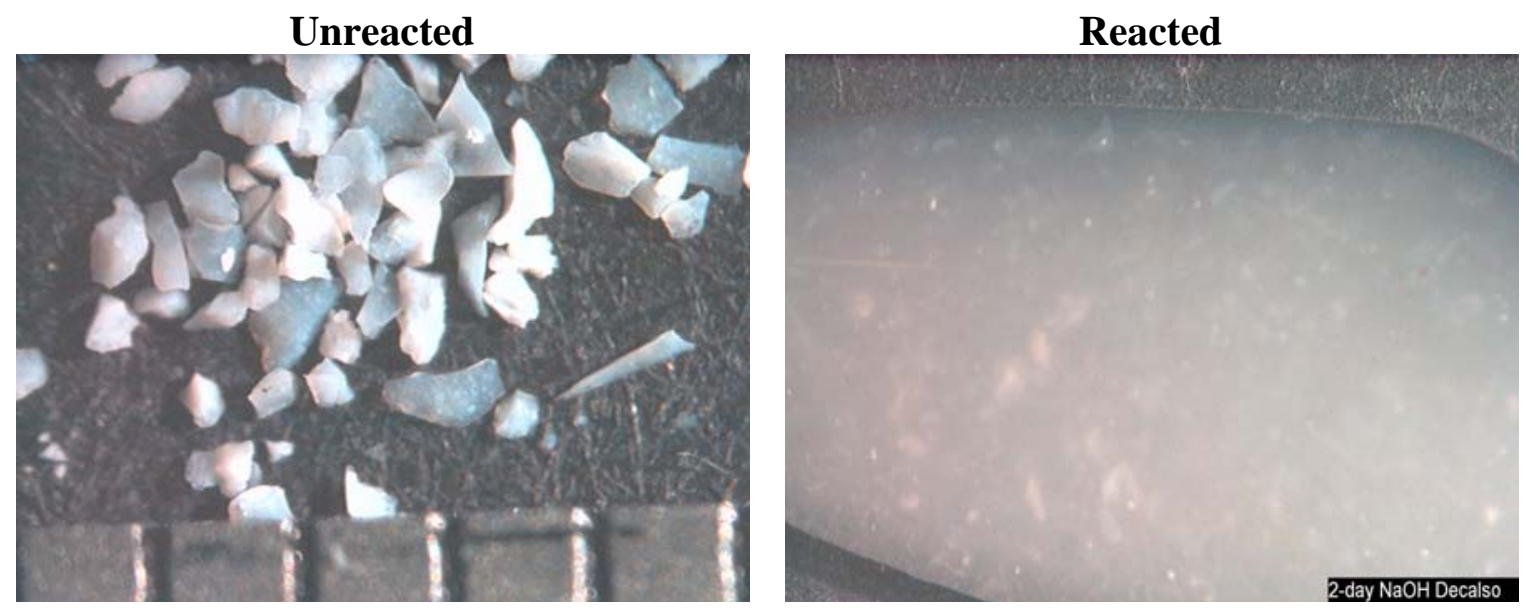

Figure 11. Decalso reacted in $10 \mathrm{M} \mathrm{NaOH}$ for 2 days. Steel ruler markings are $0.5 \mathrm{~mm}$. 


\subsection{ZEOLITE PARTICLE SIZE AND IMPACTS ON HYDRAGARD ${ }^{\circledR}$ SAMPLING IN DWPF}

The particle size distribution for the Tank 19F zeolite material is listed in Table VIII and plotted in Figure 6. This material was transferred to Tank 18F from Tank 19F and a portion of it was recently transferred to Tank 7F and onto Tank $51 \mathrm{H}$ where it has become part of SB3. The average particle size of $500 \mu \mathrm{m}$ shown in Figure 6 for the zeolite portion of the sludge indicates that there may be problems in operating the DWPF Hydragard $^{\circledR}$ samplers and in obtaining a representative sample of slurries containing this material. However, sieve analyses of Tank $51 \mathrm{H}$ sludge after receipt from Tank $18 \mathrm{~F}$ indicated only $0.04 \mathrm{wt} \%$ particulates over $38 \mu \mathrm{m} .{ }^{24}$ The $>38 \mu \mathrm{m}$ particles appear to be coal (black) and not zeolite. There are several potential reasons why zeolite particles as large as 500 um may not have been observed in the Tank $51 \mathrm{H}$ sludge:

- particles may have degraded in size during all the tank homogenization and transfers

- the Tank $51 \mathrm{H}$ sample sieved may not have been representative of the Tank $51 \mathrm{H}$ contents since the zeolite fraction is heavy and tends to differentially settle

- $\quad$ acid washing of the Tank $51 \mathrm{H}$ sample during sieving may have dissolved or reduced the size of the zeolite particles.

Sieve analyses of Tank 7F sludge after receipt from Tank 18F also did not indicate any particles over $106 \mu \mathrm{m}^{25}$ but the same acid washing procedure was used in all the sieve analyses which may have dissolved or degraded the zeolite particles.

Comparison of undegraded zeolite from Tank 19F to work conducted over the past several years evaluating the impact on the DWPF from implementing ion exchange using Crystalline Silicotitanate (CST) to remove cesium from the aqueous fraction of high level waste is shown in Figure 12. The spent CST resin would have been blended with sludge and glass formers (frit) in the DWPF. As part of this process, the slurry must be representatively sampled and the contents analyzed to ensure that acceptable glass product will be produced. Tests were conducted to assess the performance of the DWPF sampling system in the presence of CST particles which have a size distribution similar to that of the Tank19F zeolite. These tests demonstrated that the CST particles could not be accurately sampled without size reduction.

The DWPF melter feed is sampled using a Hydragard ${ }^{\circledR}$ sampling valve, which directs a stream of slurry into a $15 \mathrm{ml}$ "peanut" vial. The slurry is pumped out of the process tank and returned to the tank through a recirculation loop. The Hydragard ${ }^{\circledR}$ valve draws a side stream from this recirculation flow and directs the stream through the sampling valve. The stream flows through the sample vial and overflows into the recycle collection tank. After a preset time, usually 40 seconds, the Hydragard ${ }^{\circledR}$ valve is closed and a sample of the slurry trapped in the vial. Chemical analyses of these samples form the basis for glass quality assurance. Significant errors in the composition measurement may result in producing unacceptable glass product. 
The Hydragard ${ }^{\circledR}$ sampling system was designed to handle slurries of frit and sludge. Frit particles are in the size range of 80 to 200 mesh $(177-74 \mu \mathrm{m})$ while sludge particles are typically in the particle size range of $1-5$ microns or smaller. Testing during DWPF startup $^{26}$ verified that the recirculation loop and Hydragard ${ }^{\circledR}$ sampler worked satisfactorily for slurries with this particle size distribution. However, to obtain a workable pressure drop across the ion exchange column, the CST was engineered into a particle approximately $500-700 \mu \mathrm{m}$ in diameter. Initial testing ${ }^{27}$ using a mock-up of the DWPF Hydragard ${ }^{\circledR}$ sampling system with a melter feed of sludge simulant, frit, and approximately $10 \mathrm{wt} \%$ CST revealed that the Hydragard ${ }^{\circledR}$ sampler rapidly plugged because of the presence of the larger CST particles. As a result of these tests, it was evident that the particle size of spent CST resin must be reduced before blending with the DWPF sludge stream. As an initial estimate of the required particle size, it was decided that CST be size-reduced such that the maximum particle size is less than the largest frit particle which would likely provide both mixing and sampling properties adequate for processing in the DWPF. The testing was repeated with CST particles that were size reduced to a maximum size less than $177 \mu \mathrm{m}$ with satisfactory results. ${ }^{28}$

The particle size distribution of the Tank 19F mound material is compared to that of CST in Figure 12. Both distributions have an average particle size of about 500 microns and a significant fraction of the particles are greater than 177 microns in size. Figure 13 plots the cumulative distribution of particles for both materials. Because of the significant tail at smaller particle size, approximately $37 \%$ of the Tank $19 \mathrm{~F}$ material is less than 177 microns in size and could be accurately sampled with the DWPF Hydragard ${ }^{\circledR}$ system. However, the remaining $63 \%$ of the material would not be reliably sampled which could lead to some error in the estimation of the melter feed composition. With CST, sufficient size reduction did not occur during the DWPF process to allow use of as-received CST as DWPF feed material. ${ }^{28}$ The CST required mechanical size reduction to produce a feed material that could be representatively sampled by the DWPF Hydragard ${ }^{\circledR}$ system. 


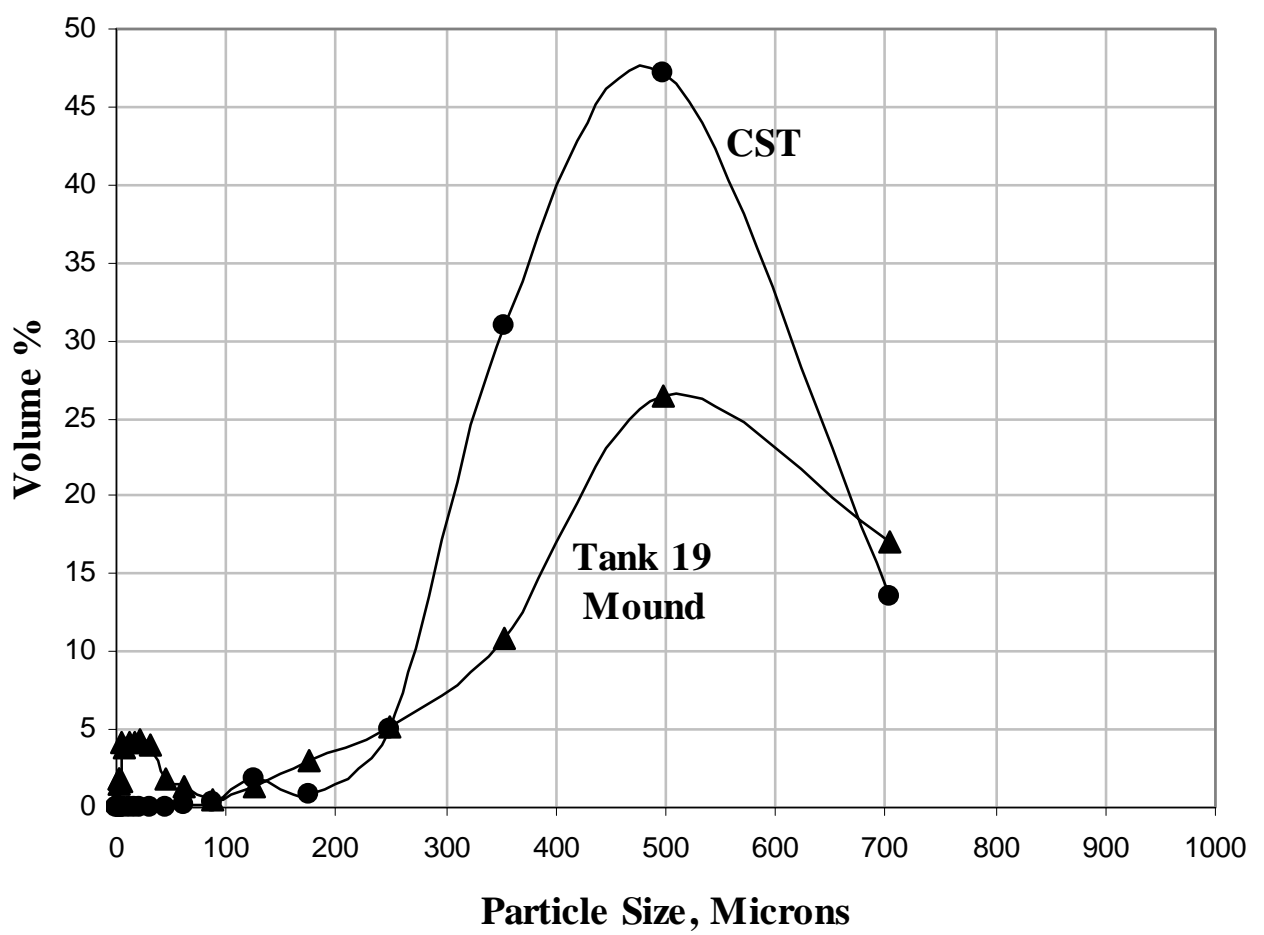

Figure 12. Particle size distributions of Tank19F mound material and CST. 
WSRC-TR-2002-00288, Rev. 0

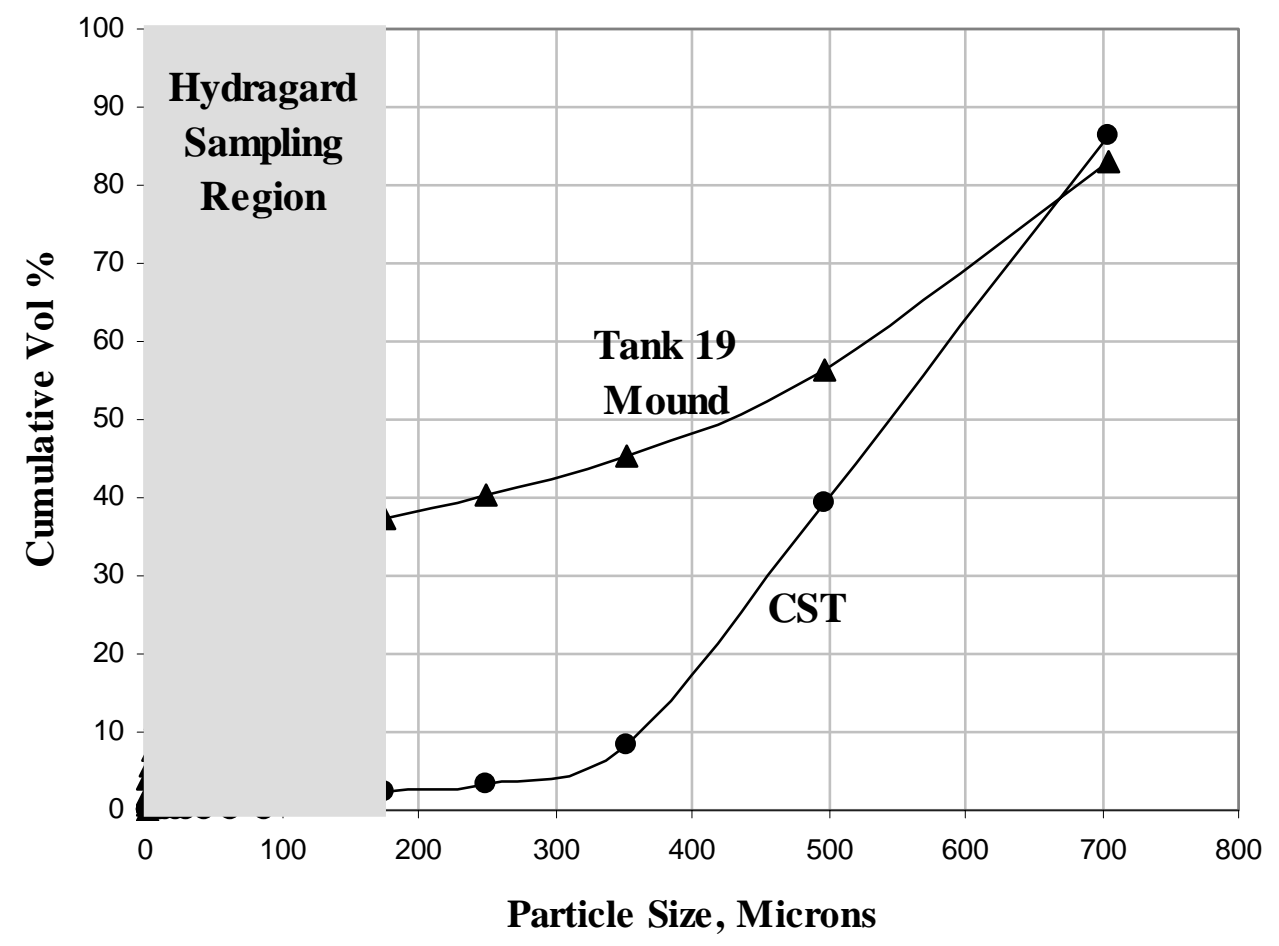

Figure 13. Cumulative particle size distributions of Tank19F mound material and CST. 


\subsection{ZEOLITE AGING MECHANISM AND IMPACTS ON SLUDGE WASHING}

The composition of the IE-95 is known ${ }^{16}$ to be $~ 50 \%$ chabazite, $30 \%$ erionite, and $20 \%$ clay binder of the compositions given in the equation below:

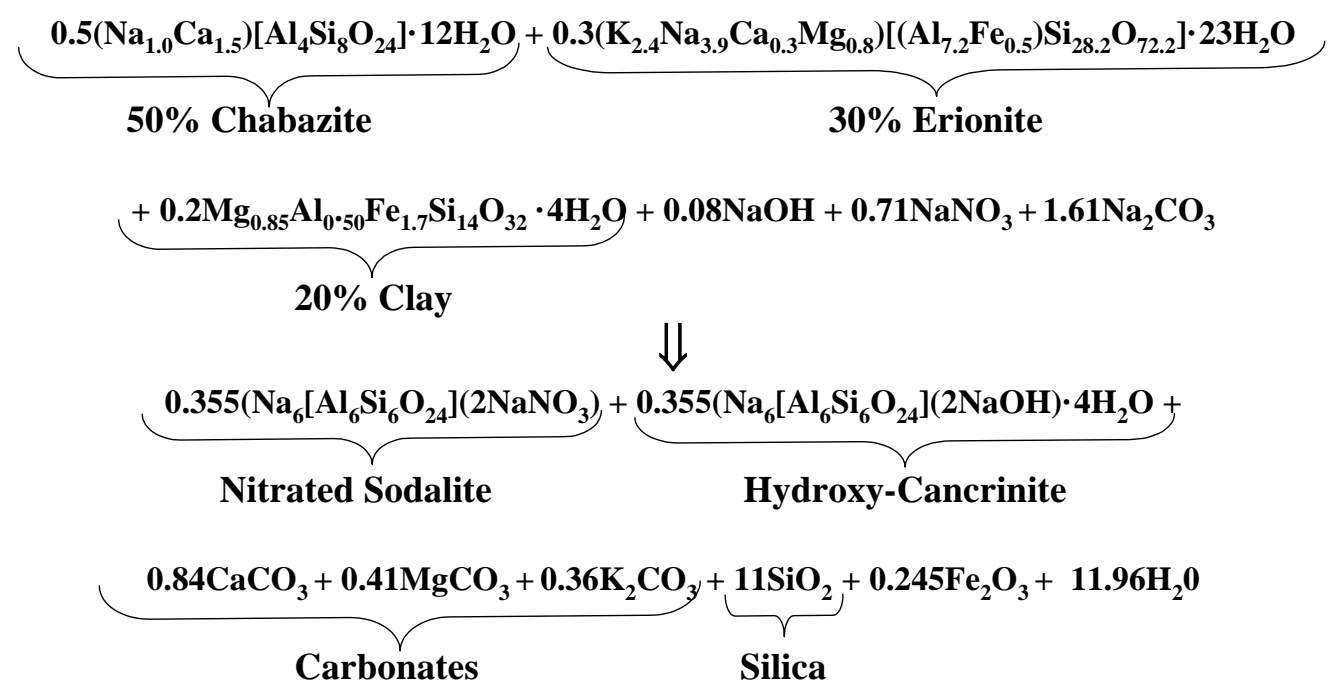

The composition of the converted zeolite is known from the x-ray identification of each phase from Tank 19F as shown in Section 6.1 and Figure 2. The composition of the other conversion products, the carbonates and silica, are known from the comparison of the washed and unwashed simulated samples of IE-95 subjected to $5 \mathrm{M}$ and $10 \mathrm{M} \mathrm{NaOH}$ (Section 6.2 and Table X). Based on the known starting materials and the known reaction products the equation for IE-95 conversion to nitrated sodalite and hydroxycancrinite, carbonates, and silica is as shown above assuming a 50:50 mixture of the nitrated sodalite and hydroxy-canrinite in the Tank 19F mound material. This means that for every mole of IE-95 converted, 11 moles of $\mathrm{SiO}_{2}$ are liberated. From the microscopic examination of the converted zeolite (Figure 9) and the lack of any x-ray diffraction reflections for $\mathrm{SiO}_{2}$ in the Tank 19F sample (Figure 2) this $\mathrm{SiO}_{2}$ may be amorphous even though the $\mathrm{x}$-ray diffraction spectra of the simulants (Table $\mathrm{X}$ ) indicate that it is partially crystalline. All of the Decalso is considered to be amorphous based on the experiments described in Section 8.0 and shown in Figure 11.

Whether the $\mathrm{SiO}_{2}$ liberated upon conversion of IE-95 to sodalite and hydroxy-cancrinite is amorphous or crystalline, it is still a component of the Tank 19F mound, e.g. it is likely that not all of the Si analyzed in the Tank 19F mound is sodalite/cancrinite but some is free $\mathrm{SiO}_{2}$. Free $\mathrm{SiO}_{2}$ may become mobile when the Tank 19F component in SB3 sludge is washed. The SB3 washwater will have to undergo the newly implemented evaporator feed qualification based on $\mathrm{Si}$ and $\mathrm{Al}$ concentration so that it does not become problematic for the SRS evaporators. ${ }^{29}$ Conversely, the amorphous $\mathrm{SiO}_{2}$ may likely have reacted with excess $\mathrm{NaOH}$ in Tank $19 \mathrm{~F}$ and converted to additional sodalite since $\mathrm{Al}$, as $\mathrm{NaAl}(\mathrm{OH})_{4}$, was also present in excess. 


\subsection{ZEOLITE SILICA CONTENT AND IMPACT ON GLASS PROCESSING IN DWPF}

In order to assess the impact of the additional silica and alumina on potential glass processing in DWPF, it is assumed that the Tank $19 \mathrm{~F}$ mound is 50\% nitrated sodalite and $50 \%$ hydroxy-cancrinite. This also assumes that any $\mathrm{SiO}_{2}$ liberated during the conversion of the IE-95 to sodalite/cancrinite continued to react with $\mathrm{NaAl}(\mathrm{OH})_{4}$ and excess $\mathrm{NaOH}$ in the tank creating more sodalite/cancrinite rather than amorphous silica indicated by the decomposition reactions shown in Section 8.0.

Since the nitrated sodalite and hydroxy-cancrinite have the same number of moles of Si and $\mathrm{Al}$, and both have similar molecular weights, the chemical formula of nitrated cancrinite was used to convert the Si measured in Table I to weight \% zeolite solids in the tank. Use of the selective transfer of Tank 19F solids material after salt deinventory in gallons (see Section 2.2) suggests that $\sim 14,338 \mathrm{kgs}$ of zeolite may have been transferred to from Tank 19F to Tank 18F and ultimately to SB3. However, assuming homogeneous transfer of Tank 19F solids material after salt deinventory suggests that a maximum of $48,120 \mathrm{kgs}$ of zeolite could potentially have been transferred. Since only 54,600 lbs. (24,818 kgs.) of zeolite were discharged to Tank 19F before the 1980's deinventory began (See Section 2.1), it is unlikely that twice that amount (48,120 kgs) of zeolite could have been available for transfer to Tank 18F although the liberated $\mathrm{SiO}_{2}$ from IE-95 conversion could have formed additional sodalite/cancrinite in situ in the waste tank and effectively increased the mass. The only other possibility, based on the Tank 19F heel analyses of d'Entremont and Thomas, ${ }^{4}$ is that the transfers from Tank $19 \mathrm{~F}$ to Tank $18 \mathrm{~F}$ were selective, e.g. salt and sludge solids were preferentially transferred over the zeolite solids. The selective transfer hypothesis suggests that $14,338 \mathrm{kgs}$ of zeolite solids may ultimately become part of SB3. All subsequent calculations of the impact of the mound material will be made using the 14,338 kgs of zeolite that could be transferred to Tank $18 \mathrm{~F}$ and ultimately to SB3.

The contribution of the Tank 18F mound zeolite rich material from Tank 19F has not, here-to-fore, been factored into the glass chemistry analysis for SB3 as documented by Peeler, Bibler, and Edwards. ${ }^{3}$ The impact of the zeolite mound material from Tank $18 \mathrm{~F}$ that may be blended into SB3 was not considered in the previous study by Peeler, et $\mathrm{al}^{3}$ because the amount of zeolite had not been factored into the Waste Characterization System (WCS) composition projections used in that study. Additional frit optimization for SB3 has been performed ${ }^{30}$ but the optimization has also not considered the zeolite fraction of the SB3 sludge batch.

The Peeler, et. al. ${ }^{3}$ blending strategy study covered six scenarios, which provided the initial technical basis for evaluating the impact of individual or multiple waste streams to SB3. These scenarios included:

Case \#1 (Baseline): SB3 (including the Tank 51H heel and sand associated with Tank 7F)

Case \#2 SB3 baseline with only the Pu/Gd addition

Case \#3 SB3 baseline with only the Am/Cm addition 
Case \#4 SB3 baseline with both $\mathrm{Am} / \mathrm{Cm}$ and $\mathrm{Pu} / \mathrm{Gd}$ additions

Case \#5 SB3 (including the Tank 51H heel - excluding Tank 7F sand)

Case \#6 SB3 (including the Tank 51H heel - excluding Tank 7F sand) with both $\mathrm{Am} / \mathrm{Cm}$ and $\mathrm{Pu} / \mathrm{Gd}$ additions

The six blending scenarios are reassessed in this study as an example of the potential impact of the zeolite on SB3. The same frits and scenarios were used to demonstrate, on a one-on-one comparative basis, the calculated compositions and glass properties predicted in the Peeler, et al study ${ }^{3}$ without zeolite to those with zeolite. The average zeolite mound mass from Table I in this study was converted to oxide wt\% and normalized to $100 \%$ in order to convert the composition to a glass forming oxide (calcine) basis. Table XI summarizes the individual sludge compositions from Peeler et $\mathrm{al}^{3}$ and contrasts them to the compositions including the zeolite mound contribution (in oxide wt\%) and masses (in kgs on an oxide basis). These compositions are used to evaluate the glass properties of SB3 with the average amount of zeolite. This assessment assumes that the individual waste streams or sludges (Table XI) are "compositional centroids" representing, on average, a composition expected to be blended into SB3. It should also be noted that the nominal compositions do not account for compositional sludge variation.

Table XII summarizes the nominal compositions of the six blending scenarios from the Peeler et al study ${ }^{3}$ and compares them to the nominal compositions calculated assuming the presence of the zeolite mound may account for up to $3.8 \mathrm{wt} \%$ of the blend in each case. The blended sludge compositions given in Table XII are weighted averages based on the oxide wt\%'s and total masses either reported or calculated (Table XI). The data shaded in Table XII clearly indicates that the amount of silica increases by $\sim 1 \mathrm{wt} \%$, the amount of alumina by $\sim 0.6 \mathrm{wt} \%$, and the amount of sodium by $\sim 0.75 \mathrm{wt} \%$ in the SB3 calcines for each case when the contribution from the zeolite mound in Tank 18F is added. Conversely, the sludge components such as $\mathrm{Fe}_{2} \mathrm{O}_{3}, \mathrm{MnO}, \mathrm{U}_{3} \mathrm{O}_{8}$, and $\mathrm{NiO}$ are "diluted" by the additional alkali, silica, and alumina of the zeolite mound mass (see Table XII).

The composition of the blending calculations assumes that individual streams will be evenly distributed or uniformly blended resulting in a "constant" feed to the melter (once frit additions are made). The blending calculations in Table XII are used in conjunction with the DWPF property predictions generated by glass property models. ${ }^{31,32}$ These glass property models are the basis of the DWPF Product Composition Control System (PCCS), which is used to determine the acceptability of each batch of DWPF melter feed.

The PCCS system imposes several constraints on the composition of the feed to define acceptability. These constraints relate process or product properties to composition via prediction models. A feed batch is deemed acceptable if its sample-composition measurements lead to acceptable property predictions after accounting for modeling, measurement, and/or analytic uncertainties. ${ }^{33}$ 
WSRC-TR-2002-00288, Rev. 0

Table XI. Nominal Individual Sludge Compositions (in wt\%, calcine oxide basis)

\begin{tabular}{|c|c|c|c|c|c|}
\hline Oxide & SB3 & $\begin{array}{c}\text { Tank 7F } \\
\text { Sand }\end{array}$ & Pu/Gd & $\mathrm{Am} / \mathrm{Cm}$ & $\begin{array}{c}\text { T19F/T18F } \\
\text { Zeolite }\end{array}$ \\
\hline $\mathrm{Ag}_{2} \mathrm{O}$ & 6.897E-04 & 0.000 & 0.000 & $1.074 \mathrm{E}-03$ & 0.000 \\
\hline $\mathrm{Al}_{2} \mathrm{O}_{3}$ & 18.528 & 0.000 & 0.000 & 1.040 & 35.204 \\
\hline $\mathrm{AmO}_{2}$ & $1.465 \mathrm{E}-03$ & 0.000 & 0.000 & 0.275 & 0.000 \\
\hline $\mathrm{B}_{2} \mathrm{O}_{3}$ & 0.000 & 0.000 & 0.000 & 0.000 & 0.065 \\
\hline $\mathrm{BaO}$ & 0.256 & 0.000 & 0.000 & 0.000 & 0.135 \\
\hline $\mathrm{CaO}$ & 3.686 & 0.000 & 0.000 & 0.000 & 1.650 \\
\hline $\mathrm{CdO}$ & 0.000 & 0.000 & 0.000 & 0.001 & 0.014 \\
\hline $\mathrm{Ce}_{2} \mathrm{O}_{3}$ & 0.357 & 0.000 & 0.000 & 0.598 & 0.487 \\
\hline $\mathrm{Cm}_{2} \mathrm{O}_{3}$ & $1.011 \mathrm{E}-08$ & 0.000 & 0.000 & 0.063 & 0 \\
\hline $\mathrm{Cr}_{2} \mathrm{O}_{3}$ & 0.379 & 0.000 & 0.000 & 0.404 & 0.067 \\
\hline $\mathrm{Cs}_{2} \mathrm{O}$ & 0.000 & 0.000 & 0.000 & 0.000 & 0.000 \\
\hline $\mathrm{CuO}$ & 0.203 & 0.000 & 0.000 & 0.000 & 0.010 \\
\hline $\mathrm{Eu}_{2} \mathrm{O}_{3}$ & 0.000 & 0.000 & 0.000 & 0.000 & 0.000 \\
\hline $\mathrm{Fe}_{2} \mathrm{O}_{3}$ & 41.200 & 0.000 & 0.000 & 4.020 & 4.120 \\
\hline $\mathrm{Gd}_{2} \mathrm{O}_{3}$ & 0.002 & 0.000 & 60.398 & 0.159 & 0.000 \\
\hline $\mathrm{K}_{2} \mathrm{O}$ & 0.441 & 0.000 & 0.000 & 0.000 & 0.018 \\
\hline $\mathrm{La}_{2} \mathrm{O}_{3}$ & 0.206 & 0.000 & 0.000 & 0.427 & 0.028 \\
\hline $\mathrm{Li}_{2} \mathrm{O}$ & 0.000 & 0.000 & 0.000 & 0.284 & 0.014 \\
\hline $\mathrm{MgO}$ & 0.193 & 0.000 & 0.000 & 0.007 & 0.556 \\
\hline $\mathrm{MnO}$ & 7.348 & 0.000 & 0.000 & 0.143 & 0.237 \\
\hline $\mathrm{MoO}_{3}$ & 0.000 & 0.000 & 0.000 & 0.021 & 0.016 \\
\hline $\mathrm{Na}_{2} \mathrm{O}$ & 10.886 & 0.000 & 0.000 & 0.000 & 29.813 \\
\hline $\mathrm{Nd}_{2} \mathrm{O}_{3}$ & 0.685 & 0.000 & 0.000 & 1.234 & 0.000 \\
\hline $\mathrm{NiO}$ & 1.647 & 0.000 & 0.000 & 0.237 & 0.022 \\
\hline $\mathrm{P}_{2} \mathrm{O}_{5}$ & 0.000 & 0.000 & 0.000 & 0.000 & 0.000 \\
\hline $\mathrm{PbO}$ & 0.307 & 0.000 & 0.000 & 0.226 & 0.062 \\
\hline $\mathrm{PdO}$ & 3.757E-02 & 0.000 & 0.000 & 0.002 & 0.000 \\
\hline $\mathrm{Pr}_{2} \mathrm{O}_{3}$ & 0.188 & 0.000 & 0.000 & 0.301 & 0.000 \\
\hline $\mathrm{PuO}_{2}$ & 0.021 & 0.000 & 39.602 & 0.045 & 0.000 \\
\hline $\mathrm{RuO}_{2}$ & 0.284 & 0.000 & 0.000 & 0.043 & 0.000 \\
\hline $\mathrm{RhO}_{2}$ & 0.080 & 0.000 & 0.000 & 0.001 & 0.000 \\
\hline $\mathrm{SiO}_{2}$ & 2.145 & 100.000 & 0.000 & 0.817 & 27.270 \\
\hline $\mathrm{Sm}_{2} \mathrm{O}_{3}$ & 0.101 & 0.000 & 0.000 & 0.121 & 0.000 \\
\hline $\mathrm{SnO}_{2}$ & 0.000 & 0.000 & 0.000 & 0.000 & 0.034 \\
\hline $\mathrm{SrO}$ & 0.000 & 0.000 & 0.000 & 0.000 & 0.032 \\
\hline $\mathrm{ThO}_{2}$ & 0.147 & 0.000 & 0.000 & 0.000 & 0.000 \\
\hline $\mathrm{TiO}_{2}$ & 0.000 & 0.000 & 0.000 & 0.010 & 0.123 \\
\hline $\mathrm{U}_{3} \mathrm{O}_{8}$ & 9.486 & 0.000 & 0.000 & 89.430 & 0.000 \\
\hline $\mathrm{ZnO}$ & 0.421 & 0.000 & 0.000 & 0.017 & 0.012 \\
\hline $\mathrm{ZrO}_{2}$ & 0.761 & 0.000 & 0.000 & 0.026 & 0.000 \\
\hline Total & 100.00 & 100.00 & 100.00 & 100.00 & 100.00 \\
\hline Mass (in kg) & 358236.7 & 4550 & 286.35 & 3796.20 & 14,338 \\
\hline
\end{tabular}


Table XII Nominal Sludge Calcine Compositions (Wt\%) for Various Blending Scenarios With and Without the Tank 19F/Tank 18F Zeolite Contribution

\begin{tabular}{|c|c|c|c|c|c|c|}
\hline & $\begin{array}{c}\text { Case \#1 } \\
\text { (baseline) }\end{array}$ & $\begin{array}{c}\text { Case \#1 } \\
\text { (baseline) }\end{array}$ & Case \#2 & \begin{tabular}{|c||} 
Case \#2 \\
With Zeolite
\end{tabular} & Case \#3 & $\begin{array}{c}\text { Case \#3 } \\
\text { With Zeolite }\end{array}$ \\
\hline Oxide & $\begin{array}{c}\text { SB3 } \\
\text { (including } \\
\text { Tank 51H } \\
\text { heel) with } \\
\text { Tank 7F } \\
\text { sand }\end{array}$ & $\begin{array}{c}\text { SB3 } \\
\text { (including } \\
\text { Tank 51H } \\
\text { heel) with } \\
\text { Tank 7F } \\
\text { sand and } \\
\text { Zeolite }\end{array}$ & $\begin{array}{c}\text { SB3 baseline } \\
\text { with } \mathrm{Pu} / \mathrm{Gd}\end{array}$ & $\begin{array}{c}\text { SB3 baseline } \\
\text { with } \mathrm{Pu} / \mathrm{Gd} \\
\text { and } \mathrm{Zeolite}\end{array}$ & $\begin{array}{l}\text { SB3 baseline } \\
\text { with } \mathrm{Am} / \mathrm{Cm}\end{array}$ & $\begin{array}{l}\text { SB3 baseline } \\
\text { with Am/Cm } \\
\text { and Zeolite }\end{array}$ \\
\hline $\mathrm{Ag}$ & 6.81E-04 & $6.551 \mathrm{E}-04$ & $6.80 \mathrm{E}-04$ & $6.546 \mathrm{E}-04$ & 6.843E-04 & 6.585E-04 \\
\hline $\mathrm{Al}_{2} \mathrm{O}_{3}$ & 18.295 & 18.938 & 18.281 & 18.924 & 18.116 & 18.760 \\
\hline $\mathrm{AmO}_{2}$ & $1.45 \mathrm{E}-03$ & $1.392 \mathrm{E}-03$ & $1.446 \mathrm{E}-03$ & $1.391 \mathrm{E}-03$ & $4.280 \mathrm{E}-03$ & $4.119 \mathrm{E}-03$ \\
\hline $\mathrm{B}_{2} \mathrm{O}_{3}$ & 0.000 & 0.002 & 0.000 & 0.002 & 0.000 & 0.002 \\
\hline $\mathrm{BaO}$ & 0.253 & 0.249 & 0.253 & 0.248 & 0.250 & 0.246 \\
\hline $\mathrm{CaO}$ & 3.640 & 3.564 & 3.637 & 3.562 & 3.602 & 3.529 \\
\hline $\mathrm{CdO}$ & $0.00 \mathrm{E}+00$ & 0.001 & $0.00 \mathrm{E}+00$ & $5.318 \mathrm{E}-04$ & $1.183 \mathrm{E}-05$ & 5.383E-04 \\
\hline $\mathrm{Ce}_{2} \mathrm{O}_{3}$ & 0.353 & 0.358 & 0.353 & 0.358 & 0.355 & 0.360 \\
\hline $\mathrm{Cm}_{2} \mathrm{O}_{3}$ & 9.98E-09 & 9.599E-09 & 9.97E-09 & 9.592E-09 & $6.475 \mathrm{E}-04$ & $6.231 \mathrm{E}-04$ \\
\hline $\mathrm{Cr}_{2} \mathrm{O}_{3}$ & 0.374 & 0.363 & 0.374 & 0.362 & 0.375 & 0.363 \\
\hline $\mathrm{Cs}_{2} \mathrm{O}$ & 0.000 & 0.000 & 0.000 & 0.000 & 0.000 & 0.000 \\
\hline $\mathrm{CuO}$ & 0.200 & 0.193 & 0.200 & 0.193 & 0.198 & 0.191 \\
\hline $\mathrm{Eu}_{2} \mathrm{O}_{3}$ & 4.69E-03 & $4.508 \mathrm{E}-03$ & 4.68E-03 & 4.504E-03 & 4.684E-03 & 4.507E-03 \\
\hline $\mathrm{Fe}_{2} \mathrm{O}_{3}$ & 40.681 & 39.292 & 40.649 & 39.262 & 40.301 & 38.940 \\
\hline $\mathrm{Gd}_{2} \mathrm{O}_{3}$ & 0.002 & 0.002 & 0.050 & 0.048 & 0.004 & 0.003 \\
\hline $\mathrm{K}_{2} \mathrm{O}$ & 0.435 & 0.420 & 0.435 & 0.419 & 0.431 & 0.415 \\
\hline $\mathrm{La}_{2} \mathrm{O}_{3}$ & 0.203 & 0.197 & 0.203 & 0.197 & 0.206 & 0.199 \\
\hline $\mathrm{Li}_{2} \mathrm{O}$ & 0.000 & 0.001 & 0.000 & 0.001 & 0.003 & 0.003 \\
\hline $\mathrm{MgO}$ & 0.191 & 0.205 & 0.191 & 0.204 & 0.189 & 0.203 \\
\hline $\mathrm{MnO}$ & 7.256 & 6.989 & 7.250 & 6.984 & 7.182 & 6.921 \\
\hline $\mathrm{MoO}_{3}$ & 0.000 & 0.001 & 0.000 & 0.001 & 0.000 & 0.001 \\
\hline $\mathrm{Na}_{2} \mathrm{O}$ & 10.749 & 11.474 & 10.740 & 11.465 & 10.637 & 11.359 \\
\hline $\mathrm{Nb}_{2} \mathrm{O}_{3}$ & 0.000 & 0.000 & 0.000 & 0.000 & 0.000 & 0.000 \\
\hline $\mathrm{Nd}_{2} \mathrm{O}_{3}$ & 0.677 & 0.652 & 0.676 & 0.651 & 0.682 & 0.658 \\
\hline $\mathrm{NiO}$ & 1.627 & 1.565 & 1.625 & 1.564 & 1.612 & 1.552 \\
\hline $\mathrm{P}_{2} \mathrm{O}_{5}$ & 0.000 & 0.002 & 0.000 & 0.002 & 0.000 & 0.002 \\
\hline $\mathrm{PbO}$ & 0.303 & 0.292 & 0.303 & 0.292 & 0.303 & 0.291 \\
\hline $\mathrm{Pd}$ & $3.71 \mathrm{E}-02$ & $3.60 \mathrm{E}-02$ & $3.71 \mathrm{E}-02$ & $3.566 \mathrm{E}-02$ & $3.674 \mathrm{E}-02$ & $3.535 \mathrm{E}-02$ \\
\hline $\mathrm{Pr}_{2} \mathrm{O}_{3}$ & 0.185 & 0.178 & 0.185 & 0.178 & 0.187 & 0.180 \\
\hline $\mathrm{PuO}_{2}$ & 0.021 & 0.020 & 0.052 & 0.050 & 0.021 & 0.020 \\
\hline $\mathrm{RuO}_{2}$ & 0.281 & 0.270 & 0.280 & 0.270 & 0.278 & 0.268 \\
\hline $\mathrm{Rh}$ & 7.88E-02 & $7.60 \mathrm{E}-02$ & 7.87E-02 & $7.571 \mathrm{E}-02$ & 7.796E-02 & $7.502 \mathrm{E}-02$ \\
\hline $\mathrm{SiO}_{2}$ & 3.373 & 4.281 & 3.370 & 4.278 & 3.346 & 4.247 \\
\hline $\mathrm{Sm}_{2} \mathrm{O}_{3}$ & 0.100 & 0.096 & 0.100 & 0.096 & 0.100 & 0.097 \\
\hline $\mathrm{SnO}_{2}$ & 0.000 & 0.001 & 0.000 & 0.001 & 0.000 & 0.001 \\
\hline $\mathrm{SrO}$ & 0.000 & 0.001 & 0.000 & 0.001 & 0.000 & 0.001 \\
\hline $\mathrm{ThO}_{2}$ & 0.145 & 0.139 & 0.145 & 0.139 & 0.143 & 0.138 \\
\hline $\mathrm{TiO}_{2}$ & 0.000 & 0.005 & 0.000 & 0.005 & 0.000 & 0.005 \\
\hline $\mathrm{U}_{3} \mathrm{O}_{8}$ & 9.367 & 9.011 & 9.360 & 9.004 & 10.196 & 9.812 \\
\hline $\mathrm{Y}_{2} \mathrm{O}_{3}$ & 0.000 & 0.000 & 0.000 & 0.000 & 0.000 & 0.000 \\
\hline $\mathrm{ZnO}$ & 0.416 & 0.400 & 0.415 & 0.400 & 0.412 & 0.396 \\
\hline $\mathrm{ZrO}_{2}$ & 0.751 & 0.723 & 0.751 & 0.722 & 0.744 & 0.716 \\
\hline Total & 100.000 & 100.00 & 100.000 & 100.000 & 100.000 & 100.000 \\
\hline Mass (in kg) & 362,804 & 377,142 & 363,090 & 377,428 & 366,600 & 380,937 \\
\hline
\end{tabular}


WSRC-TR-2002-00288, Rev. 0

Table XII. Nominal Sludge Calcine Compositions (Wt\%) for Various Blending Scenarios With and Without the Tank 19F/Tank 18F Zeolite Contribution (Cont’d)

\begin{tabular}{|c|c|c|c|c|c|c|}
\hline & Case \#4 & \begin{tabular}{|c|} 
Case \#4 \\
With Zeolite
\end{tabular} & Case \#5 & \begin{tabular}{c|c} 
Case \#5 \\
With Zeolite \\
\end{tabular} & \begin{tabular}{|c|} 
Case \#6 \\
With Zeolite \\
\end{tabular} & \begin{tabular}{|c|} 
Case \#6 \\
With Zeolite \\
\end{tabular} \\
\hline Oxide & $\begin{array}{c}\text { SB3 baseline } \\
\text { with } \mathrm{Pu} / \mathrm{Gd} \\
\text { and } \mathrm{Am} / \mathrm{Cm}\end{array}$ & $\begin{array}{c}\text { SB3 baseline } \\
\text { with } \mathrm{Pu} / \mathrm{Gd} \\
\text { and } \mathrm{Am} / \mathrm{Cm} \\
\text { and } \mathrm{Zeolite}\end{array}$ & $\begin{array}{c}\text { SB3 with } \\
\text { Tank 51H } \\
\text { Heel and } \\
\text { without } \\
\text { Sand }\end{array}$ & $\begin{array}{c}\text { SB3 with } \\
\text { Tank 51H } \\
\text { Heel and } \\
\text { without } \\
\text { Sand and } \\
\text { with Zeolite }\end{array}$ & \begin{tabular}{||c|} 
SB3 without \\
Tank $51 \mathrm{H}$ \\
Heel and \\
without \\
sand, $\mathrm{Pu} / \mathrm{Gd}$, \\
and $\mathrm{Am} / \mathrm{Cm}$
\end{tabular} & $\begin{array}{c}\text { SB3 } \\
\text { withoutTank } \\
51 \mathrm{H} \text { Heel } \\
\text { and without } \\
\text { sand, } \mathrm{Pu} / \mathrm{Gd} \text {, } \\
\text { and } \mathrm{Am} / \mathrm{Cm} \\
\text { and } \mathrm{Zeolite}\end{array}$ \\
\hline $\mathrm{Ag}$ & $6.838 \mathrm{E}-04$ & $6.581 \mathrm{E}-04$ & $6.896 \mathrm{E}-04$ & 6.631E-04 & $6.924 \mathrm{E}-04$ & 6.660E-04 \\
\hline $\mathrm{Al}_{2} \mathrm{O}_{3}$ & 18.102 & 18.746 & 18.528 & 19.169 & 18.330 & 18.972 \\
\hline $\mathrm{AmO}_{2}$ & $4.277 \mathrm{E}-03$ & $4.116 \mathrm{E}-03$ & $1.465 \mathrm{E}-03$ & $1.409 \mathrm{E}-03$ & 4.331E-03 & $4.166 \mathrm{E}-03$ \\
\hline $\mathrm{B}_{2} \mathrm{O}_{3}$ & 0.000 & 0.002 & 0.000 & 0.003 & 0.000 & 0.002 \\
\hline $\mathrm{BaO}$ & 0.250 & 0.246 & 0.256 & 0.252 & 0.253 & 0.249 \\
\hline $\mathrm{CaO}$ & 3.600 & 3.526 & 3.686 & 3.608 & 3.645 & 3.569 \\
\hline $\mathrm{CdO}$ & $1.182 \mathrm{E}-05$ & $5.379 \mathrm{E}-04$ & $0.000 \mathrm{E}+00$ & $5.388 \mathrm{E}-04$ & 1.196E-05 & $5.444 \mathrm{E}-04$ \\
\hline $\mathrm{Ce}_{2} \mathrm{O}_{3}$ & 0.355 & 0.360 & 0.357 & 0.362 & 0.360 & 0.364 \\
\hline $\mathrm{Cm}_{2} \mathrm{O}_{3}$ & $6.470 \mathrm{E}-04$ & $6.227 \mathrm{E}-04$ & $1.010 \mathrm{E}-08$ & 9.716E-09 & $6.551 \mathrm{E}-04$ & 6.302E-04 \\
\hline $\mathrm{Cr}_{2} \mathrm{O}_{3}$ & 0.374 & 0.363 & 0.379 & 0.367 & 0.379 & 0.367 \\
\hline $\mathrm{Cs}_{2} \mathrm{O}$ & 0.000 & 0.000 & 0.000 & 0.000 & 0.000 & 0.000 \\
\hline $\mathrm{CuO}$ & 0.198 & 0.191 & 0.203 & 0.196 & 0.201 & 0.193 \\
\hline $\mathrm{Eu}_{2} \mathrm{O}_{3}$ & $4.680 \mathrm{E}-03$ & $4.504 \mathrm{E}-03$ & 4.745E-03 & $4.563 \mathrm{E}-03$ & 4.739E-03 & $4.558 \mathrm{E}-03$ \\
\hline $\mathrm{Fe}_{2} \mathrm{O}_{3}$ & 40.270 & 38.911 & 41.198 & 39.771 & 40.776 & 39.381 \\
\hline $\mathrm{Gd}_{2} \mathrm{O}_{3}$ & 0.051 & 0.049 & 0.002 & 0.002 & 0.051 & 0.049 \\
\hline $\mathrm{K}_{2} \mathrm{O}$ & 0.431 & 0.415 & 0.441 & 0.425 & 0.436 & 0.420 \\
\hline $\mathrm{La}_{2} \mathrm{O}_{3}$ & 0.206 & 0.199 & 0.206 & 0.199 & 0.208 & 0.201 \\
\hline $\mathrm{Li}_{2} \mathrm{O}$ & 0.003 & 0.003 & 0.000 & 0.001 & 0.003 & 0.003 \\
\hline $\mathrm{MgO}$ & 0.189 & 0.202 & 0.193 & 0.207 & 0.191 & 0.205 \\
\hline $\mathrm{MnO}$ & 7.177 & 6.916 & 7.348 & 7.074 & 7.267 & 6.999 \\
\hline $\mathrm{MoO}_{3}$ & 0.000 & 0.001 & 0.000 & 0.001 & 0.000 & 0.001 \\
\hline $\mathrm{Na}_{2} \mathrm{O}$ & 10.629 & 11.351 & 10.885 & 11.614 & 10.763 & 11.488 \\
\hline $\mathrm{Nb}_{2} \mathrm{O}_{3}$ & 0.000 & 0.000 & 0.000 & 0.000 & 0.000 & 0.000 \\
\hline $\mathrm{Nd}_{2} \mathrm{O}_{3}$ & 0.682 & 0.657 & 0.685 & 0.660 & 0.691 & 0.665 \\
\hline $\mathrm{NiO}$ & 1.611 & 1.551 & 1.647 & 1.584 & 1.631 & 1.569 \\
\hline $\mathrm{P}_{2} \mathrm{O}_{5}$ & 0.000 & 0.002 & 0.000 & 0.002 & 0.000 & 0.002 \\
\hline $\mathrm{PbO}$ & 0.302 & 0.291 & 0.307 & 0.295 & 0.306 & 0.295 \\
\hline $\mathrm{Pd}$ & $3.671 \mathrm{E}-02$ & 3.533E-02 & 3.757E-02 & 3.612E-02 & 3.717E-02 & 3.575E-02 \\
\hline $\mathrm{Pr}_{2} \mathrm{O}_{3}$ & 0.186 & 0.179 & 0.188 & 0.180 & 0.189 & 0.182 \\
\hline $\mathrm{PuO}_{2}$ & 0.052 & 0.050 & 0.021 & 0.020 & 0.053 & 0.051 \\
\hline $\mathrm{RuO}_{2}$ & 0.278 & 0.267 & 0.284 & 0.273 & 0.281 & 0.271 \\
\hline $\mathrm{Rh}$ & 7.790E-02 & 7.497E-02 & 7.976E-02 & 7.669E-02 & 7.888E-02 & 7.587E-02 \\
\hline $\mathrm{SiO}_{2}$ & 3.343 & 4.243 & 2.145 & 3.112 & 2.130 & 3.087 \\
\hline $\mathrm{Sm}_{2} \mathrm{O}_{3}$ & 0.100 & 0.096 & 0.101 & 0.097 & 0.101 & 0.098 \\
\hline $\mathrm{SnO}_{2}$ & 0.000 & 0.001 & 0.000 & 0.001 & 0.000 & 0.001 \\
\hline $\mathrm{SrO}$ & 0.000 & 0.001 & 0.000 & 0.001 & 0.000 & 0.001 \\
\hline $\mathrm{ThO}_{2}$ & 0.143 & 0.138 & 0.147 & 0.141 & 0.145 & 0.139 \\
\hline $\mathrm{TiO}_{2}$ & 0.000 & 0.005 & 0.000 & 0.005 & 0.000 & 0.005 \\
\hline $\mathrm{U}_{3} \mathrm{O}_{8}$ & 10.188 & 9.805 & 9.486 & 9.121 & 10.316 & 9.923 \\
\hline $\mathrm{Y}_{2} \mathrm{O}_{3}$ & 0.000 & 0.000 & 0.000 & 0.000 & 0.000 & 0.000 \\
\hline $\mathrm{ZnO}$ & 0.411 & 0.396 & 0.421 & 0.405 & 0.416 & 0.401 \\
\hline $\mathrm{ZrO}_{2}$ & 0.743 & 0.715 & 0.761 & 0.732 & 0.752 & 0.724 \\
\hline Total & 100.000 & 100.00 & 100.000 & 100.00 & 100.00 & 100.000 \\
\hline Mass (in kg) & 366,886 & 381,224 & 358,254 & 372,591 & 362,336 & 376,674 \\
\hline
\end{tabular}


Calculations were performed on the data in Table XII (the nominal sludge compositions converted to a calcine basis) to simulate blending of the calcined feed with various glass forming frits (Frit 200, 165 and 320) for a one-to-one comparison with the Peeler, et. al. ${ }^{3}$ study. These blended calcined sludge/frit mixtures were used as the basis for the glass impact assessment of the Tank 19F mound material. These three different frits were assessed as examples.

The properties assessed in this study included durability (Product Consisteny Test (PCT) (ASTM 1997) response in terms of $\left.\Delta \mathrm{G}_{\mathrm{P}}\right),{ }^{34}$ viscosity $(\eta),{ }^{31}$ liquidus temperature $\left(\mathrm{T}_{\mathrm{L}}\right.$ using both the previous ${ }^{31}$ and newly implemented ${ }^{32}$ models), and $\mathrm{Al}_{2} \mathrm{O}_{3}$ and alkali concentrations. To establish or project operational windows for the various blending scenarios, predicted properties must be assessed relative to established acceptance criteria. Acceptable predicted properties for this assessment are based on satisfying their respective Property Acceptable Region (PAR) limit values (see Table XIII) - not the more restrictive Measurement Acceptability Region (MAR) limits. It should be noted that the PAR limit set for assessing the new $\mathrm{T}_{\mathrm{L}}$ model was conservatively set at $1010^{\circ} \mathrm{C}$ (consistent with that used by Brown et $\mathrm{al}^{32}$ ). $\S$ It is anticipated that the PAR limits for the new model will not be this restrictive (in terms of limiting the projected compositional operating window). Therefore, in the assessment discussions that follow, when the new $\mathrm{T}_{\mathrm{L}}$ model imposes or limits the projected operational window, one must remember the use of this conservatively set PAR limit. More specifically, failing this constraint (as currently defined) does not necessarily mean that it would be an unacceptable glass given the conservative $1010^{\circ} \mathrm{C}$ PAR limit.

Table XIII PAR Limits for Various Properties

\begin{tabular}{|c|c|}
\hline Property & PAR Limit \\
\hline $\mathrm{T}_{\mathrm{L}}$ (existing) & $<1024.95^{\circ} \mathrm{C}$ \\
\hline $\mathrm{T}_{\mathrm{L}}$ (new) & $<1010^{\circ} \mathrm{C}$ \\
\hline$\Delta \mathrm{G}_{\mathrm{P}}$ (durability) & $>-12.7178$ \\
\hline$\eta_{1150^{\circ} \mathrm{C}}$ (melt viscosity) & $21.5-105.4$ Poise \\
\hline $\mathrm{Al}_{2} \mathrm{O}_{3}$ & $\geq 3.0 \mathrm{wt} \%$ (in glass) \\
\hline$\Sigma$ alkali & $<19.3 \mathrm{wt} \%$ (in glass) \\
\hline
\end{tabular}

The $\Delta \mathrm{G}_{\mathrm{P}}$ calculations used in this study represent the glass durability / composition ( $\left.\Delta \mathrm{G}_{\mathrm{P}}\right)$ model currently implemented in PCCS and used by DWPF. That model utilizes specific

$\S \quad$ Information regarding the new $T_{L}$ model was used to assist in the evaluation of glass compositions in this study. The PAR for this relationship is composition-dependent but has been conservatively set at $1010^{\circ} \mathrm{C}$. The full impact of this new $T_{\mathrm{L}}$ model on the DWPF operating window is still being assessed, so no attempt was made in this study to incorporate the actual PAR determinations for the new model. 
$\Delta \mathrm{G}_{\mathrm{P}, \mathrm{i}}$ values reported by Jantzen et $\mathrm{al}^{34}$ (typically for elements whose oxides concentrations are present at $>0.5 \mathrm{wt} \%$ in glass) to predict the $\Delta \mathrm{G}_{\mathrm{p}}$ for a specific SME composition which, prior to processing, is then compared to three SME acceptability criteria, the most restrictive of which is -12.7178 . The use of a modified $\Delta \mathrm{G}_{\mathrm{p}}$ as derived by Peeler et al $^{3}$ by substituting $\Delta \mathrm{G}_{\mathrm{i}}$ 's for chemically similar oxide components was not considered in this study. The modified $\Delta \mathrm{G}_{\mathrm{P}}$ calculation was not used because Peeler et $\mathrm{al}^{3}$ had shown that the impacts of considering these minor oxides were minimal to the overall prediction of glass durability in SB3.

A summary of the predicted properties of the six different sludge batch scenarios blended with each of the three frits being used as examples is shown in Table XIV. The predicted properties demonstrate the following:

- the maximum waste loading with the zeolite mound material present is consistently higher than the maximum waste loading without the zeolite mound material present

- $\quad$ the maximum waste loadings for SB3 without zeolite was 37-37.5 wt $\%$ with Frit 320 depending on the sludge scenario being considered (see Table XIII)

- $\quad$ the maximum waste loadings for SB3 with zeolite was 0.5-2 wt\% waste loading higher (37.5-39 wt\%) with Frit 320 regardless of the sludge scenario being considered (see Table XIII and Figure 14)

- the maximum waste loading is always limited by the new liquidus temperature $\left(T_{L}\right)$ of the glass for the sludge scenarios examined in this study

- the new $T_{L}$ in turn is driven by the amount of sludge components such as $\mathrm{Fe}_{2} \mathrm{O}_{3}, \mathrm{NiO}$, and $\mathrm{MnO}$ present in the glass which is diluted by the increased $\mathrm{Na}_{2} \mathrm{O}, \mathrm{Al}_{2} \mathrm{O}_{3}$ and $\mathrm{Na}_{2} \mathrm{O}$ present in the zeolite material

- the zeolite (high sodium aluminosilicate) dilutes the sludge components in the glass and lowers the $T_{L}$ allowing for higher waste loadings

- the proposed glasses based on Frits 320, 165, and 200 are all durable regardless of sludge scenario and the presence of zeolite

- the proposed glasses all have acceptable viscosities despite increased $\mathrm{Al}_{2} \mathrm{O}_{3}$ from the zeolite

- $\quad$ the viscosities with Frit 320 and Frit 165 are comparable

- the viscosities with Frit 200 are higher which may negatively impact melt rate 


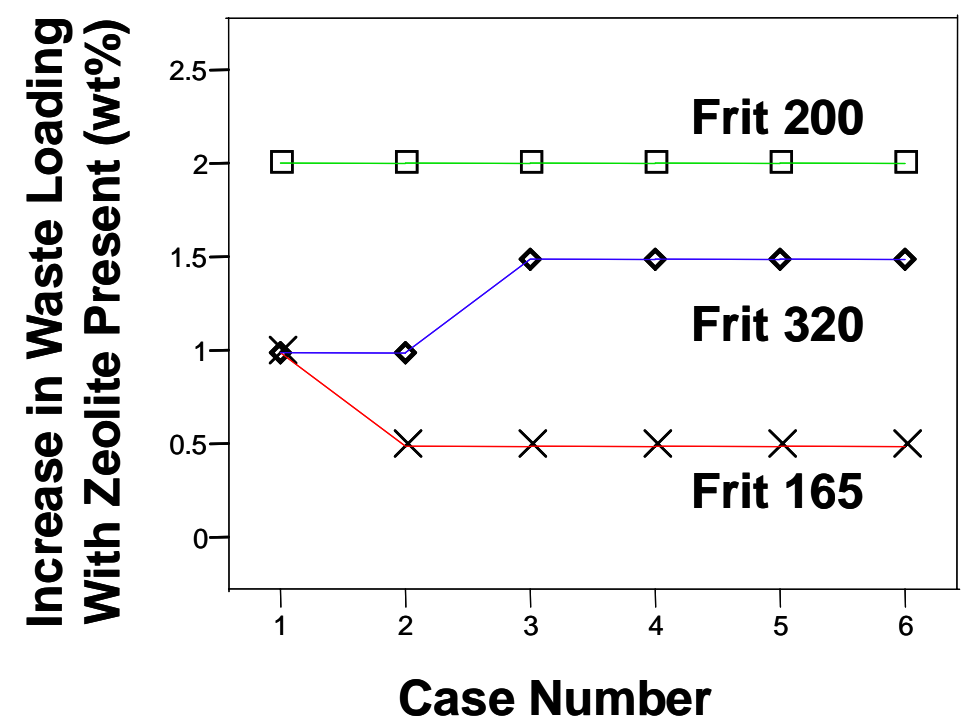

Figure 14. Increases in waste loading that can be achieved with various frits for SB3 due to the presence of zeolite. Data from Table XIII. 
Table XIV. Summary of Predicted Properties at Maximum Allowable Waste Loading (using the new $\mathrm{T}_{\mathrm{L}}$ model and PAR limits).

\begin{tabular}{|c|c|c|c|c|c|c|c|c|c|c|}
\hline & \begin{tabular}{|c|} 
Max \\
WL \\
with \\
Zeolite \\
\end{tabular} & \begin{tabular}{|c|} 
Max \\
WL \\
without \\
Zeolite $^{t}$ \\
\end{tabular} & & & $\mathrm{Al}_{2} \mathbf{O}_{3}$ & $\Sigma$ Alkalis & Viscosity & $\begin{array}{c}\text { PCCS } \\
\Delta G_{p}\end{array}$ & $\begin{array}{l}\text { Old } \\
\mathbf{T}_{\mathrm{L}}\end{array}$ & $\begin{array}{c}\text { New } \\
T_{L}\end{array}$ \\
\hline $\begin{array}{c}\text { Frit-Sludge } \\
\text { Case }\end{array}$ & (wt\%) & $(w t \%)$ & Satisfies PAR & $\begin{array}{l}\text { Violates } \\
\text { PAR }\end{array}$ & $\begin{array}{c}\text { (wt } \\
\text { fraction) }\end{array}$ & $\begin{array}{c}\text { (wt } \\
\text { fraction) }\end{array}$ & (Poise) & $\begin{array}{c}\text { (kcal/m } \\
\text { ol) }\end{array}$ & $\left({ }^{\circ} \mathrm{C}\right)$ & (C) \\
\hline 165-Case 1 & 36.5 & 35.5 & Durable; Visc;New $\mathrm{T}_{\mathrm{L}} ; \mathrm{Al}_{2} \mathrm{O}_{3}$; alkali & Old $\mathrm{T}_{\mathrm{L}}$ & 0.0690 & 0.170 & 35.7 & -9.71 & 1103.4 & 1008.8 \\
\hline 200-Case 1 & 32.5 & 30.5 & Durable; Visc; $\mathrm{T}_{\mathrm{L}} ; \mathrm{New} \mathrm{T}_{\mathrm{L}} ; \mathrm{Al}_{2} \mathrm{O}_{3}$; alkali & Old $\mathrm{T}_{\mathrm{L}}$ & 0.0620 & 0.147 & 73.8 & -8.22 & 1037.9 & 1009.1 \\
\hline 320-Case 1 & 38.5 & 37.5 & Durable; Visc;New $\mathrm{T}_{\mathrm{L}} ; \mathrm{Al}_{2} \mathrm{O}_{3}$; alkali & Old $\mathrm{T}_{\mathrm{L}}$ & 0.0730 & 0.169 & 40.9 & -9.09 & 1114.0 & 1004.9 \\
\hline 165-Case 2 & 36.5 & 36.0 & Durable; Visc;New $\mathrm{T}_{\mathrm{L}} ; \mathrm{Al}_{2} \mathrm{O}_{3}$; alkali & Old $\mathrm{T}_{\mathrm{L}}$ & 0.0690 & 0.170 & 35.8 & -9.71 & 1103.1 & 1008.5 \\
\hline 200-Case 2 & 32.5 & 30.5 & Durable; Visc;New $\mathrm{T}_{\mathrm{L}} ; \mathrm{Al}_{2} \mathrm{O}_{3}$; alkali & Old $\mathrm{T}_{\mathrm{L}}$ & 0.0620 & 0.147 & 73.9 & -8.22 & 1037.7 & 1008.9 \\
\hline 320-Case 2 & 38.5 & 37.5 & Durable; Visc;New $\mathrm{T}_{\mathrm{L}} ; \mathrm{Al}_{2} \mathrm{O}_{3}$; alkali & Old $\mathrm{T}_{\mathrm{L}}$ & 0.0730 & 0.169 & 40.9 & -9.09 & 1113.7 & 1004.7 \\
\hline 165-Case 3 & 36.5 & 36.0 & Durable; Visc;New $\mathrm{T}_{\mathrm{L}} ; \mathrm{Al}_{2} \mathrm{O}_{3}$; alkali & Old $\mathrm{T}_{\mathrm{L}}$ & 0.0680 & 0.170 & 36.0 & -9.71 & 1100.1 & 1006.5 \\
\hline 200-Case 3 & 32.5 & 30.5 & Durable; Visc;New $\mathrm{T}_{\mathrm{L}} ; \mathrm{Al}_{2} \mathrm{O}_{3}$; alkali & Old $\mathrm{T}_{\mathrm{L}}$ & 0.0610 & 0.147 & 74.2 & -8.22 & 1035.4 & 1006.9 \\
\hline 320-Case 3 & 39.0 & 37.5 & Durable; Visc;New $\mathrm{T}_{\mathrm{L}} ; \mathrm{Al}_{2} \mathrm{O}_{3}$; alkali & Old $\mathrm{T}_{\mathrm{L}}$ & 0.0730 & 0.168 & 40.5 & -9.04 & 1118.6 & 1009.1 \\
\hline 165-Case 4 & 36.5 & 36.0 & Durable; Visc;New $\mathrm{T}_{\mathrm{L}} ; \mathrm{Al}_{2} \mathrm{O}_{3}$; alkali & Old $\mathrm{T}_{\mathrm{L}}$ & 0.0680 & 0.170 & 36.5 & -9.71 & 1099.8 & 1006.3 \\
\hline 200-Case 4 & 32.5 & 30.5 & Durable; Visc;New $\mathrm{T}_{\mathrm{L}} ; \mathrm{Al}_{2} \mathrm{O}_{3}$; alkali & Old $\mathrm{T}_{\mathrm{L}}$ & 0.0610 & 0.146 & 74.3 & -8.22 & 1035.2 & 1006.7 \\
\hline 320-Case 4 & 39.0 & 37.5 & Durable; Visc;New $\mathrm{T}_{\mathrm{L}} ; \mathrm{Al}_{2} \mathrm{O}_{3}$; alkali & Old $\mathrm{T}_{\mathrm{L}}$ & 0.0730 & 0.168 & 40.6 & -9.09 & 1118.3 & 1008.9 \\
\hline 165-Case 5 & 36.0 & 35.5 & Durable; Visc;New $\mathrm{T}_{\mathrm{L}} ; \mathrm{Al}_{2} \mathrm{O}_{3}$; alkali & Old $\mathrm{T}_{\mathrm{L}}$ & 0.0690 & 0.171 & 36.0 & -9.80 & 1103.7 & 1006.8 \\
\hline 200-Case 5 & 32.0 & 30.0 & Durable; Visc;New $\mathrm{T}_{\mathrm{L}} ; \mathrm{Al}_{2} \mathrm{O}_{3}$; alkali & Old $\mathrm{T}_{\mathrm{L}}$ & 0.0610 & 0.147 & 72.4 & -8.30 & 1037.2 & 1006.9 \\
\hline 320-Case 5 & 38.5 & 37.0 & Durable; Visc;New $\mathrm{T}_{\mathrm{L}} ; \mathrm{Al}_{2} \mathrm{O}_{3}$; alkali & Old $\mathrm{T}_{\mathrm{L}}$ & 0.0740 & 0.169 & 38.9 & -9.14 & 1122.8 & 1009.5 \\
\hline 165-Case 6 & 36.0 & 35.5 & Durable; Visc;New $\mathrm{T}_{\mathrm{L}} ; \mathrm{Al}_{2} \mathrm{O}_{3}$; alkali & Old $\mathrm{T}_{\mathrm{L}}$ & 0.0680 & 0.171 & 34.9 & -9.80 & 1100.0 & 1004.3 \\
\hline 200-Case 6 & 32.0 & 30.0 & Durable; Visc;New $\mathrm{T}_{\mathrm{L}} ; \mathrm{Al}_{2} \mathrm{O}_{3}$; alkali & Old $\mathrm{T}_{\mathrm{L}}$ & 0.0610 & 0.147 & 72.9 & -8.29 & 1034.5 & 1004.4 \\
\hline 320-Case 6 & 38.5 & 37.0 & Durable; Visc;New $\mathrm{T}_{\mathrm{L}} ; \mathrm{Al}_{2} \mathrm{O}_{3}$; alkali & Old $\mathrm{T}_{\mathrm{L}}$ & 0.0730 & 0.169 & 39.3 & -9.14 & 1118.8 & 1006.9 \\
\hline
\end{tabular}

$\mathrm{t}=$ from Peeler et $\mathrm{al}^{3}$ 


\subsection{CONCLUSIONS}

A maximum of 48,120 kgs of sodium aluminosilicate rich zeolite from the Tank 19F mound may have been transferred to Tank 18F and potentially to SB3 if the transfers of solids from Tank 19F to Tank 18F were homogeneous. However, calculations of the residual zeolite in Tank 19F indicates that only 14,338 kgs of zeolite were transferred indicating that the salt and sludge solids in the mound in Tank $19 \mathrm{~F}$ were transferred to Tank 18F selectively over the zeolite solids. This is in agreement with the fact that only $\sim 24,818$ kgs of zeolite were discharged to Tank 19F over its lifetime of zeolite receipt. This converts to approximately $3.8 \mathrm{wt} \%$ of the proposed SB3 constituents if all of the zeolite material in Tank 18F is blended into SB3.

The two potential impacts of the Tank 19F zeolite mound on DWPF processing relates to (1) the Hydragard ${ }^{\circledR}$ samples taken for determination of the acceptability of a macrobatch of DWPF feed and (2) the achievable waste loading. An additional impact that may affect processing of SB3 and/or the evaporation of SB3 washwater relates to the liberation of $\mathrm{SiO}_{2}$ from the zeolite to the sludge when it aged from chabazite and erionite (IE-95 constituents) to the cancrinite/sodalite phases currently found in the Tank 19F mound.

In terms of the Hydragard ${ }^{\circledR}$ sampling of SB3 feeds for DWPF SME process control:

- the larger zeolite particles found in Tank 19F (average particle size of $500 \mu \mathrm{m}$ ) and subsequently transferred to Tank $18 \mathrm{~F}$ are too large to pass through the sampling valve and may plug the valve unless they are size reduced during subsequent transfers, homogenization, or processing

- the DWPF sampling system may not be capable of obtaining a representative sample of sludge containing zeolite if the particle size is not size reduced during subsequent transfers, homogenization, or processing

- sampling could miss an estimated $60 \%$ of the material causing misbatching of the feeds to the DWPF if the particle size is not size reduced during subsequent transfers, homogenization, or processing

- zeolite must be further degraded (particle size reduced) before Hydragard ${ }^{\circledR}$ sampling can be considered accurate for DWPF process control if the particle size is not size reduced during subsequent transfers, homogenization, or processing

The potential effects of the large size of the zeolite particles found in the Tank 19F solids, as reported in this study, are considered minimal for processing of SB3 in DWPF. This conclusion is based on recent sieve analyses of Tank 51H sludge after receipt from Tank $18 \mathrm{~F}$ which indicate that only $0.04 \mathrm{wt} \%$ particulates over $38 \mu \mathrm{m}$ are present in the sludge. These particulates appear to be coal and not zeolite. The sieve analyses indicate that the zeolite that was transferred may have degraded in size during all the tank homogenization and transfers if the sample that was sieved was representative of the tank contents. Moreover, recent analyses of Tank $18 \mathrm{~F}$ indicate that the heel remaining in 
Tank $18 \mathrm{~F}$ is enriched in silica, ${ }^{1}$ presumably zeolite, indicating that not all the zeolite from Tank $18 \mathrm{~F}$ was transferred to SB3. The zeolite heel in Tank $18 \mathrm{~F}$ will only become problematic for DWPF processing if the contents of Tank 18F ever become feed for subsequent DWPF feed.

The second potential impact on DWPF processing will be the ability to achieve higher waste loadings by $\sim 0.5-2.0 \mathrm{wt} \%$. In order to have a 1:1 correlation of the calculated waste loadings with and without zeolite present, comparisons to earlier calculations were made based on Frits 320, 165, and 200. The predicted glass properties at the property acceptable region (PAR) demonstrates the following:

- $\quad$ the maximum waste loading with the zeolite mound material present is consistently higher than the maximum waste loading without the zeolite mound material present

- $\quad$ the maximum waste loadings for SB3 without zeolite was 37-37.5 wt $\%$ with Frit 320 depending on the sludge scenario being considered

- $\quad$ the maximum waste loadings for SB3 with zeolite was 0.5-2 wt\% waste loading higher (37.5-39 wt\%) with Frit 320 regardless of the sludge scenario being considered

- the maximum waste loading is always limited by the new liquidus temperature $\left(T_{L}\right)$ of the glass for the sludge scenarios examined in this study

- the new $\mathrm{T}_{\mathrm{L}}$ in turn is driven by the amount of sludge components such as $\mathrm{Fe}_{2} \mathrm{O}_{3}, \mathrm{NiO}$, and $\mathrm{MnO}$ present in the glass which is diluted by the increased $\mathrm{Na}_{2} \mathrm{O}, \mathrm{Al}_{2} \mathrm{O}_{3}$, and $\mathrm{Na}_{2} \mathrm{O}$ present in the zeolite material

- $\quad$ the zeolite (high sodium aluminosilicate) dilutes the sludge components in the glass and lowers the $\mathrm{T}_{\mathrm{L}}$ allowing for higher waste loadings

- the proposed glasses based on Frits 320, 165, and 200 are all durable regardless of sludge scenario and the presence of zeolite, this is consistent with new optimized frits developed for SB3

- the proposed glasses all have acceptable viscosities despite increased $\mathrm{Al}_{2} \mathrm{O}_{3}$ from the zeolite

- the viscosities with Frit 320 and Frit 165 are comparable

- $\quad$ the viscosities with Frit 200 are higher which may negatively impact melt rate

- almost all the glasses violate the old $\mathrm{T}_{\mathrm{L}}$ model but all the glasses satisfy the new, more rigorous, $\mathrm{T}_{\mathrm{L}}$ model which has been implemented in DWPF

Another potential impact of the zeolite from Tank 19F in SB3 may affect the processing of SB3 and/or the evaporation of SB3 washwater:

\footnotetext{
1 Jonathan Thomas, personnel communication September 16, 2003.
} 
- during zeolite aging from the IE-95 components chabazite and erionite to the sodalite/cancrinite mineral phases identified in the Tank 19F mound, 11 moles of $\mathrm{SiO}_{2}$ are liberated

- the $\mathrm{SiO}_{2}$ liberated may be amorphous or may have reacted with excess $\mathrm{NaOH}$ in Tank 19F to form more sodalite in which case the conservative $14,338 \mathrm{kgs}$ of zeolite transferred to SB3 may be as high as 48,120 kgs

- the $\mathrm{SiO}_{2}$ liberated may be amorphous and may be entrained in or part of the SB3 sludge

- if the $\mathrm{SiO}_{2}$ liberated during zeolite conversion is amorphous it could become mobile during sludge washing causing the washwater to fail the newly implemented Si feed qualification limit that was implemented to avoid problematic aluminosilicate scale in the SRS evaporators

Other findings in this study that have little to no impact on DWPF processing and/or the evaporators are the following:

- the mineral components of the IE-95 resin, chabazite and erionite, age in HLW tanks at $\sim 40^{\circ} \mathrm{C}$ to sodalite and cancrinite (feldspathoids)

- the identification of natrodavyne as a reaction product of IE-95 is consistent with recent identification of sodalite/cancrinite species since natrodavyne is a carbonate substituted cancrinite

- anion analysis indicated that $\mathrm{NO}_{3}{ }^{-}$is the only anion in the sodalite/cancrinite, e.g. no $\mathrm{NO}_{2}{ }^{-}$was present in the mound material

- mass balance of the cation and anion analysis suggests that on average the Tank $19 \mathrm{~F}$ mound is $\sim 62 \mathrm{wt} \%$ sodalite, $2.2 \mathrm{wt} \% \mathrm{NaNO}_{3}, 36 \mathrm{wt} \% \mathrm{Al}(\mathrm{OH})_{3}$ and $4 \mathrm{wt} \% \mathrm{Fe}(\mathrm{OH})_{3}$

- aging is a dewatering and densification mechanism (Ostwald ripining), the reaction products are denser than the zeolites from which they are derived but more thermodynamically stable

- the cell volumes of the reaction products are $1 / 3$ the cell volumes of the zeolites

- the framework densities of the reaction products are higher than that of the zeolites

- the particle size of the reaction products is about 2/3 of the original IE-95 but the particle size distributions are identical, Gaussian with a low particle size tail indicating that the IE-95 converted in-situ

- densification (aging) is associated with dehydration and loss of $\mathrm{SiO}_{2}$ 
- the measured dehydration of the Tank 19F mound while in contact with aqueous solution is consistent with this mechanism

- the mechanism and reaction products were identified by studying the conversion of IE-95 in $5 \mathrm{M}$ and $10 \mathrm{M} \mathrm{NaOH}$ as a function of time in both the washed and unwashed conditions

- conversion of IE-95 is rapid, 2 days, in 10M NaOH

- conversion of IE-95 in 10M CsOH forms Cs substituted chabazite (the original mineral phase in IE-95 and a Cs aluminosilicate known as pollucite $\left(\mathrm{CsAlSi}_{2} \mathrm{O}_{6}\right)$

- the bulk density of IE-95 is $\sim 0.791 \mathrm{~g} / \mathrm{cc}$ while the mineral density is 2.28 g/cc

- a second ion exchange media, Decalso, was also added to Tank 19F but in smaller amounts than the IE-95

- Decalso was analyzed to be an amorphous sodium aluminosilicate

- Decalso degrades in $10 \mathrm{M} \mathrm{NaOH}$ to an amorphous aluminosilicate gel

\subsection{ACKNOWLEDGEMENTS}

Special thanks are due to Amy Ekechukwu for performing the anion analyses on the Tank 19F mound sample, to Chuck Coleman for performing the weight loss measurements on the Tank 19F samples, and to Don Blankenship for particle size analysis of the Tank 19F samples and the unreacted IE-95 resin. In addition, Alex Cozzi is thanked for performing the density measurements on unreacted IE-95. Dan Lambert is thanked for his many helpful discussions about the impact of the particle size distribution on DWPF Hydragard ${ }^{\circledR}$ sampling. Ed Stevens is thanked for initiating the work and for his patience.

This work was performed under contract No. DE-AC09-96SR18500 with the Department of Energy. 


\subsection{REFERENCES}

1 T.B. Caldwell, D.P. Chew, H.H. Elder, M.J. Mahoney, K.B. Way, W.A. Wilson, F.E. Wise, "Savannah River Site High Level Waste System Plan (HLW), HLW-2002-00025, Rev. 13,”Aiken, South Carolina (March 2002).

2 D.L. Kiser and B.E. Murphree, “Savannah River Laboratory Information Meeting on Zeolite Management,” U.S. DOE Report DPST-79-566, E.I. duPont deNemours \& Co., Aiken, SC (November, 1979).

3 D.K. Peeler, N.E. Bibler, and T.B. Edwards, “An Assessment of the Impacts of Adding Pu/Gd and Am/Cm Waste Streams to Sludge Batch 3 (SB3) on DWPF $\mathrm{H}_{2}$ Generation Rates and Glass Properties," U.S. DOE Report WSRC-TR-2002-00145, Rev. 0, Westinghouse Savannah River Co., Aiken, SC (March 22, 2002).

$4 \quad$ P.D. d'Entremont and J.L. Thomas, “Characterization of Tank 19 Residual Waste,” U.S. DOE Report WSRC-TR-2002-00052, Westinghouse Savannah River Co., Aiken, SC (March, 2002).

5 J.R. Fowler and R.M. Wallace, “CRC Zeolite in SRP Waste,” U.S. DOE Report DPST-80-488, E.I. duPont deNemours \& Co., Aiken, SC (December 2, 1980).

6 A. Rose and E. Rose (Eds.), "The Condensed Chemical Dictionary," $5^{\text {th }}$ Edition, Reinhold Publishing Co., New York, 1200pp. (1956).

7 A.Q. Goslen, “Tank 19 Salt Removal,” U.S. DOE Report DPSP-84-17-7, E.I. duPont deNemours \& Co., Aiken, SC (August, 1986).

8 C. R. Hayes, “Sampling, Analysis and Characterization Plan to Support HLW Tank 19 Closure”, HLW-REG-2000-00033, Rev. 1, August 30, 2001.

9 B. Martin and B. Adkins, “Tank 19 Closure Strategy”, HLW-WRE-200100048, August 16, 2001.

10 J. L. Thomas, “Tank 19 Heel, Supernate, and Possible Unmoved Heel Mounds Volume Calculation,” G-CLC-F-00180, Rev. 1, February 25, 2002.

11 M.S. Hay, “Characterization of Tank 19F Samples in Support of Tank Closure,” U.S. DOE Report WSRC-RP-97-074, Westinghouse Savannah River Co., Aiken, SC (March, 1997).

12 R.F. Swingle, N.E. Bibler, A.A. Ekechukwu, “Data Report: Tank 19F NE Riser Zeolite Mound Sample Analysis,” U.S. DOE Report WSRC-RP-2001, 00410, Rev. 0, Westinghouse Savannah River Co., Aiken, SC (April, 2001). 
13 R.F. Swingle, "Characterization of the Tank 19F Closure Grab and Core Samples and the Tank 18F Dip Sample,” U.S. DOE Report WSRC-TR-200200107, Westinghouse Savannah River Co., Aiken, SC (March, 2002).

14 M.S. Hay, “Analysis of Tank 19F Solids by X-Ray Diffraction,” U.S. DOE Report SRT-LWP-97-111, Westinghouse Savannah River Co., Aiken, SC (September, 1997). U.S. DOE Report WSRC-TR-2002-00453, Rev. 0, Westinghouse Savannah River Co., Aiken, SC (September 30, 2002).

16 C.M. Jantzen, "Composition of Linde IE95 (AW500) Zeolite Fraction of Sludge,” U.S. DOE Report, DPST-88-623, E.I. duPont deNemours \& Co., Aiken, SC (June, 1988).

17 W. A. Deer, R. A. Howie, and J. Zussman, "Rock-Forming Minerals, Vol IV,” John Wiley \& Sons, Inc., New York, 435pp. (1963).

18 R. M. Barrer, J. W. Baynham, F. W. Bultitude, and W. M. Meier, "Hydrothermal Chemistry of the Silicates. Part V23I, Low-Temperature Crystal Growth of Aluminosilicates, and of Some Gallium and Germanium Analogues," 195-208 (1959).

19 B.D. Cullity, "Elements of X-Ray Diffraction,” Addison-Wesley Publ. Co., Reading, MA, 514pp (1967).

20 R.M. Barrer, "Hydrothermal Chemistry of Zeolites,” Academic Press, London, 360pp. (1982).

21 M.C. Barnes, J.A. Mensah, and A.R. Gerson, "The Mechanism of the Sodaliteto-Cancrinite Phase Transformation in Synthetic Spent Bayer Liquor,” Microporous and Mesoporous Materials, 31, 287-302 (1999).

22 A.R. Gerson and K. Zheng, "Bayer Process Plant Scale: Transformation of Sodalite to Cancrinite,” J. of Crystal Growth, 171, 209-218 (1997).

23 F. Liebau, Structural Chemistry of Silicates, Springer-Verlag, Berlin, 347pp. (1985).

24 D.R. Click, "Measured Coal Concentration in the Initial Tank Fifty One Sample By Thermogravimetric Analysis (TGA)," SRT-ADS-2003-0392 (July 22, 2003).

25 D.R. Click and C.J. Coleman, "Measured Coal Concentration in the First, Second, and Third Samples of Mixed Tank Seven Slurry Using Loss on 
Ignition (LOI) and Thermal Gravimetric Analysis (TGA),” SRT-ADS-20030005 (June 9, 2003).

26 J.L. Steimke, “Results from Tests of TFL Hydragard Loop,” U.S. DOE Report WSRC-TR-94-0598, Westinghouse Savannah River Co., Aiken, SC (March ,1995).

27 Z.H. Qureshi, “Mixing and Sampling of Sludge-Frit-CST Slurries,” U.S. DOE Report WSRC-TR-99-00309, Westinghouse Savannah River Co., Aiken, SC (September, 1999).

28 T.B. Edwards, Z.H. Qureshi, J.R. Harbour, and F.G. Smith, “Hydragard Sampling of Melter Feed Slurry Containing CST,” U.S. DOE Report WSRCTR-2000-00378, Westinghouse Savannah River Co., Aiken, SC (September 2000).

29 C.M. Jantzen, J.M. Pareizs, and T.B. Edwards “Thermodynamic Modeling of Deposition in Savannah River Site (SRS) Evaporators, Part IV. Incorporation of High Caustic Aluminosilicate Solubility Data” U.S. DOE Report WSRC-TR-2002-00330, Rev. 0, Westinghouse Savannah River Co., Aiken, SC (March 15, 2003).

30 D.K. Peeler, T.H. Lorier, D.F. Bickford, D.C. Witt, T.B. Edwards, K.G. Brown, I.A. Reamer, R.J. Workman, and J.D. Vienna, “Melt Rate Improvement for DWPF MB3: Frit Development and Model Assessment,” U.S. DOE Report WSRC-TR-2001-00131, Rev. 0 Westinghouse Savannah River Co., Aiken, SC (March 30, 2001).

31 C.M. Jantzen, "Relationship of Glass Composition to Glass Viscosity, Resistivity, Liquidus Temperature, and Durability: First Principles ProcessProduct Models for Vitrification of Nuclear Waste," Proceedings of the 5th International Symposium on Ceramics in Nuclear Waste Management, G.G. Wicks, D.F. Bickford, and R. Bunnell (Eds.), American Ceramic Society, Westerville, OH, 37-51 (1991).

32 K.G. Brown and C.M. Jantzen, “Relating Liquidus Temperature to Composition for Defense Waste Processing Facility (DWPF) Process Control,” U.S. DOE Report WSRC-TR-2001-00520, Westinghouse Savannah River Co., Aiken, SC (October 25, 2001).

33 K.G. Brown, and R. L. Postles, "SME Acceptability Determination for DWPF Process Control ,” U.S. DOE Report WSRC-TR-95-0364, Revision 3, Westinghouse Savannah River Company, Aiken, South Carolina (1996).

34 C.M. Jantzen, J.B. Pickett, K.G. Brown, T.B. Edwards, and D.C. Beam, "Process/Product Models for the Defense Waste Processing Facility (DWPF): Part I. Predicting Glass Durability from Composition Using a 
Thermodynamic Hydration Energy Reaction MOdel (THERMO),” US DOE Report WSRC-TR-93-0672, Westinghouse Savannah River Co., Aiken, SC, 464p. (September, 1995). 